\title{
SMALL POWER SYSTEMS STUDY
}

Volume 1: Study Results

Technical Summary Report

By

L. R. Sitney

May 31,1978

Work Performed Under Contract No. EY-76-C-03-1101-002

The Aerospace Corporation

Energy and Resources Division

Los Angeles, California

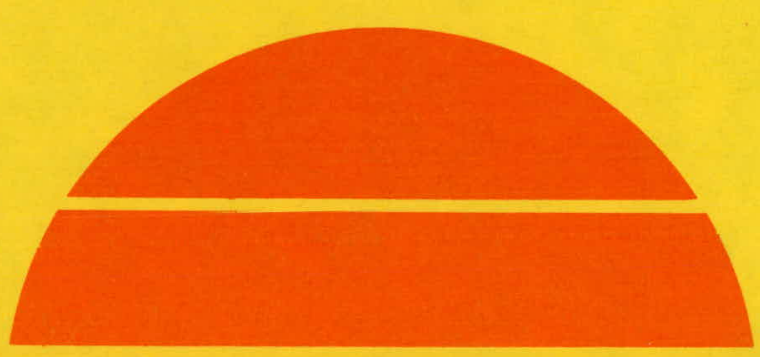

\section{U.S. Department of Energy}

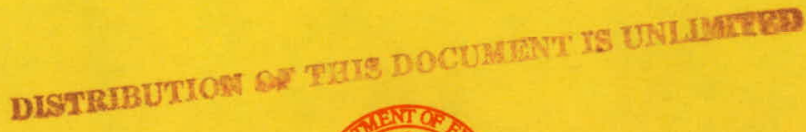




\section{DISCLAIMER}

This report was prepared as an account of work sponsored by an agency of the United States Government. Neither the United States Government nor any agency Thereof, nor any of their employees, makes any warranty, express or implied, or assumes any legal liability or responsibility for the accuracy, completeness, or usefulness of any information, apparatus, product, or process disclosed, or represents that its use would not infringe privately owned rights. Reference herein to any specific commercial product, process, or service by trade name, trademark, manufacturer, or otherwise does not necessarily constitute or imply its endorsement, recommendation, or favoring by the United States Government or any agency thereof. The views and opinions of authors expressed herein do not necessarily state or reflect those of the United States Government or any agency thereof. 


\section{DISCLAIMER}

Portions of this document may be illegible in electronic image products. Images are produced from the best available original document. 


\section{NOTICE}

Shis report was prepared as an account of work sponsored by the United States Government. Neither the United States nor the United States Department of Energy, nor any of their employees, nor any of their contractors, subcontractors, or their employees, makes any warranly, express or implied, or sssumes any legal liability or responsibility for the accuracy, completeness or usefulness of any information, apparatus, product or process disclosed, or represents that its use wuuld nut infringe privately owned rights.

This report has been reproduced directly from the best available copy.

Available from the National Technical Information Service, U. S. Department of Commerce, Springfield, Virginia 22161.

Price: Paper Copy $\$ 8.00$

Microfiche $\$ 3.00$ 
ATR-78(7693-05)-1(Vol.1)

Distribution Category UC-62b

SMALL POWER SYSTEMS STUDY

TECHNICAL SUMMARY REPORT

VOLUME I

STUDY RESULTS

This report was prepared as an atiount of work sponsored by the United States Covernment. Netment of

United States nor the Unir employees, nor any of their

Finergy. nor any of their ems or thelr enuployecs, makes

contractors, subcontractor, or the ar assumes any legal

any warranty, exposus for the securacy, completeness

liability or responsibilly for the acparatus, product or

or usefulness of any informant that its use would not

process disclosed, of represents
infringe privately owned rights.

31 May 1978

Prepared for

DIVISION OF CENTRAL SOLAR TECHNOLOGY

DEPARTMENT OF ENERGY

Washington, D.C. 20545

CONTRACT NO. EY-76-C-03-1101

Prepared by

Energy and Resources Division

THE AEROSPACE CORPORATION

Post Office Box 92957

Los Angeles, California 90009

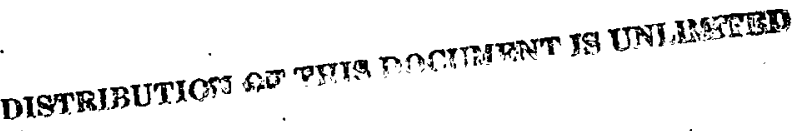




\section{ACKNOWLEDGEMENT}

The contributions of the following Members of the Technical Staff of The Aerospace Corporation to the Small Power Systems Study are hereby acknowledged:

\section{System Cost Analysis}

Allan:Forster: Central Recelver Cost Estimating Relationships and Foss1l-Fueled Steam-Electric Plant Data

Tony Mastor: Flnanclal dspects of Breakeven Cost Analysio

Miles Nesman: Fossil Fuel Cost Streams, and Diesel and Gas Turbine Cost and Performance Data

\section{Alaska Experiment}

Ron Sheahan

In addition, Alian Forster has particlpated in and contributed to the Study in an overall manner since its inception. Ron Sheahan has also contributed to the study in a variety of areas, including isolated utility systems and transmission costs, over most of the past year.

The efforts of Chriss Gamez in typing and preparing the art work for Volume I and of Micki Lewis in typing Volume II are gratefully acknowledged. The preparation of the Interim Report on this Study by Janet Rausch is belatedly acknowledged here. All three did an outstanding job.

This report was prepared by Dr. L. R. Sitney. 


\section{FOREWORD}

This is Vólume I of a two-volume Technical Summary Report, ATR-78(7693-05)-1, describing an Aerospace Corporation study of small power : systems performed for the Division of Central Solar Technology (formerly the Division of Solar Technology) of the Department of Energy: Volume II, "Inventory of Small Generating Units in U.S. Utility Systems", gives the number, size, and type of all fossll-fueled generating units up to $10 \mathrm{MH}$ in capacity by state and by utility system. As such, Volume II forms the utility data base for all analyses of small power systems in the U.S. which have been performed by The lerospace Corporation during the past year and which will be carried out during the coming year. 
CONTENTS

$\underline{\text { Page }}$

ACKNOWLEDGEMENT .

ii

FOREWORD

iii

1. INTRODUCTION $\ldots \ldots \ldots \ldots \ldots \ldots \ldots \ldots \ldots \ldots \ldots \ldots \ldots \ldots \ldots \ldots \ldots \ldots \ldots \ldots \ldots \ldots$ 1-1

2. SUMMARY...................................... 2-1

3. SMALL POWER SYSTEMS DATA BASE...................... 3-1

3.1 CHARACTERISTICS OF SMALL UTILITY SYSTEMS............. 3-2

3.1.1 Number of Small Utility and Power Systems........ 3-3

3.1 .2 Location of Small Power Units................ 3-9

3.1 .3 Ownership of Small Ut1lity Systems............ 3-11

3.1.4 Size Distribution of Small Generating Units....... 3-15

3.1.5 Interviews With Small Power System Users.......... 3-16

3.1.5.1 Arlzona Electric Power Cooperative, Inc., Benson, Arizona................... 3-23

3.1.5.2 Brazos Electric Power Cooperative, Inc., Waco, Texas...................... 3-24

3.1.5.3 Bridgeport Light and Power Dept., Br1dgeport, Texas.................. 3-25

3.1.5.4 Clayton Municipal Electric System, Clayton, New Mexico................ 3-25

3.1.5.5 Farmington Electric Utility, Farmington, New Mexico....................... 3-26

3.1.5.6 Hearne Municipal Electric System, Hearne, Texas.......................... 3-27 
CONTENTS (Cont'd)

$\underline{\text { Page }}$

3.1.5.7 Lea County Electric Cooperative, Inc.,

Lovington, New Mexico............... 3-27

3.1.5.8 Mesa City Utilities, Mesa, Arizona...... 3-28

3.1.5.9 Plains Electric Generation and

Transmission Cooperative, Inc.,

Albuquerque, New Mexico.............. 3-28

3.1.5.10 Raton Public Service Company, Raton,

New Mexico...................... 3-29

3.1.5.11 Safford Municipal Utilities, Safford,

Arizona.......................... 3-29

3.1.5.12 Swisher Electric Cooperative, Inc.,

Tulia, Texas................... 3-30

3.1.5.13 Tucumcar1 Light and Power Dept.,

Tucumcar1, New Mexico.............. 3-30

3.1.5.14 Tulia Municipal Light and Water Dept.,

Tulia, Texas.................... 3-31

3.2 CHARACTERISTICS OF SMALL SOLAR THERMAL POWER SYSTEMS...... 3-32

3.2.1 Central Recelver Power Systems................ 3-33

3.2.2 Distributed Collector Power Systems............. 3-36

3.3 CHARACTERISTICS OF SMALL FOSSIL-FUELED POWER PLANTS....... 3-41

3.3.1 Characteristics of Small Steam-Electric Plants..... 3-44

3.3.2 Characteristics of Diesel Generator Units......... 3-49

3.3.2.1 Age........................ 3-49

3.3.2.2 Fuel......................... 3-50

3.3.2.3 : Performance and Cost............... 3-51

3.3.3 Characterist1cs of Gas Turbines............... 3-53 
CONTENTS (Cont'd)

Page.

3.4 InSOLATION DATA............................ 3-54

3.5 FUEL cosTS.............................. 3-56

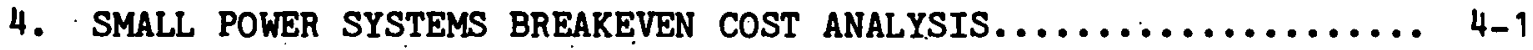

4.1 InTRODUCTION.................................. $4-1$

4.2 CASES ANALYZED ............................. $4-3$

4.3 METHODOLOGY USED IN BREAKEVEN COST ANALISIS............. 4-13

4.3.1 Cost Analysis by Means of the ERDA/EPRI

Methodology................................ 4-13

4.3.1.1 Cost of Capital................ 4-15

4.3.1.2 Capital Recovery Factor............. 4-15

4.3.1.3 Annualized Fixed Charge Rate.......... 4-16

4.3.1.4 Present Value of Capital Investment..... 4-16

4.3.1.5 Present Value of Fuel Cost.......... 4-17

4.3.1.6 Present Value of Other Operations and Maintenance Costs.................. 4-17

4.3.1.7 Annualized System Cost.............. 4-18

4.3.1.8, Levelized System Cost.............. 4-18

4.3.1.9 Sample Calculation............... 4-19

4.3 .2 Calculation of Fuel Savings................ 4-23

4.4 RESULTS OF THE BREAKEVEN COST ANALYSIS.............. 4-25

4.4.1 Municipal Utility Systems................... 4-27

4.4.2 Investor-Owned Ut111ty Systems............... 4-27

4.4 .3 Discussion of Results..................... 4-27 
CONTENTS (Cont'd)

$\underline{\text { Page }}$

4.4.3.1 Effect of Insolation Level........... 4-38

4.4.3.2 Effect of Type of Ownership.......... 4-41

4.4.3.3 Effect of Plant S1ze............. 4-43

4.4.3.4 Effect of Inflation..................4-46

4.4.3.5 Effect of Hellostat Costs............. 4-46

4.4.3.6 Effect of Solar Plant Startup Date...... 4-50

4.4.4. Observations on the Breakeven Cost Analysis....... 4-51

5. DEPARTMENT OF DEFENSE APPLICATIONS.................... 5-1

5.1 SOLAR INSOLATION DATA........................ 5-3

5.2 OPERATIONAL CONSIDERATIONS.................... 5-10

5.3 FUTURE ACTIVITY............................ $5-13$

6. ALASKA EXPERIMENT ............................. 6 .

6.1 BACKGROUND $\ldots \ldots \ldots \ldots \ldots \ldots \ldots \ldots \ldots \ldots \ldots \ldots \ldots \ldots \ldots \ldots \ldots \ldots \ldots . \ldots \ldots$

6.2 ALASKA AND ITS CONSTRAINTS...................... $6-2$

6.2 .1 Rural Interior Alaska.................... 6-4

6.2 .2 Insolation In Central Alaska................ 6-5

6.3 SUMMAR................................... $6-7$

7. REMOTE APPLICATIONS. .......................... 7-1

REFERENCES $\ldots \ldots \ldots \ldots \ldots \ldots \ldots \ldots \ldots \ldots \ldots \ldots \ldots \ldots \ldots \ldots \ldots \ldots \ldots \ldots \ldots \ldots \ldots$

vii 
TABLES

Page

3-1. Number of Utility Systems With Small ( $\leqslant 10 \mathrm{MW}$ ) Power Units.................................... 3-5

3-2. Summary of Small ( $\leqslant 10 \mathrm{MW})$ Power Units in the United States.............................. 3-7

3-3. States With Highest Percentages of Small Power Units.... 3-10

3-4. Ownership of Small. Utility Systems in the United States.. 3-13

3-5. Number of Small Steam/Gas Turbines as a Function of Generating Capacity.......................... 3-17

3-6. Number of Small Diesel Generators as a Function of Generating Capacity................................. 3-19

3-7. Design Characteristics of $1.0 \mathrm{MW}_{\mathrm{e}}$ Power Plant........... 3-35

3-8. Cost Model (FSP 058) for Central Recelver Power Plants (Average Plant Cost).......................... 3-37

3-9. Energy Cost Breakdown, $10 \mathrm{MW}_{\mathrm{e}}$ Plant............... 3-42

3-10. Energy Cost Breakdown, $100 \mathrm{MW}_{\mathrm{e}}$ Plant............... 3-42

3-11. Small Steam-Electric Plant Data.................. 3-45

3-12. Locations and Insolation Values for Breakeven Analyses... 3-54

3-13. Prices of No. 2 Fuel 011 Deliveries to Steam-Electric Plants.................................... 3-57

3-14. Natural Gas Prices in "Sun Belt" States.............. 3-59

3-15. Energy Prices in California.................... 3-60

3-16. Energy Prices in Texas........................... 3-61

3-17. Energy Prices in New Mexico.................... 3-62

3-18. Energy Prices in Arizona...................... 3-63

3-19. Energy Prices in Nevada...................... 3-64

4-1. Variables Used in Initial Breakeven Cost Analysis...... 4-5 
TABLES (Cont'd)

Page

4-2. Central Receiver Cost Data for Breakeven Analysis...... 4-7

4-3. Steam-Electric Cost and Performance Data for Breakeven Analysis................................. 4-7

4-4. Diesel Generator Cost and Performance Data for Breakeven Analysis.................................... 4-7

4-5. Operations and Maintenance Costs for Breakeven Analysis.. 4-8

4-6. Financial Factors Used in Breakeven Cost Analysis...... 4-10

4-7. Forecast Natural Gas and No. 2 Fuel Oil Prices for 1985-2015.................................. $4-11$

4-8. Matrix of Cases for Breakeven Cost Analysis.......... 4-25

4-9. Levelized Costs for Municipally-Owned Power Plants in California................................. 4-28

4-10. Levelized Costs for Municipally-Owned Power Plants in Texas..................................... 4-29

4-11. Levelized Costs for Municipally-Owned Power Plants in New Mexico................................ 4-30

4--12. Levelized Costs for Municipally-Owned Power Plants in Arizona.................................. 4-31

4-13. Levelized Costs for Municipally-Owned Power Plants in Nevada................................... 4-... 42

4-14. Levelized Costs for Investor-Owned Power Plants in California................................. 4-33

4-15. Levelized Costs for Investor-0wned Power Plants in Texas..................................... 4-34

4-16. Levelized Costs for Investor-Owned Power Plants in New Mexico................................ 4-35

4-17. Levelized Costs for Investor-Owned Power Plants in

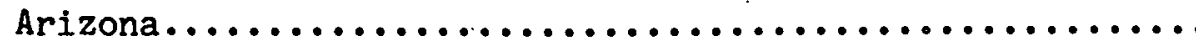

4-18. Levelized Costs for Investor-Owned Power Plants in Nevada..................................... 


\section{TABLES (Cont'd)}

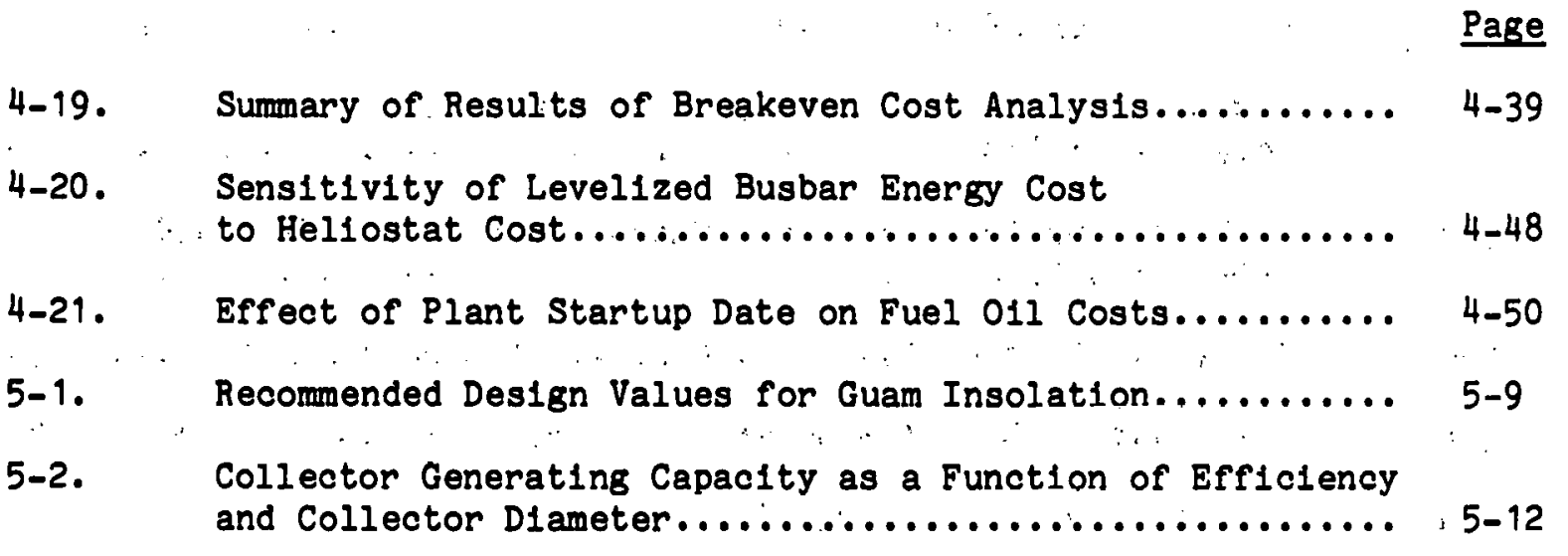


3-1. Distribution of Small Power Units................ 3-12

3-2. McDonnell Douglas Design for $10 \mathrm{MW}$ Central Receiver

Solar Power Plant............................ 3-34

3-3. Central Recelver Costs as a Function of Power Level and Production Quantity........................... 3-36

3-4. Parabolic Dish Collector With Steam Transport System.... 3-40

3-5. Parabolic Dish Collector With Electric Transport System.. 3-40

3-6. Effect of Plant Size and.Type on Energy Cost.......... 3-41

3-7. Costs of Coal-Fired Steam-Electric Plants........... 3-46

3-8. Costs of 0il-Fired Steam-Electric Plants............ 3-46

3-9. Heat Rates for Steam Plants and Diesel Generators....... 3-48

3-10. Capital Costs of Diesel Generators................. 3-52

3-11. Gas Turbine Costs........................... 3-53

4-1. Solar Repowering Concept...................... 4-4

4-2. Effect of Inflation Rate on 30-Year Costs............ 4-12

4-3. ERDA/EPRI Cost Methodology Flow................. 4-14

4-4. Computer Printout of ERDA/EPRI Calculations for $10 \mathrm{MWe}$

Solar Thermal Power Plant in Replacement Mode......... 4-22

4-5. Effect of Location on Cost-Effectiveness............ 4-40

4-6. Levelized Energy Costs and Cost-Effectiveness as a

Function of Type of Ownership................... 4-42

4-7. Effect of Type of Ownership on Cost of Service........ 4-44

4-8. Effect of Plant Size on Levelized Energy Costs......... 4-45

4-9. Effect of Inflation on Levelized Energy Costs.......... 4-47

4-10. Effect of Heliostat Costs on Levelized Energy Costs..... 4-49 
FIGURES (Cont'd)

Page

5-1. Location of Northwest Guam Air Force Base............ 5-4

5-2. Northwest Guam Air Force Base................. 5-5

5-3. Direct and Global Insolation Estimates for Guam......... 5-9

6-1. Hours of Daylight......................... 6-2

6-2. Fairbanks and Albuquerque Direct Insolation Upper Limits. 6-6

6-3. Comparison of Albuquerque and Fairbanks Direct.

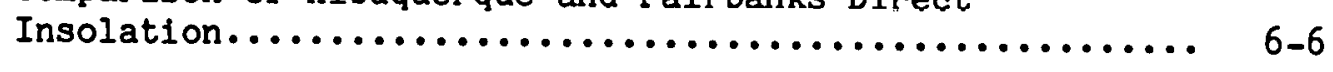

xii 


\section{INTRODUCTION}

The Division of Solar Technology (now the Division of Central Solar Technology) of the Department of Energy (DST/DOE) is currently examining the market potential of a number of dispersed solar energy systems, including the small $(\leqslant 10 \mathrm{MW})$ solar thermal power system. Smal.l fossil-fueled generating units in the United States utility system, (i.e., investor-owned, municipal, and cooperatives) have a current capacity of approximately $8000 \mathrm{MW}$ or about 1.5 percent of the total U.S. electrical capacity, and provide a large potential market for small solar thermal power systems.

Many of these small generating units have been burning natural gas which historically has been cheap and abundant, as well as environmentally desirable. Current Government policy with respect to the use of natural gas for the production of electrical power, combined with a rapidly, increasing cost and a diminishing supply of this fuel, are forcing a nationwide curtafiment of the use of natural gas in the utility industry. A few of the small municipal utility systems have actually closed down and sold their generating units. Many more have placed their generators in a standby mode and are purchasing all of their power from a large utility system. A large number of small utility systems, primarily municipal, are now restricting their power generation to all or a portion of their peak power requirements and buying the remainder of their power from a large utility system. Although they have restricted their generating capability, all three types of utility systems are continuing to distribute power to their customers. Wherever possible, all of the utility systems which burn natural gas are converting to the use of No. 2 diesel fuel or dual fuel, i.e., gas or oil.

The Small Power Systems Study has as its objective the determination of conditions under which smaj.l $\left(\leqslant 10 \mathrm{MW}_{e}\right)$ solar thermal 
power units can provide cost-effective electrical power to a variety of users. Potential users, in addition to the utility systems, include Department of Defense installations and applications, remote mining and/or lumbering operations, and other industrial power systems. with and without cogeneration. Work to date has concentrated primarily on the utility systems, but the other applications will be examined in the next year.

Most of the past year's activity has, of necessity, been devoted to the collection of cost and performance data on small fossil-fueled and solar thermal power systems and on the utility systems which use small generating units. The acquisition of data for small fossil-fueled steam generating units was originally considered to be especially jmportant because these units, in principal, represented one of the main alternatives to solar units. Lack of cost data for small fossil-fueled power systems precluded cost comparisons with solar thermal power systems in the Interim Report on the Small Power Systems Study (Reference 1). Acquisition of the data has turned out to be difficult because small steam plants are no longer being installed by utility systems in the United States, although a limited number of such units is being produced for industrial use. Thus, while sufficient data have now been acquj.red to make cost comparisons between small solar thermal and fossil-fueled steam plants in utilities, the comparisons are largely academic since future buys of generating equipment by utility systems will not include small fossil-fueled steam-electric plants.

Using the data on small generating units, both solar and fossil-fueled, an initial breakeven cost analysis has been carried out for small solar thermal power systems in the repowering and replacement modes in utility systems in five southwestern states. The results of these initial analyses, which are reported in Section 4, will be used to provide guidance for more detalled analyses of the market potentiaj. for small solar thermal power systems during the FY 1978-1979 follow-on contract. 
Section 2 of this volume summarizes the first year's results on the Small Power Systems Study. Section 3 describes the data base used for the breakeven cost analysts discussed in Section 4. Section 3 contains information on both small. $(\leqslant 10 \mathrm{MW})$ generating units and the utility systems using them as, well. as data on fossil fuel costs, sol.ar plant costs; and solar insolation values. The results of a survey.. of Department of Defense (DOD) worldwide electrical generating : capacity at its military bases and on a potential DOD application are presented in Section 5. Information on a potential smalli solar power system experiment in the interior of Alaska is given in Section 6. Section 7 contains a limited amount of information on a remote application. which would provide power for...a large open pit copper mine.

Volume II of this Technical Summary Report contains an inventory, by state, of the small. $\left(\leqslant 10 \mathrm{MW}_{e}\right)$ generating units in. the U.S. ut111ty system. 


\section{SUMMARY}

This report presents the results of two data gathering activities and two analyses carried out on the Small Power Systems Study in the 15-month period from March 1977 through May 1978. The two data gathering tasks were:

- Compilation of an inventory of the small generating units in the U.S. utility system

- Development of a data base on the cost and performance of small $\left(\leqslant 10 \mathrm{MW}_{\mathrm{e}}\right)$ solar thermal and conventional power systems

Analyses were conducted in the following areas:

- Breakeven cost analysis of small solar thermal power systems

- Examination of Guam as a possible site for a Department of Defense experimental solar thermal power system

In addition, cursory examinations were carried out for a possible small experimental solar thermal power system in central Alaska and for a potential application to provide power to remote mines in the southwestern United States.

The inventory of small generating units in the U.S. was accomplished by listing all -small fossil-fueled generating units contained in either or both the 1976-1977 Electrical World Directory of Electric Utilities (Reference 4) and the Federal Energy Administration inventory of all units in the U.S. (Reference 5). Discrepancies between 
these two sources were resolved by telephone calls to the ut1lity systems involved. The complete inventory of small power systems is given. In Volume II of this report, which lists each small generating unit by size, number, type (1.e., steam-electric, diesel, or gas turbine) in each municipal, investor-owned, and other (e.8.,. cooperatives, universities, and government-operated) ut1lity system in each state. Section 3.1 of this volume surnmarizes the results of the inventory of small fossilfueled power systems.

There are 3869 small, fossil-fueled generating units in the 50 states. with a total generating capacity of 7894 megawatts. of these units, 581 are steam-electric plants, 3243 are diesel generators, and 45 are gas turbines. The average generating capacity of the steam-electric plants and the gas turbines is approximately five megawatts, while the average capacity of the diesels is fust under 1.5 megawatts. These generating units are operated by 716 utility systems; 109 of these are investor- owned, 545 are municipal systems, and 62 are others, primarily cooperatives. Approximately half ( 49.6 percent) of all these units are located in the states of Iowa, Minnesota, Kansas, Nebraska, Michigan, and Missour1. The eight southwestern states with the highest solar insolation levels have only 12.6 percent of the small. fossil-fueled power units in the U.s.

Sections 3.2 and 3.3 characterize the small, solar thermal and small conventional power system data bases, respectively. Section 3.2 contains cost data on , both the central receiver- and point focus distributed collector-type of solar thermal power systems. Most of the data, however, are for the central recelver solar thermal power system, including cost estimating relationships developed by The Aerospace Corporation for the $1-10 \mathrm{MW}$ range from McDonnell Douglas data (Reference 2). Section 3.3. contains both cost and performance data on small conventional steam-electric plants, diesel generators, and. gas 
turbines. The primary difficulty with both data bases, with the exception of the data for diesel generators, is that the raw data were for power plants larger than $10 \mathrm{MW}$ in capacity whereas this Study is constrained to units no larger than $10 \mathrm{MW}$ in capacity. The accuracy of the extrapolation of the cost data for both types of power systems into the 1-10 MW range is subject to question. The validity of the solar thermal power plant data in this range should be reexamined and improved, wherever possible, during the coming year.

Insolation data used in the breakeven cost analysis are contained in section 3.4. The direct-normal insolation values are the revised National Oceanographic and Atmospheric Administration insolation values, Data Base II, modified by the new Aerospace Corporation correlations: These revised direct-normal insolation values are lower for the following states than the values used in Aerospace Corporation mission analyses prior to FY 1978 by these percentages: California-13\%, Arizona and Texas-14\%, New Mexico-15\%, and Nevada-17\%.

Fuel price projections for a number of fuels in the 1985-2015 time period were developed by Sherman H. Clark Associates in support of The Aerospace Corporation's Solar Total Energy Systems Study (Reference 7). Price projections are given for natural gas and for No. 2 fuel oil for the five southwestern states which were analyzed in the breakeven cost analysis, i.e., Arizona, California, Nevada, New Mexico, and Texas. In general, the values for each type of fuel agree to within a few percent in all five states after 1990 and, therefore do not have a major impact on the results of the breakeven cost analysis for these five states.

The breakeven cost analysis for small utility systems, which is described in section 4, considered 256 cases. The solar thermal power plants were operated in both the repowering and replacement modes without 
any thermal storage, starting in 1985. In the repowering mode, the solar power system provides thermal energy during periods of acceptable insolation to the steam turbine of a conventional steam-electric plant (as well as to a thermal storage system, normally). Whenever the insolation is too low, the steam-electric plant generates its own power by burning fossil fuel (or operates off the thermal energy stored by the solar power system). In the repowering mode, the solar power system costs include the solar collectors (hellostats), receivers, controls, and associated piping and valves. In the replacement mode, the power conversion equipment, i.e., turbine generators, must also be purchased for the solar thermal power system. The replacement mode must be used with diesel generators, whereas either mode can conceivably be used with steam-electric plants (subject to engineering constraints not yet fully understood, such as achieving the proper steam quality from the solar operation in a cost-effective manner which may involve burning a small of amount of fossil fuel).

The following variables were included in addition to the two operational modes discussed above: inflation rate ( 0 and 3.5 percent), type of ownership (municipal and investor-owned) to determine the effect of the cost of capital, plant size ( $1 \mathrm{MW}_{e}$ and $\left.10 \mathrm{MW}\right)$, to examine the effect of economy of scale, No. 2 fuel 011 and natural gas as fossil fuels, and the five previously mentioned southwestern states to determine the effect of the solar insolation level. In addition, heliostat costs were varied for California from the baseline value of $\$ 70 / \mathrm{m}^{2}$ to $\$ 50 / \mathrm{m}^{2}, \$ 140 / \mathrm{m}^{2}$, and $\$ 210 / \mathrm{m}^{2}$ to determine the effect of heliostat costs on the analysis. Finally, the 1985 startup date for the solar thermal power plants was delayed to the year 2000 in Nevada, the southwestern state with the lowest solar insolation value used in the analysis, to determine the effect of higher fuel prices on the results of the analysis. 
The ERDA/EPRI cost methodology (Reference 12) was selected for the breakeven cost analysis because: (1) the analyses would be relatable to analyses made on other solar thermal power system studies by other contractors using the same methodology and (2) other Aerospace Corporation financial models are too sophisticated to justify their-use on the initial breakeven cost analyses.

The following obocrvations can be lllde regarding the results of the initial breakeven cost analysis which examined small utility systems with a 1985 startup date for the solar thermal power systems.

The results of the analysis should be treated as qualitative rather than quantitative at this time because of uncertainties in the accuracy of the cost data in the $1-10 \mathrm{MW}_{\mathrm{e}}$ range.

- The Sherman Clark fuel price projections for the 1985-2000 time period indicate what the fuel savings would be if a solar thermal power plant were to be used instead of a conventional plant and, therefore, can serve to establish an upper limit for the cost of a solar thermal power plant which would be cost-effective. The solar thermal power plant costs used in this analysis are valid only for central receiver-type solar plants and no conclusions can or should be drawn regarding the costs of distributed collector-type solar power plants in the 1-10 $\mathrm{MW}_{e}$ power range.

Economy of scale has the largest effect of any of the variables examined in the analysis. Levelized busbar energy costs are approximately 2.2 times as great for a $1 \mathrm{MW}$ plant as for a $10 \mathrm{MWe}$ plant, regardless of type of ownership, rate of inflation, location, or heliostat cost. With the exception of California and Texas for a municipal utility, a $1 \mathrm{MW}$ solar plant is not cost-effective in any of the five sun belt states in either the repowering or replacement modes compared to an oil-fired steam-electric plant. On the other hand, both municipally- and investor-owned $10 \mathrm{MW}$ solar thermal power plants are cost-effective in all five southwestern states in both operating modes.

- The operational mode of the solar thermal power plant is the next most important factor in the breakeven cost 
analysis. A plant in the repowering mode is always more cost-effective than in the replacement mode, primarily because capital costs are significantly lower in the former case. A solar thermal plant in the repowering mode without thermal storage is about half as sensitive to decreases in the solar insolation level as a plant in the replacement mode.

Diesel generators are about twice as cost-effective as either the solar or conventional steam-electric plants at $10 \mathrm{MW}_{\mathrm{e}}$ and almost four times as cost-effective at $1 \mathrm{MW}_{\mathrm{e}}$ in the five southwestern states.

- Variations in the direct-normal solar insolation from state-to-state (or within regions of a state) have a greater effect on the relative cost-effectiveness of a solar thermal power system than geographical variations in the fuel price in the five states analyzed.

- Levelized busbar energy costs for a municipal solar plant are about 20 percent lower than for an investor-owned solar plant; thus, it will be possible for a municipal utility system to introduce a solar thermal power plant into its system under conditions which would be unfavorable for an investor-owned system. In addition, because of this condition, the introduction of solar power plants by municipal utility systems could serve as the entering wedge to drive down the cost of solar thermal power plants for the remainder of the utility industry.

Inflation affccto tho levelized onergy sost. of nnnventional power plants more than solar thermal power plants because the price of fossil fuel is subject to inflation throughout the entire 30-year life of the conventional plant. For the financial factors used in this analysis, the levelized value of the capital cost of a power plant is increased by about 35 percent by inflation whereas the fuel and 0\&M levelized costs increase by approximately 50 percent.

Heliostat costs do not have a major impact on the results of the breakeven cost analysis because they represent a relatively minor portion $(11$ and 20 percent, respectively, for $1 \mathrm{MW}_{\mathrm{e}}$ and $10 \mathrm{MW}$ plants in the replacement mode and 20 and 36 percent, respectively, in the repowering mode) of the solar plant costs. However, as the insolation decreases, the cost-effectiveness of a solar power plant is more sensitive to increases in the cost of heliostats. Also, a solar power plant in the replacement mode is much 
more sensitive to changes in heliostat costs than a plant in the repowering mode; a $10 \mathrm{MWe}$ plant is less sensitive to increases in hellostat costs than a $1 \mathrm{MWe}$ plant; and an investor-owned plant is more sensitive than a municlpal plant.

Department of Defense (DOD) ut1lity, system operations were examined in an attempt to identify a second application for an experimental solar thermal power system. At the present time, worldwide, no Air Force bases operate thelr own electrical utility systems, and only one Army base (Fort Greely, Alaska) and 12. Navy bases operate ut1lity systems. Most of the Navy bases produce process heat as part of the utility operation. As a result of the small number of DOD utility systems, it appeared that such systems did not represent a generic class of applications for solar thermal power systems.

An attempt was then made to identify a remote DOD installation In the Pacific or Caribbean areas which had its own generating capacity In the 100-1000 $\mathrm{kW}$ e range. The remote location was selected with the expectation that fuel costs would be very high, but it was learned that the DOD establishes a uniform worldwide price for each type of fuel annually. Thus, Guam, which was being examined for an experimental system at the Air Force's Northwest Guam Air Force Base, pays only $\$ 0.43$ per gallon for diesel fuel used in the diesel generators at the Air Force Base. In addition, subjective comments by Air Force personnel on the climatic conditions on Guam led to expectations that the insolation level would be favorable on Guam. 'However, analyses of cloud cover data for Guam by Aerospace Corporation specialists led to the conclusion that the annualized average direct daily insolation was only about 4.1 $\mathrm{kWh} / \mathrm{m}^{2} /$ day (equivalent to that of Miami), which is relatively low. Even though land is available for an experimental $500 \mathrm{~kW}_{\mathrm{e}}$ solar thermal power system installation at Northwest Guam Air Force Base, the 
combination of low fuel prices and mediocre insolation tend to make Guam unattractive as the site for such an application. Puerto Rico and Guantanamo Bay, Cuba, appear to have solar insolation values which are very similar to Guam and, thus, are subject to the same limitations as Guam.

Alaska was examined as a potential site for an experimental solar thermal power system in the $10 \mathrm{~kW}$ range because of the large number of isolated villages in that state. Insolation data for Fairbanks indicated that insolation in the interior of Alaska is almost as high as for Albuquerque during five months of the year. When the long hours of daylight during this period are taken into consideration, Alaska appears attractive for an experimental solar power system. In addition, since diesel fuel has to be brought into the remote villages in the interior of Alaska during the summer, sometimes by air, the cost of electricity per kilowatt-hour in some of these villages is in the $\$ 0.32-0.50$ range. At that price, solar power would look very attractive, even though it could provide power for only part of the year.

Remote, open pit copper mining operations in the Southwest were also examined cursorily as a potential application for solar thermal power systems. Discussions with state resource agencies, a mining company, and a major utility indicated that the application was not a good one for a variety of reasons. First, there are only a limited number of major mines of all types under development at any one time. Once testing indicates that the ore reserves are sufficient for at least 25 years of operation and that it would be profitable to develop the mine, transmission lines are brought into the site. These lines normally will not exceed 25 miles in length anywhere in the Southwest, and so are not prohibitive in cost. Finally, at least for open pit copper mines, the mining companies recover the cost of the investment in approximately 6.5 years, which is too short a period to be able to amortize the cost of a solar thermal power system.

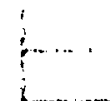




\section{SMALL POWER SYSTEMS DATA BASE}

The development of an adequate data base to support inalyses for the Small Power Systems Study has been the primary goal of the Study during the past year. Sufficient data have now been acestimulated to permit meaningful analyses to be carried out for utilfty systems applications. Data on industrial power generation have béện obtained from the Federal Energy Regulatory Commission (FERC) from their Form and Form $12 \mathrm{C}$ industrial files. However, these data hust be supplemented with additional information on the power generation patterns and possible cogeneration practices of various industries which generate their om power before any useful analyses on industrial applications can be performed.

Cost and performance Information on both the central recelver and point focusing distributed collector types of solar thermal power systems were obtained from studies by McDonnell Douglas (Reference 2) and the Jet Propulsion Laboratory (JPL) (Reference 3), respectively. Comparable data for small fossil-fueled electrical generating units were not avallable when the Interim Report for the Small Power Systems Study was published. in January 1978; as a consequence, it was impossible to conduct cost comparisons of small solar thermal and conventionally fueleft power systems at that time. A limited, but adequate, data base for small coal- and oil-fired steam plants has been constructed from Federal Power Commission (now FERC) data on such plants built in the late 1950s and 1960s. Data on diesel generators and gas turbines are readily available and have been incorporated into the data base.

Insolation data used in this Study were taken from The

Aerospace Corporation's insolation data base, which is used to support all of the solar power studies conducted by the Corporation. Additional 
Insolation data were acquired for Andersen A1r Force Base on Guam and for Fairbanks, Alaska, for use in the special analyses reported in Sections 5 and 6 , respectively.

The data base used in the Small. Power Systems Study is described in the remainder of this section.

3.1 CHARACTERISTICS OF SMALL UTILITY SYSTEMS

A small utility system, as defined for the purposes of this Study, is any utility system which has individual generating units with no more than $10 \mathrm{MW}$ capacity. An inventory of all (716) of the small utility systems in the United States is given in Table I of Volume II of this Technical Summary Report, along with data on the type (1.e., steam turbine, diesel generator, or gas turbine) of generating unit and the sizes and numbers of each type. Four of these utility systems operate in more than one state, which accounts for the 722 utility systems listed in Table III, Volume II. A summary of the data for each state is presented in Table II, Volume II, for the total number of units and the total generating capacity of each of the three types of units. Table III summarizes the data, by state, for the number of utility systems, including standby utility systems, with each type of unit.

The data on small utilities contained in Volume II comprise the data base on existing generation capacity for use in this study. Growth in capacity and how it will. be met in 1985 and beyond will be analyzed during the follow-on study over the next year. The inventory of small utilities was initially generated in response to a request by the Division of Solar Technology's Assistant Director for Thermal Power Systems for information on the number of small $\left(\leqslant 10 \mathrm{MW}_{e}\right)$ steam turbine generating units in the Southwest and the remainder of the country and on. their total generating capacity. The request was almost immediately 
expanded to include all small fossil-fueled generating units. At that time, the inventory was simply an intermediate step in the development of the data desired by DST. The data in the inventory were obtained by listing each small utility system and its equipment, as show in the 1975-1977 (85th Edition) Electrical World Directory of Electrial Utilities (Reference 4 ).

During the compilation of these data, a member of The Aerospace Corporation's technical staff pointed out that the Federal Energy Administration (FFA) had recently published an inventory of power plants in the United States (Reference 5) which did not agree completely with the Electrical World Directory. There was insurficient time

- availahle to compare the two sources of data on smajll power systems prior to the submittal of the response to DST. However, once the response mad been prepared, it appeared worthwhile to compare the two sources; to try. to resolve the differences, and then to document the correct data. The: differences were of two types: (1) the listing of a utility system in only one of the two sources and (2) variations in the numbers of generating units or their sizes between the two sources. The discrepancies were resolved by calling each of the utility systems with disparate data and determining the actual status of the utility and its equipment. The only utility systems not contacted were those in Aliaska and Hawaii. In the case of Alaska, Reference 5 is probably the more accurate. In Hawall, the two sources agree very closely. In general, Reference 4 is probably more correct than Reference 5, which does not jnclude a large number of sma!l. utility systems in several midwestern states.

3.1.1 Number of Small Utility and Power Systems

As indicated earlier, there are 716 utility systems in the. United States with generating units no larger than $10 \mathrm{MW}$ in capacity. 
Table 3-1 shows the number of utility systems in each state which operate each of the three types of fossil-fueled generating units. However, it should be noted that some of the utility systems operate more than one type of generating unit, resulting in a total number of utility systems which is less than the sum of the individual numbers of utility systems. For example, in Alaska, two of the utilities operate two types of equipment and one operates all three types. The number in parentheses indicates the number of utility systems on a standby generating basis in the varjous states. Two of the 50 standby systems have both steam turbine and diesel units on standby, resulting in the total of 52 systems shown in the table. Table 3-2 shows the number of generating units of each type in each state; the number of standby units, which is given in parentheses, is included in the state totals. Table 3-2 also shows the percentage of each type of generating unit in each state, as well as the percentage of total generating units in the Nation; all percentages are based upon the total number of generating units, including standby units.

The number of small municipal utility systems on standby appears to be increasing with the passage of time as natural gas and oil prices increase and as the assured supply of natural gas for utility systems is curtalled. Moreover, in Oklahoma, a large number of municipal utility systems operate only in the late Spring and Summer to provide peak power for irrigation. During these months, the Oklahoma utility systems have had no difficulty in obtaining natural gas for their diesel

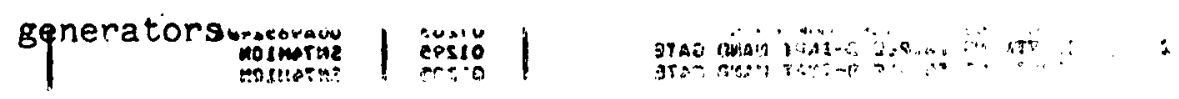

Although no small municipal utility systems or cooperatives have actually teamed together or with investor-owned utility companies to build large coal-fired steam plants capable of providing power to the conglomerate, discussions are proceeding among several different groups of utilities interested in teaming to produce power economically. In Arizona, New Mexico, and Pennsylvania, state laws currently prevent joint 
Table 3-1. Number of Utility Systems With Small ( $\left.\leqslant 10 \mathrm{MW}_{\mathbf{e}}\right)$ Power Units

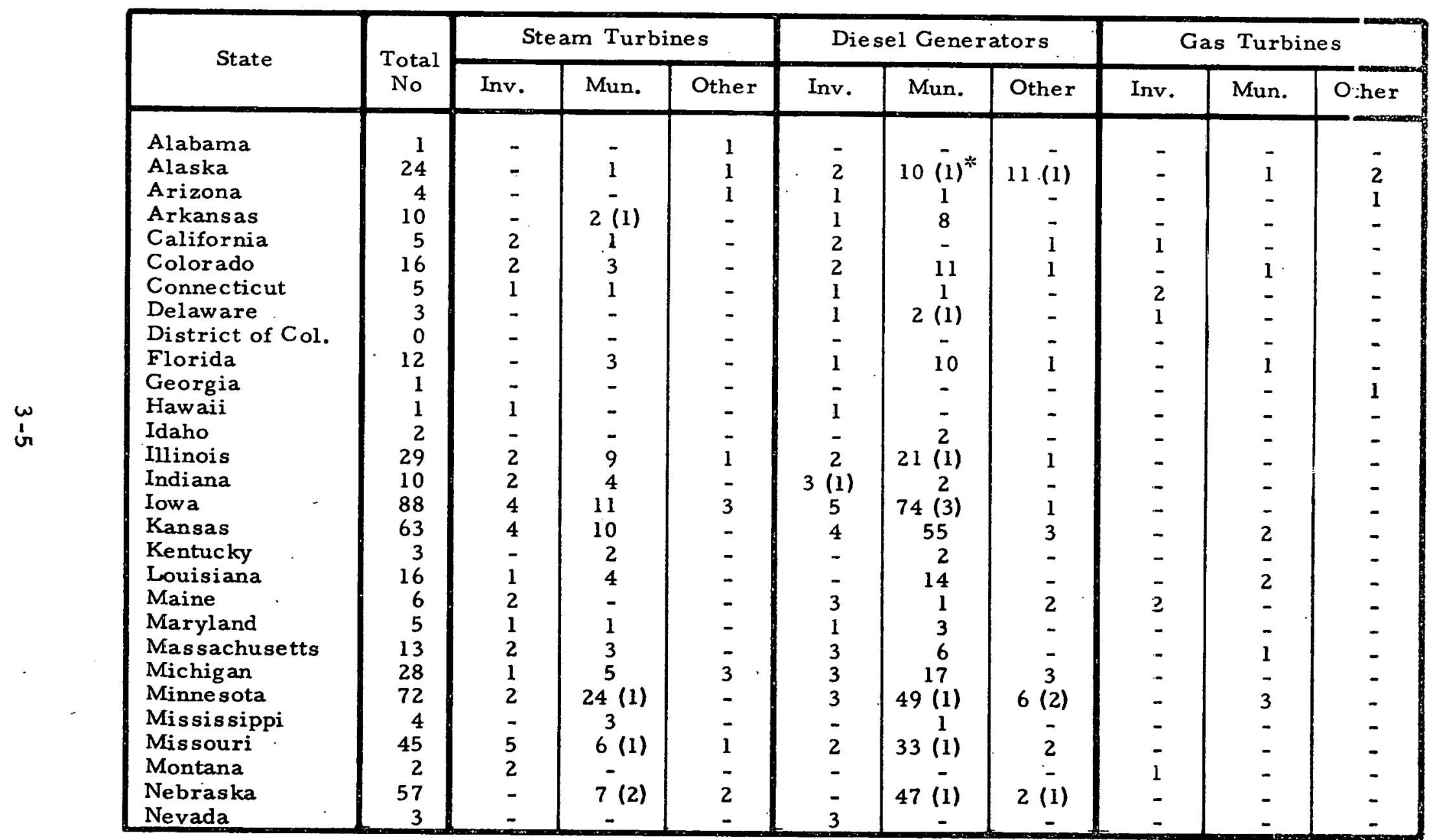

* Number in parentheses denotes number of utility systems in standby status. 
Table 3-1. Number of Utility Systems With Small ( $\left.\leqslant 10 \mathrm{MW}_{\mathbf{e}}\right)$ Power Units (Cont'd).

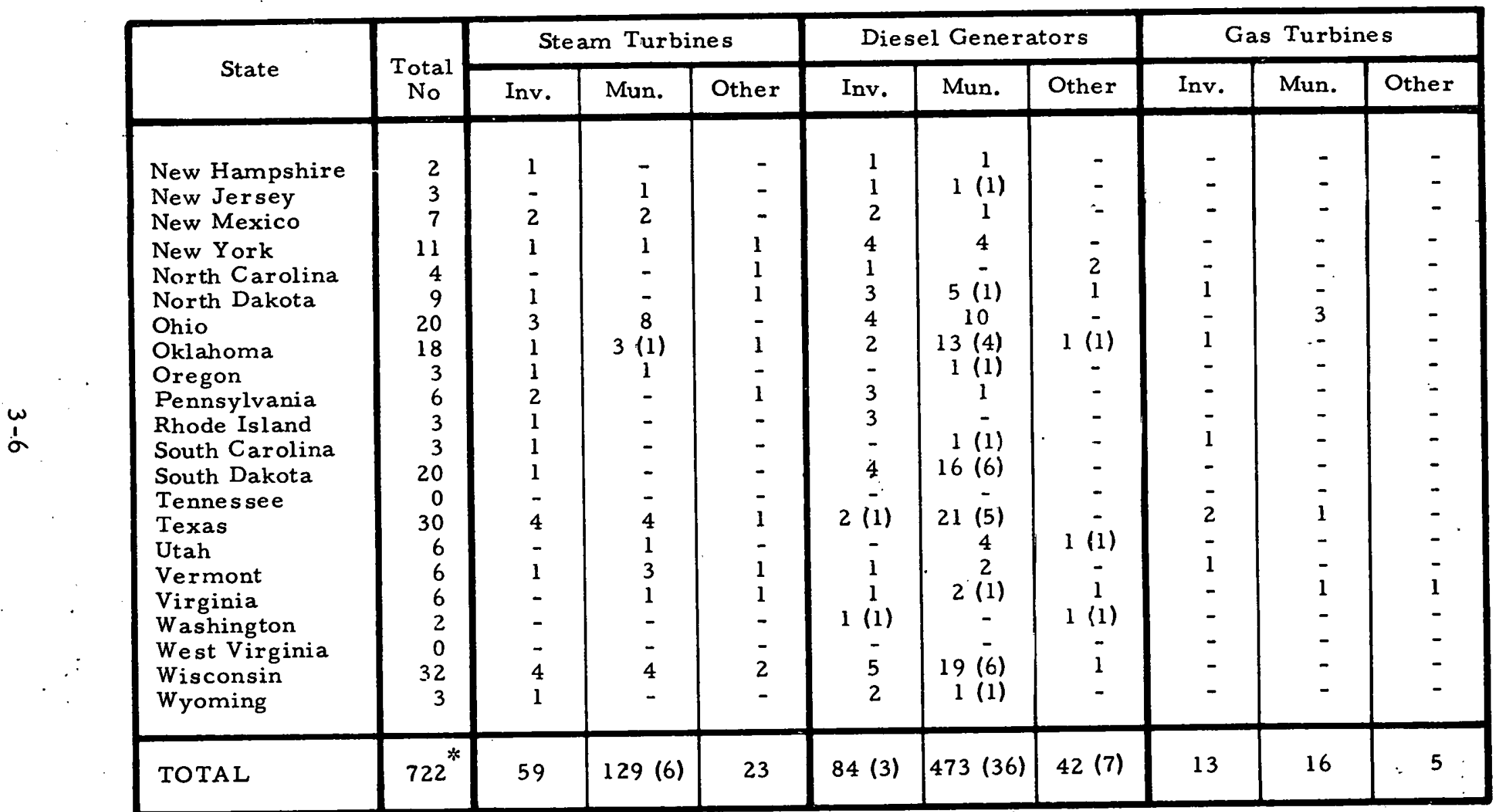

* Actual number of utility systems is 716 since four companies have units in more than one state. 
Table 3-2. Summary of Small ( $\leq 10 \mathrm{MW}$ e) Power Units in the United States

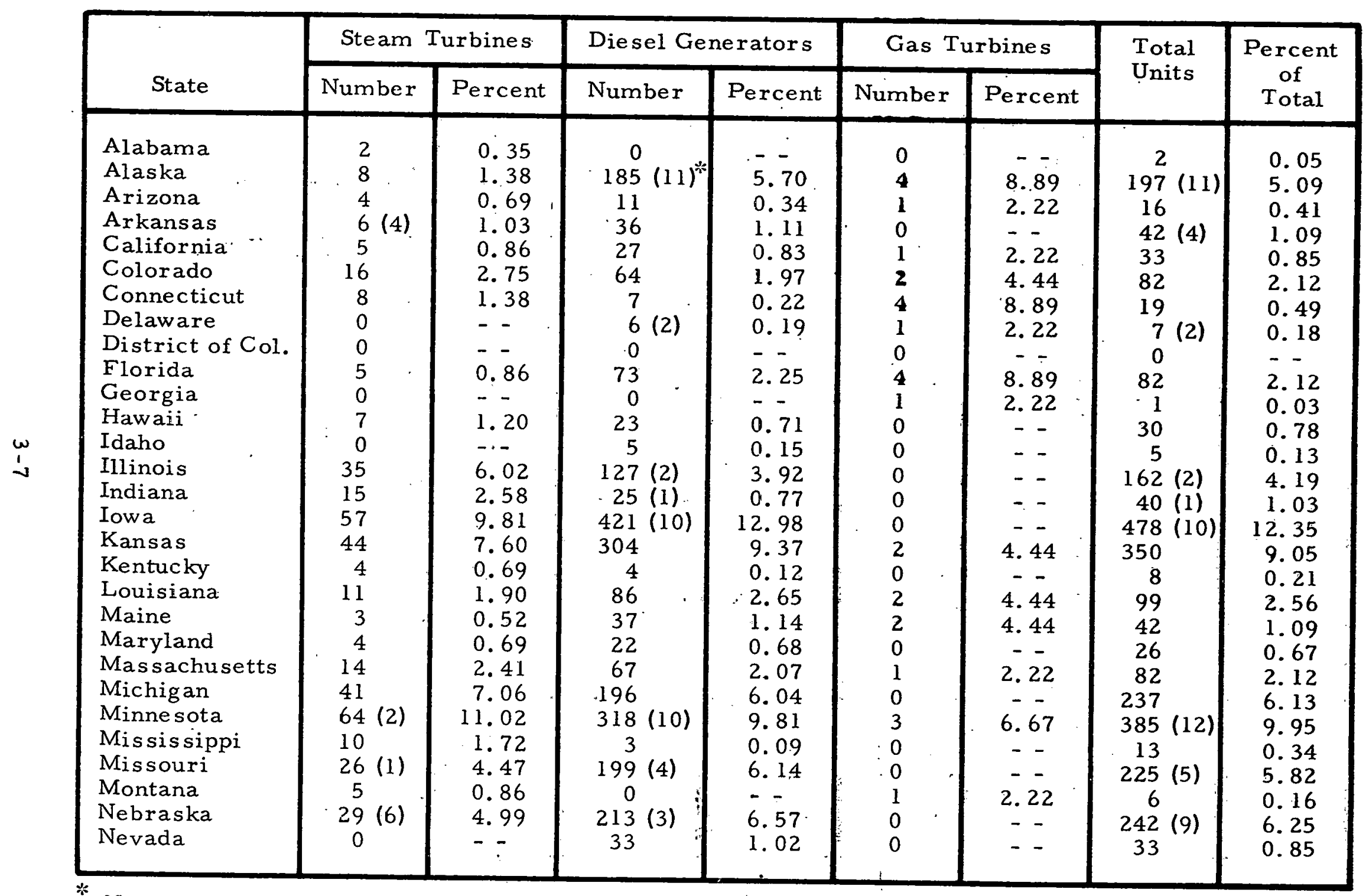

\footnotetext{
Number of Standby Units.
} 
Table 3-2. Summary of Small $\left(\leq 10 \mathrm{MW}_{\mathrm{e}}\right.$ ) Power Units in the United States (Cont'd)

\begin{tabular}{|c|c|c|c|c|c|c|c|c|}
\hline \multirow{2}{*}{ State } & \multicolumn{2}{|c|}{ Steam Turbines } & \multicolumn{2}{|c|}{ Diesel Generators } & \multicolumn{2}{|c|}{ Gas Turbines } & \multirow{2}{*}{$\begin{array}{l}\text { Total } \\
\text { Units }\end{array}$} & \multirow{2}{*}{$\begin{array}{c}\text { Percent } \\
\text { of } \\
\text { Total }\end{array}$} \\
\hline & Number & Percent & Number & Percent & Number & Percent & & \\
\hline $\begin{array}{l}\text { New Hampshire } \\
\text { New Jersey } \\
\text { New Mexico } \\
\text { New York } \\
\text { North Carolina } \\
\text { North Dakota } \\
\text { Ohio } \\
\text { Oklahoma } \\
\text { Oregon } \\
\text { Pennsylvania } \\
\text { Rhode Island } \\
\text { South Carolina } \\
\text { South Dakota } \\
\text { Tennessee } \\
\text { Texas } \\
\text { Utah } \\
\text { Vermont } \\
\text { Virginia } \\
\text { Washington } \\
\text { West Virginia } \\
\text { Wisconsin } \\
\text { Wyoming }\end{array}$ & $\begin{array}{r}4 \\
4 \\
12 \\
12 \\
2 \\
6 \\
35 \\
10(2) \\
4 \\
4 \\
3 \\
1 \\
3 \\
0 \\
16 \\
4 \\
4 \\
2 \\
0 \\
0 \\
29 \\
3\end{array}$ & $\begin{array}{l}0.69 \\
0.69 \\
2.07 \\
2.07 \\
0.34 \\
1.03 \\
6.02 \\
1.72 \\
0.69 \\
0.69 \\
0.52 \\
0.17 \\
0.52 \\
-- \\
2.75 \\
0.69 \\
0.69 \\
0.35 \\
-- \\
-.- \\
4.99 \\
0.52\end{array}$ & $\begin{array}{l}10 \\
6(2) \\
23 \\
49 \\
12 \\
50(3) \\
50 \\
37(17) \\
1(1) \\
34 \\
17 \\
1(1) \\
69(14) \\
0 \\
142(28) \\
24(2) \\
18 \\
23(2) \\
18(18) \\
0 \\
96(11) \\
11(4)\end{array}$ & $\begin{array}{l}0.31 \\
0.18 \\
0.71 \\
1.51 \\
0.37 \\
1.54 \\
1.85 \\
2.68 \\
0.03 \\
1.05 \\
0.52 \\
0.03 \\
2.13 \\
-.- \\
4.38 \\
0.74 \\
0.56 \\
0.71 \\
0.56 \\
-.- \\
2.96 \\
0.34\end{array}$ & $\begin{array}{l}0 \\
0 \\
0 \\
0 \\
0 \\
2 \\
3 \\
2 \\
0 \\
0 \\
0 \\
1 \\
0 \\
0 \\
3 \\
0 \\
2 \\
3 \\
0 \\
0 \\
0 \\
0\end{array}$ & $\begin{array}{l}-- \\
-- \\
-- \\
-- \\
-- \\
4.44 \\
6.67 \\
4.44 \\
-- \\
-- \\
-- \\
2.22 \\
-- \\
-- \\
6.67 \\
-- \\
4.44 \\
6.67 \\
-- \\
-- \\
-- \\
--\end{array}$ & $\begin{array}{c}14 \\
10(2) \\
35 \\
61 \\
14 \\
58(3) \\
98 \\
99(19) \\
5(1) \\
38 \\
20 \\
3(1) \\
72(14) \\
0 \\
161(28) \\
28(2) \\
24 \\
28(2) \\
18(18) \\
0 \\
125(11) \\
14(4)\end{array}$ & $\begin{array}{l}0.36 \\
0.26 \\
0.91 \\
1.58 \\
0.36 \\
1.50 \\
2.53 \\
2.56 \\
0.13 \\
0.98 \\
0.52 \\
0.08 \\
1.86 \\
-- \\
4.16 \\
0.72 \\
0.62 \\
0.72 \\
0.47 \\
-.- \\
3.23 \\
0.36\end{array}$ \\
\hline TOTAL & $581(15)$ & 100.00 & 3243 & 100.00 & 45 & 100.00 & 3869 & 100.00 \\
\hline
\end{tabular}


action by municipal utilities and/or cooperatives with investor-owned utility systems. However, action has been initiated in the latter two states to change the law. Consideration is being given to challenging the constitutionality of the Arizona law with respect to the feature which precludes municipal utility systems from jointly funding and building new power plants with investor-owned systems. If such teaming becomes permissible in these three states, and possibly in other states, there 13 a very high probability that, by 1985 or 1990, many municipal utility systems may own a share of large coal-fired steam plants. Such action would reduce the market for small solar thermal power systems and should be monitored closely by DOE to see whether a trend develops in this direction.

\subsubsection{Location of Small Power Units}

Table 3-2 indicated the percentile by state for each type of generating unit and for the total number of small generating units. Almost one-third $(31.35 \%)$ of all small generating units are located in three midwestern states, Iowa (12.35\%), Minnesota (9.95\%), and Kansas (9.05\%). Three additional midwestern states, Nebraska (6.25\%), Michigan $(5.13 \%)$, and Missouri (5.82\%), account-for a little over one-fourth of the remaining small power units in the United States. These six midwestern states account for just under half $(49.55 \%)$ of all the small electrical generating units in the United States. The annualized average daily direct insolations (Reference 6) for these six states are given in Table 3-3, along with the projected 1985 natural gas and No. 2 fuel oil prices in these states (Reference 7 ) and the percentile of small power units located in each state. The average statewide solar insolation and 1985 fossil fuel cost data have been included in the table to provide a preliminary indication of the relative attractiveness of solar thermal power systems in the various states of potential interest for this study. Actual. insolation values for the five specific cities used in the 
Table 3-3. States With Highest Percentages of Small Power Units

\begin{tabular}{|c|c|c|c|c|c|}
\hline \multirow[t]{2}{*}{ State } & \multirow{2}{*}{$\begin{array}{l}\text { Percent of } \\
\text { Small Units }\end{array}$} & \multirow{2}{*}{\multicolumn{2}{|c|}{$\begin{array}{c}\text { Annualized Average } \\
\text { Daily Direct Insolation }(\mathrm{a} \\
\text { (kWh/m } / \text { day) }\end{array}$}} & \multicolumn{2}{|c|}{$\begin{array}{c}\text { Average 1985: Fuel Prices } \\
\left(1977 \$ / 10^{6} \mathrm{Btu}\right)\end{array}$} \\
\hline & & & & Natural Gas & No. 2 Fuel Oil \\
\hline $\begin{array}{l}\text { Iowa } \\
\text { Minne sota } \\
\text { Kansas } \\
\text { Nebraska } \\
\text { Michigan } \\
\text { Missouri } \\
\text { Alaska } \\
\text { Illinois } \\
\text { Texas } \\
\text { Wisconsin } \\
\text { Louisiana } \\
\text { Oklahoma } \\
\text { Ohio } \\
\text { Colorado } \\
\text { Florida } \\
\text { Massachusetts } \\
\text { South Dakota } \\
\text { New York } \\
\text { North Dakota } \\
\text { Maine } \\
\text { Arkansas } \\
\text { Indiana } \\
\text { Pennsylvania } \\
\text { New Mexico } \\
\text { California } \\
\text { Nevada } \\
\text { Utah } \\
\text { Arizona }\end{array}$ & $\begin{array}{l}12.35 \\
9.95 \\
9.05 \\
6.25 \\
6.13 \\
5.82 \\
5.09 \\
4.19 \\
4.16 \\
3.23 \\
2.56 \\
2.56 \\
2.53 \\
2.12 \\
2.12 \\
2.12 \\
1.86 \\
1.58 \\
1.50 \\
1.09 \\
1.09 \\
1.03 \\
0.98 \\
0.91 \\
0.85 \\
0.85 \\
0.72 \\
0.41\end{array}$ & $\begin{array}{l}4.7 \\
4.5 \\
5.6 \\
5.5 \\
3.7 \\
5.0 \\
5.1(\mathrm{~b}) \\
4.1 \\
5.0-6.0 \\
4.0 \\
4.0 \\
5.5 \\
4.0 \\
6.0 \\
4.1 \\
3.8 \\
5.0 \\
3.8 \\
5.0 \\
3.7 \\
4.8 \\
4.3 \\
3.7 \\
6.5 \\
6.0-7.5 \\
6.5 \\
5.8 \\
7.5\end{array}$ & $\because$ & $\begin{array}{l}2.44 \\
2.45 \\
2.65 \\
2.81 \\
3.07 \\
2.54 \\
0.91 \\
3.00 \\
2.59 \\
2.72 \\
2.40 \\
2.53 \\
3.16 \\
2.12 \\
3.30 \\
4.26 \\
2.34 \\
3.50 \\
3.27 \\
4.35 \\
2.83 \\
2.92 \\
3.30 \\
2.02 \\
3.19 \\
2.15 \\
2.34 \\
1.96\end{array}$ & $\begin{array}{l}3.50 \\
3.73 \\
3.59 \\
3.47 \\
3.54 \\
3.76 \\
3.49 \\
3.60 \\
3.73 \\
3.69 \\
3.52 \\
3.47 \\
3.71 \\
3.71 \\
3.60 \\
3.68 \\
3.78 \\
3.59 \\
3.60 \\
3.68 \\
3.73 \\
3.64 \\
3.69 \\
3.65 \\
3.80 \\
3.76 \\
3.69 \\
3.64\end{array}$ \\
\hline
\end{tabular}

(a) Prevailing Insolation values within state, depending upon location. These values are lower than the values for the five specific locations used in the breakeven cost analysis.

(b) Insolation value for Alaskan interior area of interest. 
breakeven cost analysis reported in Section 4 tend to run somewhat higher than the statewide averages. Analyses of the cost-effectiveness of small solar thermai power systems in five southwestern states are discussed in Section 4.

The five southwestern "sun belt" states of Arizona, Calffornia," Nevada, New Mexico, and Texas contain only 7.18 percent of the small power units in the United States. The addition of Colorado, Oklahoma, and Utah would contribute another 5.40 percent of the small generating units in the U.S. Together, these eight southwestern states have just under one-ejghth. of all. the small. generating units in the United States. Data for thése eight states are also included in. Table 3-3.

Each of the remaining 14 states of the 28 listed in Table 3-3 has at least one percent of the small electrical generating units in the U.S. Together, these 28 states have a little more than 93 percent of the total U.S. small, fossil-fueled power generating units. The map in Figure 3-1 shows where these 28 states are located in the Unj.ted States.

\subsubsection{Ownership of Small Uti]ity Systems}

Table I in Volume II of this Technical Summary Report lists each of the 716 utility systems In the United States with electrical

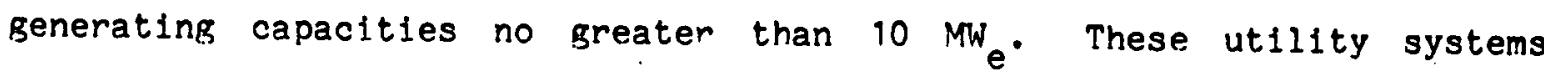
are identified as investor-owned, municipally-owned, or other (primarily cooperatives). Table 3-4 summarizes the type of ownersh1p of these 716 utility systems by state. Standby. utility systems or the standby diesel generator portions of these systems are indicated in parentheses in the table. Investor-owned utility systems, municipally-owned utility systems, and electrical cooperatives, respectively, comprise 15.22, 76.12 , and 8.65 percent of the total United States ut1lity system. If 


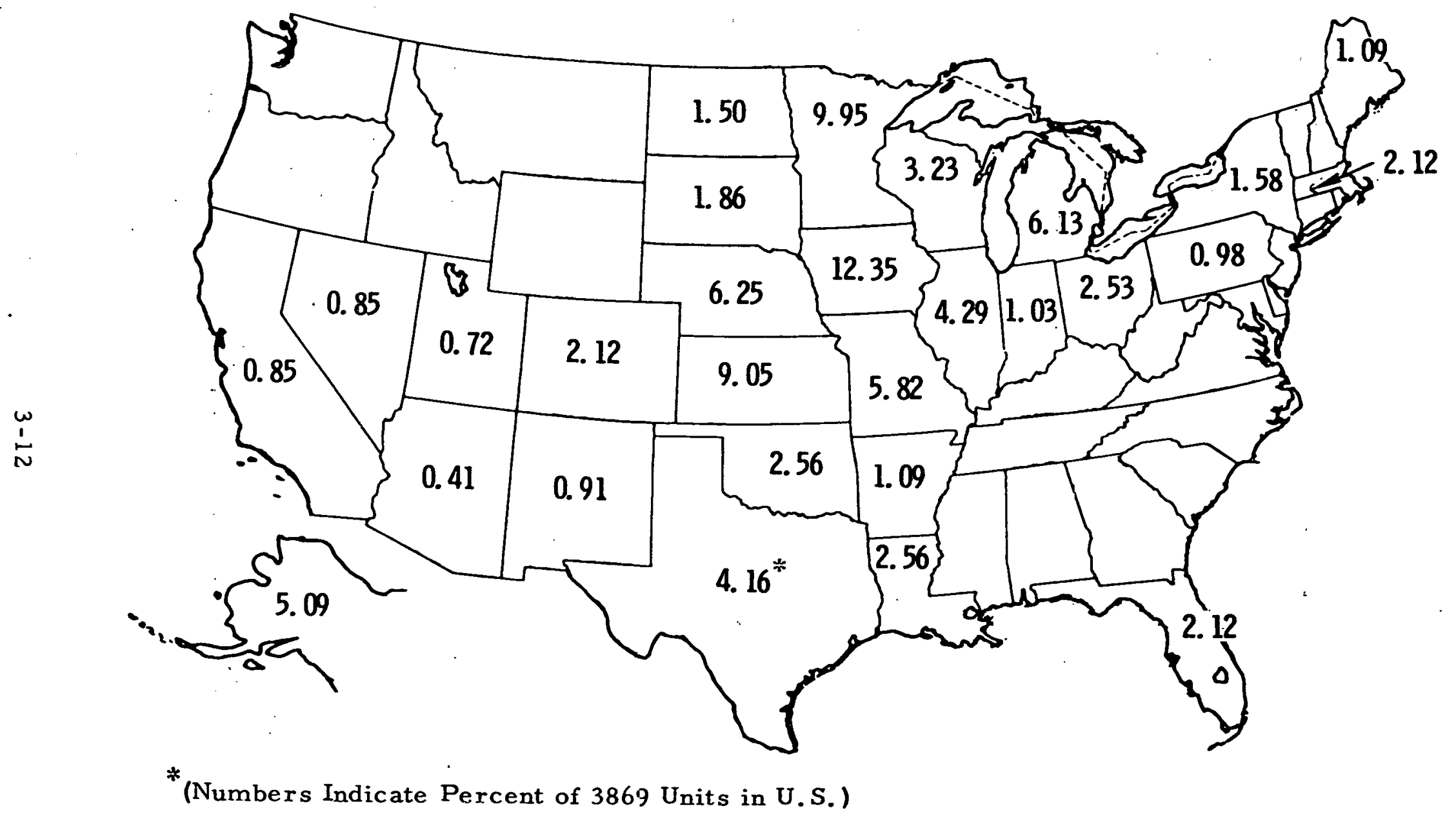

Figure 3-1. Distribution of Small Power Units 
Table 3-4. Ownership of Small Utility Systems in the United States

\begin{tabular}{|c|c|c|c|c|}
\hline \multirow{2}{*}{ State } & \multicolumn{3}{|c|}{ Number of Utility Systems } & \multirow{2}{*}{ Total } \\
\hline & Investor-Owned & Municipally-Owned & Others & \\
\hline $\begin{array}{l}\text { Alabama } \\
\text { Alaska } \\
\text { Arizona } \\
\text { Arkansas } \\
\text { California } \\
\text { Colorado } \\
\text { Connecticut } \\
\text { Delaware } \\
\text { District of Col. } \\
\text { Florida } \\
\text { Georgia } \\
\text { Hawaii } \\
\text { Idaho } \\
\text { Illinois } \\
\text { Indiana } \\
\text { Iowa } \\
\text { Kansas } \\
\text { Kentucky } \\
\text { Louisiana } \\
\text { Maine } \\
\text { Maryland } \\
\text { Massachusetts } \\
\text { Michigan } \\
\text { Minnesota } \\
\text { Mississippi } \\
\text { Missouri } \\
\text { Montana } \\
\text { Nebraska } \\
\text { Nevada } \\
\text { New Hampshire } \\
\text { New Jersey }\end{array}$ & $\begin{array}{l}0 \\
2 \\
1 \\
1 \\
3 \\
2 \\
3 \\
1 \\
0 \\
1 \\
0 \\
1 \\
0 \\
4 \\
4(1) \\
5 \\
4 \\
0 \\
1 \\
3 \\
2 \\
5 \\
3 \\
4(b) \\
0 \\
6 \\
2 \\
0 \\
3 \\
1 \\
1\end{array}$ & $\begin{array}{c}0 \\
10 \\
1 \\
9(1) \\
1 \\
13 \\
2 \\
2(1) \\
0 \\
10 \\
0 \\
0 \\
2 \\
23(1) \\
6 \\
80(3) \\
56 \\
3 \\
15 \\
1 \\
3 \\
8 \\
20 \\
62(1) \\
4 \\
37(2) \\
0 \\
54(3) \\
0 \\
1 \\
2(1)\end{array}$ & $\begin{array}{l}1 \\
\left.12(1)^{6}\right) \\
2 \\
0 \\
1 \\
1 \\
0 \\
0 \\
0 \\
1 \\
1 \\
0 \\
0 \\
2 \\
0 \\
3 \\
3 \\
0 \\
0 \\
2 \\
0 \\
0 \\
5 \\
6(2) \\
0 \\
2 \\
0 \\
3(1) \\
0 \\
0 \\
0 \\
\end{array}$ & $\begin{array}{r}1 \\
24 \\
4 \\
10 \\
5 \\
16 \\
5 \\
3 \\
0 \\
12 \\
1 \\
1 \\
2 \\
29 \\
10 \\
88 \\
63 \\
3 \\
16 \\
6 \\
5 \\
13 \\
28 \\
72(\mathrm{~b}) \\
4 \\
45 \\
2 \\
57 \\
3 \\
2 \\
3\end{array}$ \\
\hline
\end{tabular}


Table 3-4. Ownership of Small Utility Systems in the United States (Cont'd)

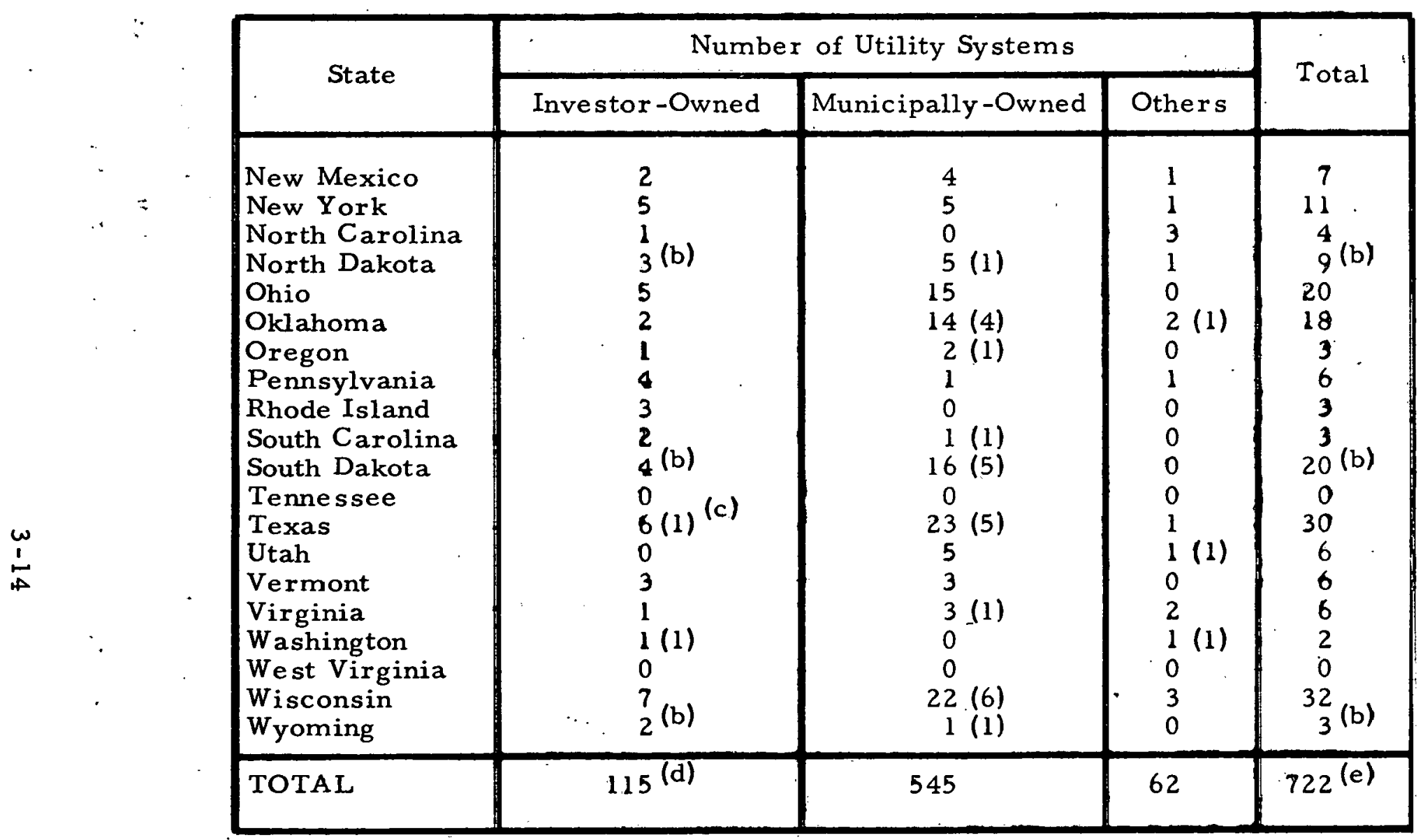

(a) Number in parenthesis indicates number of utility systems on standby.

(b) Two of the citility companies wera counted three times, since they have plants in Minnesota, North Dakota, and. South Dakota; one of the utility companies has plants in both North Dakota and South Dakota and courted twice; and one ut lity has plants in South Dakota and Wyoming and was counted twice.

(c) Only diesel units are on standby.

(d) Actual number of investor-ownec utility systems with small units is 109 .

(e) Actual number of small utility systems in U.S. is $71 \epsilon$. 
one examines the distribution of the standby ut1lity systems, by type of ownership, the two percent of the investor-owned utility systems: on standby have put only their diesel generators on standby and are continuing to operate their remaining steam and gas turbine units; however, seven and elght percent, respectively, of the municipal utility systems and electrical cooperatives are either completely on standby or, 1f they are large systems, have placed all of their smal.1 ( $\leqslant 10 \mathrm{MW}_{\mathrm{e}}$ ) generating units on standby.

Discussions "with several muntcipal utility systems and electrical cooperatives indicate that the increasing cost of operating small generating units, combined with interruptions of natural gas supplies to utilities, has created a situation where it $1 . s$ cheaper for many of these systems to purchase all of their power, rather than a portion of their power, from a major ut1lity system. As natural gas prices continue to Increase, and the avaliablitity of the gas decreases, more of these small utility systems can be expected to go on standby and operate simp!y as a distribution system. In addition, as pointed out in Section 3.1.1, many of the municipal. litility. systems and a few of the cooperatives are Investigating the possib1lity of jolnt ventures with each other and/or investor-owned ut1litles for large, coa!-fired plants. Should this possiblitity become an eventuality as a result of changes in vartous state laws; the number of separate generating entities could decrease not 1ceably by the mid-1980s.

\section{$3.1 .4 \quad$ S1ze D1stribution of Small Generating Units}

The generating capacities of the varlous small power units in the Unfted States range from less than $100 \mathrm{~kW}_{\mathrm{e}}$ to $10 \mathrm{MW}_{\mathrm{e}}$. In general, the smallest units in a given ut1lity system are the oldest, especlally in the case of steam turbines and diesel generators. Based on discussions with several municipal utility systems, the older, smaller 
diesel units are being replaced by units with higher generating capacities as these utility systems expand their total capacities to meet the growing demands on the systems. Thus, in many cases, the total number of generating units in a utility system may not increase even though the capacity may increase significant?y.

Tables $3-5$ and $3-6$, respectively, show the size distribution by state of steam and gas turbines, and diesel generators, using data from Table I of Volume II of this Technical Summary Report. A generating unit with a generating capacity equal to the boundary value betireen two adjacent generating groups is always listed in the lower capacity group, 1.e., a $8 \mathrm{MW}$ steam. turbine will he listed in the 7-8 $\mathrm{MW}$ sroup. The 0-10 MW range of generating capacity has been divided uniformly into one megawatt groups for the steam and gas turbines. The capacity range below one megawatt was divided into five groups for the diesel generators to reflect the large number of generating units in that range.

\subsubsection{Interviews With Small Power System Users}

A number of small powcr syetem operators and users (munficipal utilities and cooperatives) in the southwestern United States were contacted by telephone to determine their decision-making processes relative to meeting increased power demands in the future and to find out how knowledgeable they were about solar thermal power. A detajled questionnaire has been prepared in draft form to solicit more extensive information from these and other small power system users or potential users, but the questionnaire has not been tested on any of the users at this time.

The telephone interviews were conducted with either the City Manager or the Manager of a municipal utility system, and with either the Manager or Chief Engineer of an electric cooperative. The user was told 
Table 3-5. Number of Small Steam/Gas 'Turjines as a Function of Generating Capacity

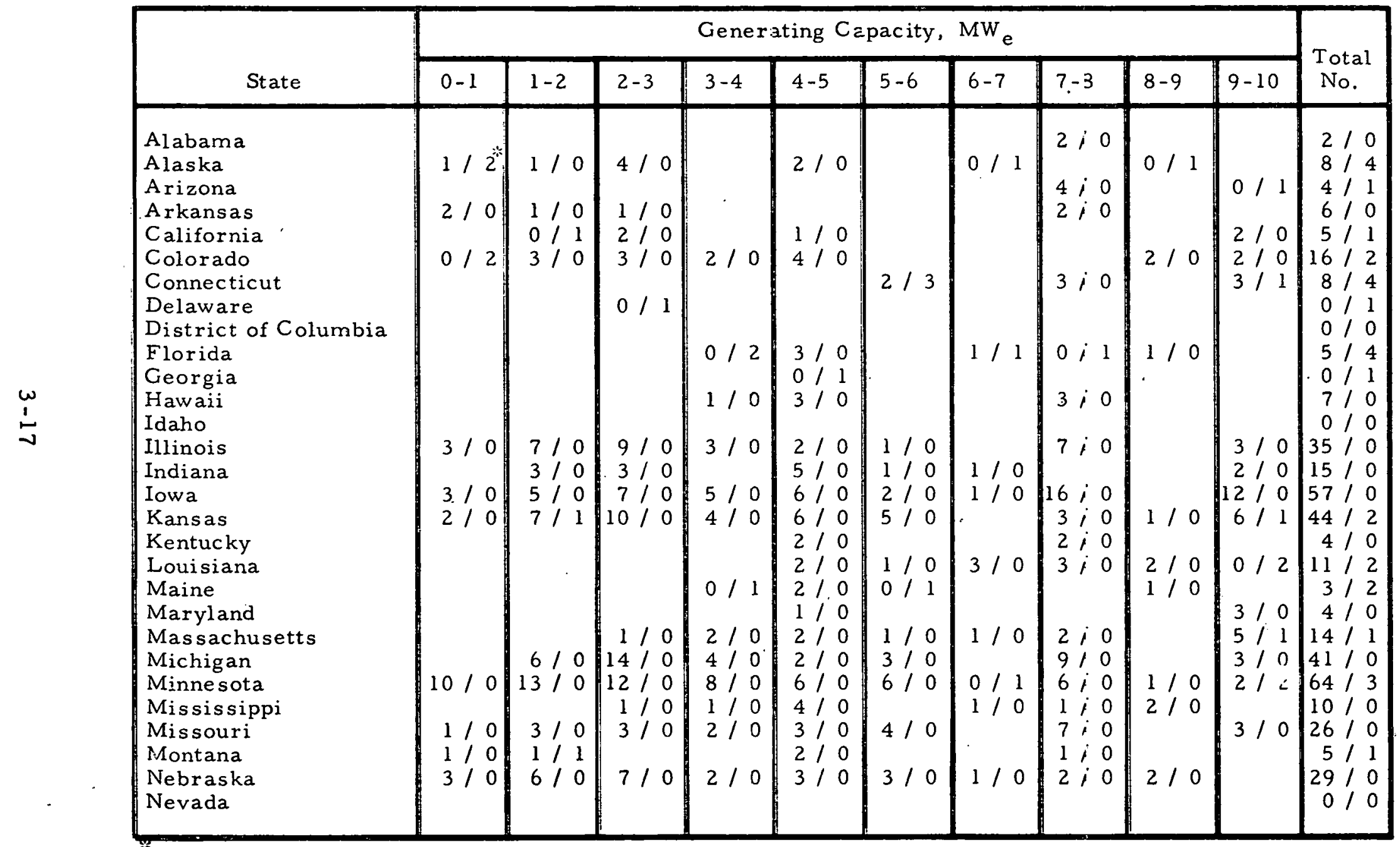

Number of Steam Turbines/Number of Gas Turbines. 
Table 3-5. Number of Small Steam!Gas Turbines as a Function of Generating Capacity (Cont'd)

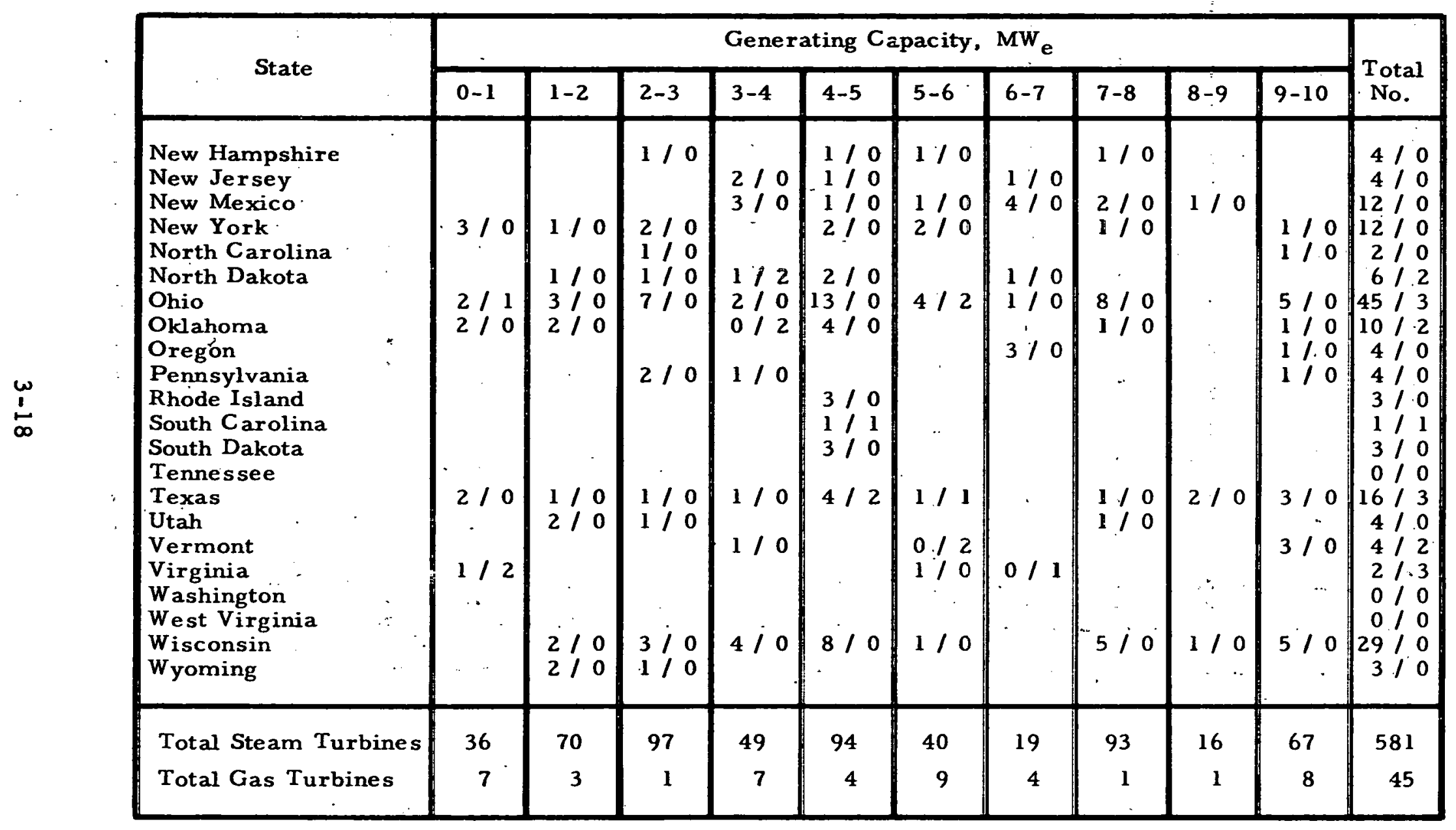


Table 3-6. Number of Small Diesel Generators as a Function of Generating Capacity

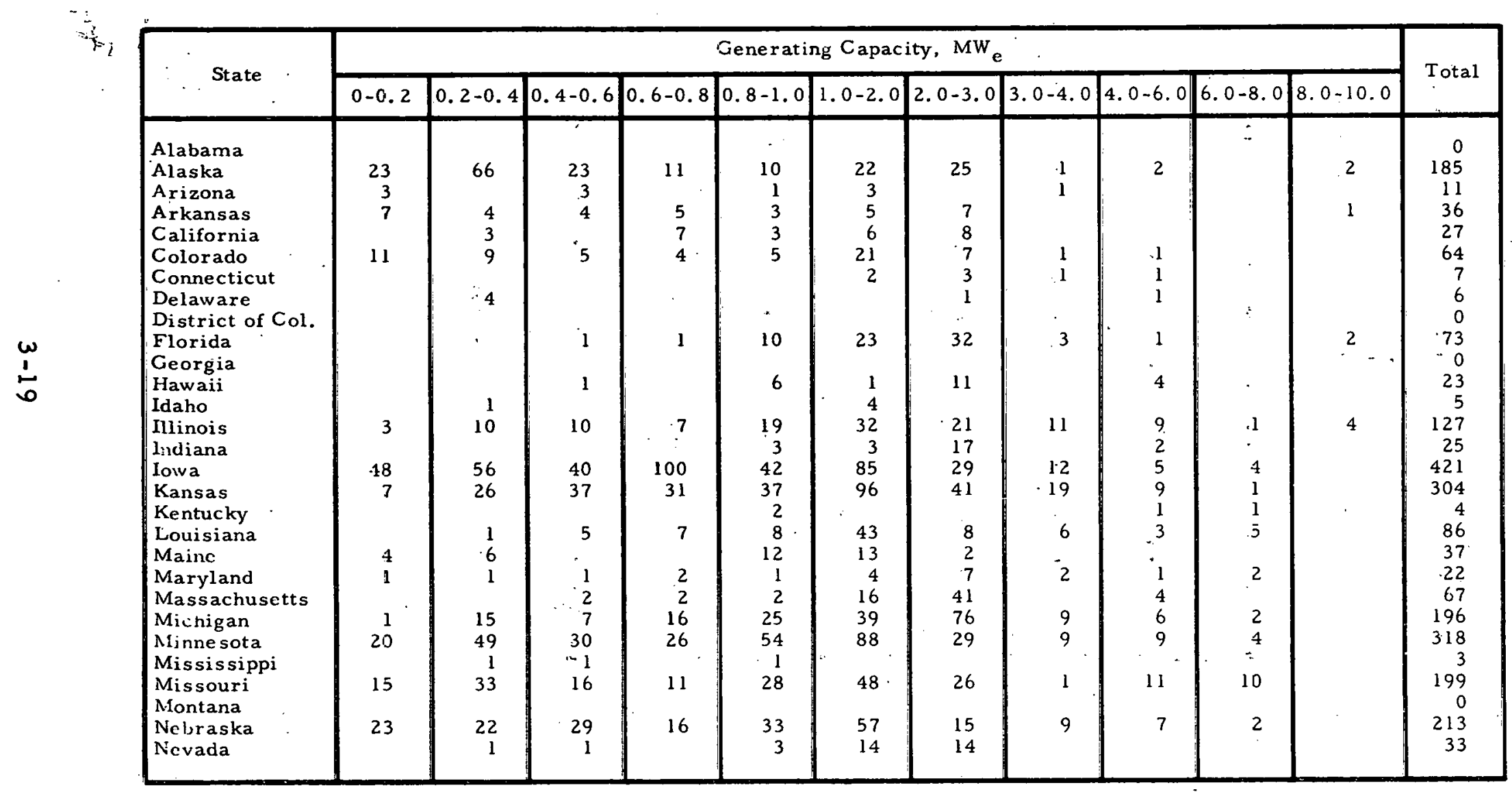


Table 3-6. Number of Small Diesel Generators as a Function of Generating Capacity (Cont'd)

\begin{tabular}{|c|c|c|c|c|c|c|c|c|c|c|c|c|}
\hline \multirow{2}{*}{ State } & \multicolumn{11}{|c|}{ Generating $C_{\text {apacity, }} \mathrm{MW}_{\mathrm{e}}$} & \multirow{2}{*}{ Total } \\
\hline & $0-0.2$ & $0.2-0.4$ & $0.4-0.6$ & $0.6-0.8$ & $0.8-1.0$ & $1.0-2.0$ & $2.0-3.0$ & $3.0-4.0$ & $4.0-6.0$ & $6.0-8.0$ & $8.0-10.0$ & \\
\hline $\begin{array}{l}\text { New Hampshire } \\
\text { New Jersey } \\
\text { New Mexico } \\
\text { New York } \\
\text { North Carolina } \\
\text { North Dakota } \\
\text { Ohio } \\
\text { Oklahoma } \\
\text { Cregon } \\
\text { Pennsylvania } \\
\text { Rhode Island } \\
\text { South Carolina } \\
\text { South Dakota } \\
\text { Tennessee } \\
\text { Texas } \\
\text { Utah } \\
\text { Vermont } \\
\text { Virginia } \\
\text { Washington } \\
\text { West Virginia } \\
\text { Wisconsin } \\
\text { Wyoming }\end{array}$ & $\begin{array}{r}1 \\
6 \\
2 \\
1 \\
2 \\
\\
3 \\
13 \\
8 \\
1 \\
1 \\
1 \\
10 \\
16 \\
1\end{array}$ & $\begin{array}{r}2 \\
1 \\
1 \\
3 \\
11 \\
1 \\
4 \\
\\
3 \\
18 \\
12 \\
2 \\
3 \\
3 \\
16 \\
3\end{array}$ & $\begin{array}{r}2 \\
1 \\
1 \\
2 \\
4 \\
4 \\
11 \\
\\
1 \\
13 \\
5 \\
1 \\
2 \\
7 \\
2 \\
9\end{array}$ & $\begin{array}{r}2 \\
8 \\
7 \\
6 \\
7 \\
\\
8 \\
10 \\
1 \\
1 \\
10\end{array}$ & $\begin{array}{r}3 \\
2 \\
4 \\
2 \\
12 \\
4 \\
8 \\
1 \\
2 \\
7 \\
7 \\
17 \\
3 \\
4 \\
2 \\
2 \\
16 \\
1\end{array}$ & $\begin{array}{r}1 \\
4 \\
6 \\
13 \\
1 \\
15 \\
14 \\
34 \\
12 \\
4 \\
1 \\
9 \\
50 \\
12 \\
11 \\
3 \\
\\
\\
20 \\
5\end{array}$ & $\begin{array}{r}7 \\
8 \\
\\
26 \\
16 \\
22 \\
4 \\
1 \\
27 \\
4 \\
6 \\
1 \\
6 \\
1\end{array}$ & $\begin{array}{l}2 \\
4 \\
4 \\
2 \\
4\end{array}$ & $\begin{array}{l}1 \\
4 \\
1 \\
3\end{array}$ & & 1 & $\begin{array}{r}10 \\
6 \\
23 \\
49 \\
12 \\
50 \\
60 \\
87 \\
1 \\
34 \\
17 \\
1 \\
69 \\
0 \\
142 \\
24 \\
18 \\
23 \\
18 \\
0 \\
96 \\
11\end{array}$ \\
\hline TOTAL & 232 & 391 & 281 & 306 & 398 & 840 & 549 & 108 & 94 & 32 & 12 & 3243 \\
\hline Percent of Total & 7.15 & 12.06 & 8.66 & 9.44 & 12.27 & 25.90 & 16.93 & 3.33 & 2.90 & 0.99 & 0.37 & 100.00 \\
\hline
\end{tabular}


that The Aerospace Corporation was performing a study for the Department of Energy to determine the market potential for solar thermal small power systems and the purpose of the interview was to develop a better understanding of some of the problems facing small utility systems in the future and how these utilities might attempt to resolve these problems. The interview also attempted to determine how familiar the users were with solar thermal power systems and under what circumstances the user would consider solar power systems in his future plans.

In general, a majority of the users were familiar with the study that the Public Service Company of New Mexico is doing for the Division of Solar Technology (DST). Some of the municipal utility systems were also aware of the Crosbyton, Texas, and Hobbs, New Mexico, studies for DST. These systems expressed some interest in finding out how to obtain DOE funding for similar studies by their cities. These small municipal utility systems do not do long range planning, probably because they are too small to have planning staffs; they simply try to cope with the problem of meeting increasing power demands over the next five years.

Except for those systems which are completely isolated from the power grid in the United States, future increases in demand are most likely to be met simply by purchasing additional power from the present external supplier. The question of the relative, cost of purchased power versus locally generated power is not being addressed by most of these small utilities since the increased cost of purchased (or locally generated) power is simply passed on to the ultimate user. This position appeared surprising since municipal utility systems generally provide a significant amount of revenue to the owning cities and it would appear that the more revenue the utility system generated, the more the municipality would receive. The explanation apparently is that the municipal utility system imposes a distribution charge on its customers 
for the purchased power and is able to generate revenue without having to incur the capitalization costs of expanding the existing power system. The municipality also would probably derive revenue from the external supplier directly through franchise costs. Since the municipality does not incur any cost in this mode of operation, the high initial capital costs of the solar power system may be a major problem with respect to introducing solar thermal power systems into municipal utility systems.

One other point must be made with respect to the attitude of both municipal utility systems and electric cooperatives in terms of their ability to meet increasing power demands by their users. Both types of utility systems are actively examining or taking positive action to acquire part interest in large, coal-fired power plants to be constructed in the next five to ten years. This action stems directly from the improved technical performance of large systems and because of their economy of scale. If these utility systems become owners of large power plants in the next ten years, the market for small solar thermal power systems could be drastically curtalled.

Some legal problems currently do exist in Arizona and New Mexico in the Southwest, as well as in Pennsylvania and possibly other states, which prevent joint action by municipal utility systems with investor-owned or other muntcipal systems. However, action is being taken in the New Mexico and Pennsylvania leglslatures to remedy the law during the next year and, in Arizona, the constitutionality of the state law may be challenged. In some of the southwestern states, electric cooperatives do not appear to be precluded from joint operations with either municipal or investor-owned utility systems, possibly because they are governed in their actions by the Rural Electrification Act rather than by state law. 
The remainder of this section summarizes the telephone conversations with 14 utility systems in the Southwest. The ut1lities include both generating, and non-generating systems, and municipal ut1lities and electric cooperatives. The 14 systems, in alphabetical order, are:

Arizona Electric Power Cooperative, Inc.

Brazos Electric Power Cooperative, Inc.

Bridgeport Light and Power Dept.

Clayton Municipal Electric System

Farmington Electric Ut1lity

Hearne Munioipal Electric System

Lea County Eleotric Cooperative, Inc.

Mesa C1ty Ut1lities

Plains Eleotrio Generation and Transmission Cooperative, Inc.

Raton Public.Service Company

Safford Muniolpal Ut1lities

Swlsher Eleotric Cooperat1ve, Ino.

Tucumcar1 Light and Power Dept.

Tul1a Muniolpal L1ght and Water Dept.

3.1.5.1 Arizona Eleotric Power Cooperative, Inc., Benson, Ar1zona

The Arizona Electric Power. Cooperative supplies power to most of the eleotric cooperatives in Arizona. It has a generating capacity of $168 \mathrm{MW}$, using both steam and gas turbines. In addition, it is currently. purchasing about half of its power from the U.S. Bureau of Reolamation, the Arizona Public Service Company, and the Arizona Pawer Pooling Assoolation. Its requirements are covered by this arrangement through the early 1980s. It is involved in the Cactus Power Pool, which includes companies in Arizona, New Mexico, and the El Paso area of Texas. The Pool's total capacity is 6000-7000 $\mathrm{MW}_{e}$. The Pool is 
investigating the feasibility of new coal-fired steam plants. These plants currently require a 5-6 year lead time, but the new plants should be avaflable by the mid-1980s when the power would be needed. Very little interest was shown in solar power systems by the Cooperative because it feels that these systems are too far downstream to fit within its current planning horizon of 5-10 years. The Arizona Electric Power Cooperative is completely aware of the study by the Public Service Company of New Mexico and receives the PSNM reports to DOE, posisibiy because PSNM is a member of the Cactus Power Pool.

\subsubsection{Brazos Electric Power Cooperative, Ino., Waco, Texas}

Brazos Electric. Power Cooperative supplies power to REA Cooperatives in 64 counties in Texas. It has a total generating capacity of $455 \mathrm{MW}$, which is produced by eight steam turbines using natural gas as. the fuel. The cooperative does not anticipate any problem in continuing to get adequate supplies of gas. The Cooperative purchases approximately one-third of its ... power from several investor-owned utilities and the Lower Colorado River Authority. It owns 70 percent of the San Miguel Electric Cooperative, Inc., which was organized in 1977 as a joint venture with the Medina and South Texas Electric Cooperatives to construct and operate a $400 \mathrm{MW}$ lignite-fueled, mine mouth steam unit about 50 miles south of San Antonio. A second $400 \mathrm{MW}$ unit is planned after the first unit goes on line in 1980. The current growth rate in demand in the Brazos Electric service area is approximately 10 percent per year. An interesting sidelight on future power systems came from the Manager of Power Production for the Cooperative who stated that, as far as he was concerned, the only way to go with solar power was with the Satellite Solar Power System. 
3.1.5.3 Bridgeport Light and Power Dept., Bridgeport, Texas

The Bridgeport municipal utility system distributes power
purchased from Texas. Power and Light Company of Dallas. The city feels that j.t can produce its power more cheaply in the long run than it can purchase it. The city has discussed the sell-back of surplus power, produced by a solar thermal power system, to Texas Power and Light, but is being given very unfavorable sell-back rates by the utility. Texas Power and Light, at the present time, is only willing to pay one-third to one-fourth as much for surplus power as it charges Bridgeport for power. Bridgeport belifeves that it may be able to jmprove the ratio to one-half if it actually installs solar power units. It appears that Bridgeport assumes that it will be able to have the Federal Government and the Governor's Energy Advisory Council of the State of Texas cover most, if not all, of the capital cost for a solar thermal power system. Bridgeport would then repay a portion of the costs from revenues derived from the solar power system. Bridgeport is currently under contract to DOE to study the feasibility of a solar thermal power system. The final report should be avallable in late June or July 1978.

\subsubsection{Clayton Municipal Electric System, Clayton, New Mexico}

The Clayton municipal power system is isolated from any external source of power by a distance of approximately 50 miles. The city estimates that it could run a transmission line from either the Tucumcari. municipal system or the Springer terminal of the Plains Electric Cooperative for about $\$ 1,000,000$, which appears to be quite low for the distance involved. The city currently is operating six dual-fuel. diesel generators with a total capacity of about $4 \mathrm{MW}_{\mathrm{e}} \cdot$ Growth in demand is relatively low, a steady 2-3 percent per year, so that no new generating capacity will have to be added for the next several years. The service area of the clayton system is primarily rural, consisting of 
ranches and agrlculture. As a result, the users of the system have relatively fixed incomes. Increases in the cost of fuel for the clayton system have caused some hardship for many of the users due to the resulting increases in the cost of power. The costs of natural gas and oll are now about equal on an energy basis and the city is relatively Indifferent to which fuel it uses, although it preferred bas in the past because of the lower price. The DOE recently installed a $200 \mathrm{~kW}$ windmill in Clayton, which is tied into the power system and appears to be working satisfactorily. Even if solar power is technically feastble in the Clayton area, the high initial capital cost of a solar power system would present major financing problems to Clayton. The problem is highlighted here because f.t appears that some type of financial support will be required if smajl, rural, municipal utility systems are to be able to afford the initial cost of a solar thermal power system. In an urban area, the municlpality may be able to finance the solar power system much more easily if it chooses to install the system.

\subsubsection{Farmington Electric Utility, Farmington, New Mexico}

Farmingtion currently produces ahout one-half of its power with four steam turbines, the smallest two of which are used only when necessary due to their low efficiency. The two large turbines have a capacity of $23.5 \mathrm{MW}_{\mathrm{e}}$. Additional power is purchased from the U.S. Bureau of Reclamation. Although the present power plant is only about 20 years old, it has had poor maintenance in the past and is not performing wel.1. The city plans to phase out the p.lant, which uses natural gas as the fuel, and is planning, on satisfying its future needs with power acquired from, the Public Service Company of New Mexico. Farmington would prefer to go into a joint venture. with PSNM on a new, coal-fired plant to be bullt south of Farmington, but New Mexico state law presently precludes such a joint venture between an investor-owned and municipal. utility system. However, legislation ts to be introduced in the 1979 New Mexico legislature to permit such joint endeavors. If the legislation 
does not pass, Farmington plans to purchase the power from PSNM. The city is currently experiencing a second boom as a result of the oil and gas activities in the area and growth in demand is increasing at the rate of 12 percent per year.

\subsubsection{Hearne Municipal Electric System, Hearne, Texas}

The Hearne municipa? system produces about 90 percent of i.ts power with five diesel generators $\left(7.78 \mathrm{MW}_{\mathrm{e}}\right)$ and purchases the remainder of its power from the Brazos Electric Power Cooperative. The city believes that it can buy economy peak power from the Bryan (Texas) Municipal Electric. System more cheaply than from Brazos due to the proximity of Bryan and its reduced transmission costs. However, the city will continue to purchase power from Brazos to keep its future options open. The city does not plan to add any generating capacity to its system and will purchase additional power, as needed, in the future.

\subsubsection{Lea County Electric Cooperative, Inc., Lovington, New Mexico}

This cooperative generates approximately 90 percent $(69.5$ $M_{e}$ ) of its own power using steam turbines and diesel generators. It purchases the balance of its power from the Southwestern Public Service Company of Amarillo, Texas. The Lea County Cooperative is currently funding a systems study by an Abfilene, Texas, A\&E firm to determine the best alternative to accommodate future growth in the Cooperative's power demand. Alternatives include purchase of additional power from SPS, purchase of a share of new coal-burning power plants to be put on line by SPS, or adding additionaj generating capacity. The study is scheduled to be completed about the end of June 1978. The Lea County Electric Cooperative is also preparing to drill. gas wells in the Permian Basin of southeastern New Mexico to assure itself of an adequate supply of natural gas which will not be subject to price increases, as would be the case 
with an outside supplier of natural gas. Drilling should begin before the end of 1978 .

\subsubsection{Mesa City Utilities, Mesa, Arizona}

The Mesa municipal. utility system is a distribution system for power currently purchased from the U.S. Bureau of Reclamation. The city's peak power requirements in 1975 were approximately $50 \mathrm{MW}$ in the summer and $36 \mathrm{MW}$ in the winter. Mesa will be unable to obtain additional power from the USBR since no more generating capacity is available. In the future, the additional power will be supplied by the Arizona Electric Power Cooperative, which will deliver the power over the USBR transmission lines. The city is considering a joint venture with the city of Tempe, Arizona, for a $20 \mathrm{MW}$ solid waste product power plant but is prevented from doing so by the current Arizona state law against "credit" arrangements by municipalities. The law is believed to be unconstitutional but has not been tested in the courts. Mesa is giving consideration to challenging the law. Mesa is willing to consider solar power if it looks attractive in the future compared to other alternatives. The concept of small power units $\left(\leqslant 10 \mathrm{MW}_{\mathrm{e}}\right)$ appeals to the city for reliability and reserve reasons. The city can issue bonds but has never done so in the past for utility purposes.

3.1.5.9 Plains Electric Generation and Transmission Cooperative, Inc., Albuquerque, New Mexico

Plains Flectric serves 11 REA cooperatives in the western two-thinds of New Mexico. It produces about one-fourth of its power with three gas-fired steam turbines, each rated at $16.5 \mathrm{MW}_{\mathrm{e}}$. The Cooperative is currently switching over to oil since it cannot depend on natural gas supplies after 1980. The remainder of the power for the Plains Electric Cooperative is purchased from the Public Service Company 
of New Mexico. The rate of growth in power demand in the Plains Electric system is 16-18 percent per year because of the large increases in population and mining activities in its service area. It spent over a year trying to work out arrangements for a joint venture for a new power plant with an investor-owned utility system but the project fell through for unspecified reasons. It currently has an environmental study under way for a new, coal-fired plant. Construction of this plant, the exact siting of which must still be determined, is to start in 1980-1982 and the plant is to be on line in the mid-1980s with a capacity of

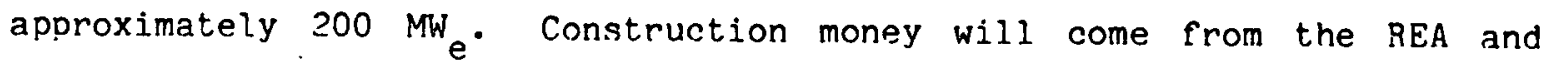
will cost about 8 percent.

\subsubsection{Raton Public Service Company, Raton, New Mexico}

Raton is generating more than 90 percent of its own power with two small coal-fired steam turbines with a peak capacity of $10.2 \mathrm{MW}_{\mathrm{e}}$. The larger of the two steam turbine units, when it was installed in 1962 , cost $\$ 1,400,000$ and is capable of generating $6.6 \mathrm{MW}$. Raton purchases its remaining power from the Springer Electric Cooperative, Inc., which purchases all of its power from the Plains Electric Cooperative. Raton is looking at a joint venture with five colorado cities on a large coal-fired plant to be constructed near Colorado Springs.

\subsubsection{Safford Municipal Utilities, Safford, Arizona}

Safford generates about one-fourth of its power with 10 diesel generators rated at $7.08 \mathrm{MW}_{e}$. These diesels were installed in the late 1930 s and $1940 \mathrm{~s}$ and will have to be replaced soon. Safford purchases the remainder of its power from the Graham County Electric Cooperative which, in turn, buys its power from the Arizona Electric Power Cooperative. The AEPC has informed Safford that the AEPC is willing to provide whatever power safford needs in the future, but that Safford will have to pay the 
prevailing price for power. Safford is aware of the Public Service Company of New Mexico study on solar thermal power systems for the DOE and has considered solar power as a future alternative for the city. It has concluded that it cannot afford solar power. The city is considering the addition of propane to its natural gas supply to keep its generating costs down. It is also interested in trying to exploit geothermal deposits near the city as a means of reducing its power costs.

\subsubsection{Swisher Electric Cooperative, Inc., Tulia, Texas}

The Swisher Cooperative purchases all of its power from the Southwestern Public Service Company (SPS). In 1975, the peak summer and winter demands were 34 and $17 \mathrm{MW}$, respectively. Although Swisher's power demand is increasing at a rate of 15 percent per year, primarily due to an expansion of irrigation in its service area, Southwestern Public Service sees no problem in meeting Swisher's future demands. The Swisher Electric Cooperative is one of 15 members of Group 5 of the Texas Electric Cooperatives, Inc., the Texas state cooperative organization. Group 5 has discussed the development of its own generating capacity but. has not taken any action up to this time. However, rising fuel costs are producing a more serious constderation of self-generation of power in Group 5. Each of the seven Groups in the 84-member Texas co-op organization has a planning committee and Swisher has a member on the Group 5 Planning Committee, although he is not a professional planner.

\subsubsection{Tucumcari Light and Power Dept., Tucumcari, New Mexico}

The Tucumcari municipal power system is a stand-alone system with a peak generating capacity of $16.2 \mathrm{MW}$ provided by eight diesel Benerators. The city has a 10-year gas contract, but purchases its diesel fuel on a year-by-year basis. The utility is a mafor source of revenue to the city. The utility system is now near its limit on an 
acceptable capacity margin. Public Service Company of New Mexico and Southwestern Public Service Company have had discussions on constructing an intertie between the two utility systems, which could run in the vicinity of Tucumcari. Southwestern Public Service has indicated to Tucumcarl that it would cost $\$ 6-8$ million to hook Tucumcarl into the grld. Tucumcari feels that 1 t can produce power more cheaply than it can purchase the power from Southwestern Public service. The Farmers Electrlc Cooperative, Ino: of New Mckleo, whlch has a service area around Tucumcari, buys its power from SPS. Tucumcari would prefer to purchase Its power from Farmers Electric Cooperative if the Cooperative could obtain the power needed for Tucumcarl at a reasonabje rate from Southwestern Public Service.

\subsubsection{Tul1a Municipal Light and Water Dept., Tul1a, Texas}

The Tulia municipal power system is supposedly the last remaining 1solated ut1lity system in west Texas and is located approximately six miles from the nearest polnt on the grid. Southwestern Public Service is asking approximately $\$ 700,000$ to tie Tulia into the sps system. The Tulla system consists of 10 dual-fuel diesels with a peak capacity of approximately $15 \mathrm{MW} \mathrm{e}^{-}$Tulia is currently ready to purchase a second hand, three-megawatt diesel generator from Canada for about $\$ 500,000$ to Increase 1 ts capacity. Tulla purchases both the natural gas and diesel fuel for 1 ts generators on a year-by-year basis, but prefers natural gas since it is still cheaper than o1l. Since Tulla uses less than three million cublc feet of natural gas per day, it is exempt from restrictions on the use of natural gas for ut1lity systems in Texas. Tulla belleves that natural gas will continue to be reasonably priced in west Texas because Southwestern Public Service, the largest natural gas user in the area, is in the process of converting 1 ts power plants to coal and nuclear fuels. Once SPS stops being a consumer of natural gas, Tulia feels that Ploneer Gas Company, the local suppliter, w11l either. 
hold its price constant or even lower it slightly to pick up new customers to offset the loss of Southwestern Public Service as its major customer. Tulia is interested in both solar power and wind for its power system and will probably contact the DOE for assistance in determining the feasibility of such systems.

\subsection{CHARACTERISTICS OF SMALL SOLAR THERMAL POWER SYSTEMS}

The cost data used to analyze the small solar thermal power systems are contained in this section of the report. The data for both central receivers and point-focusing distributed collectors are of two types, performance and economic. The data on central receivers are taken either from McDonnell Douglas data (Reference 2) or from Aerospace Corporation data (Reference 1) derived primarily from data in Reference 2, but modified as described in Section 3.2.1. The data on point-focusing distributed collectors were taken from a Jet Própulsion Laboratory (JPL) report (Reference 3).

The cost data on centra]. receivers in References 1 and 3 do not agree. However, no attempt has been made at this time to resolve the differences since the breakeven cost analyses presented in Section 4 are intended solely for the purpose of determining which variables are the drivers that should be studied in more detall in the follow-on study. In addition, the breakeven cost analyses are intended to provide some initial guifance on acceptable upper cost limits for solar thermal power systems, regardless of their. type, if the solar thermal systems are to be competitive with conventional. power systems.

The cost data will be evaluated in the follow-on study when more refined breakeven cost analyses are carried out. This evaluation is also required in order to place the two types of solar thermal power systems, i.e., central receivers and distributed collectors, on a 
compatible basis since they represent different states-of-the-art and cannot both be competing for the 1985 commercial market. It is also possible, although the analysis to substantiate the supposition still must be performed, that the distributed collectors may be more cost-effective at the lower end of the power range and central receivers may be better as one approaches the upper limit of the power range. If there is a role for central receivers in the small power system market, then advanced central receivers, which have not been considered in Reference 3, must be compared with the advanced distributed collectors advocated by JPL. The required evaluations of competing solar thermal. power systems will be carried out in the follow-on study only to the extent of determining whether there is a role for one or both types of solar thermal small power system in the small power system market. Based on direction from DST, this evaluation will not be a systems analysis to optimize the two types of competing solar thermal power systems for the purpose of selecting the preferred concept for this application.

\subsubsection{Central Receiver Power Systems}

Figure 3-2 depicts a $10 \mathrm{MW}$ central receiver electrical power plant based on the design for the DOE/Southern California Edison (SCE) Company plant at Barstow, California. Design parameters of this McDonnel1 Douglas-designed plant are given in Table 3-7. Basically, the central receiver concept consists of a field of two-axis tracking heliostats, which focus the solar insolation on a receiver mounted in a tower. The receiver heats steam, the working fluid, which is converted into energy by passing it through a Rankine cycle power plant. Additional steam generated in the receiver is used to energize a thermal storage system, which can provide energy to the power system for a varying period of time (e.g., three hours for the Barstow system), based upon the size of the storage system. 


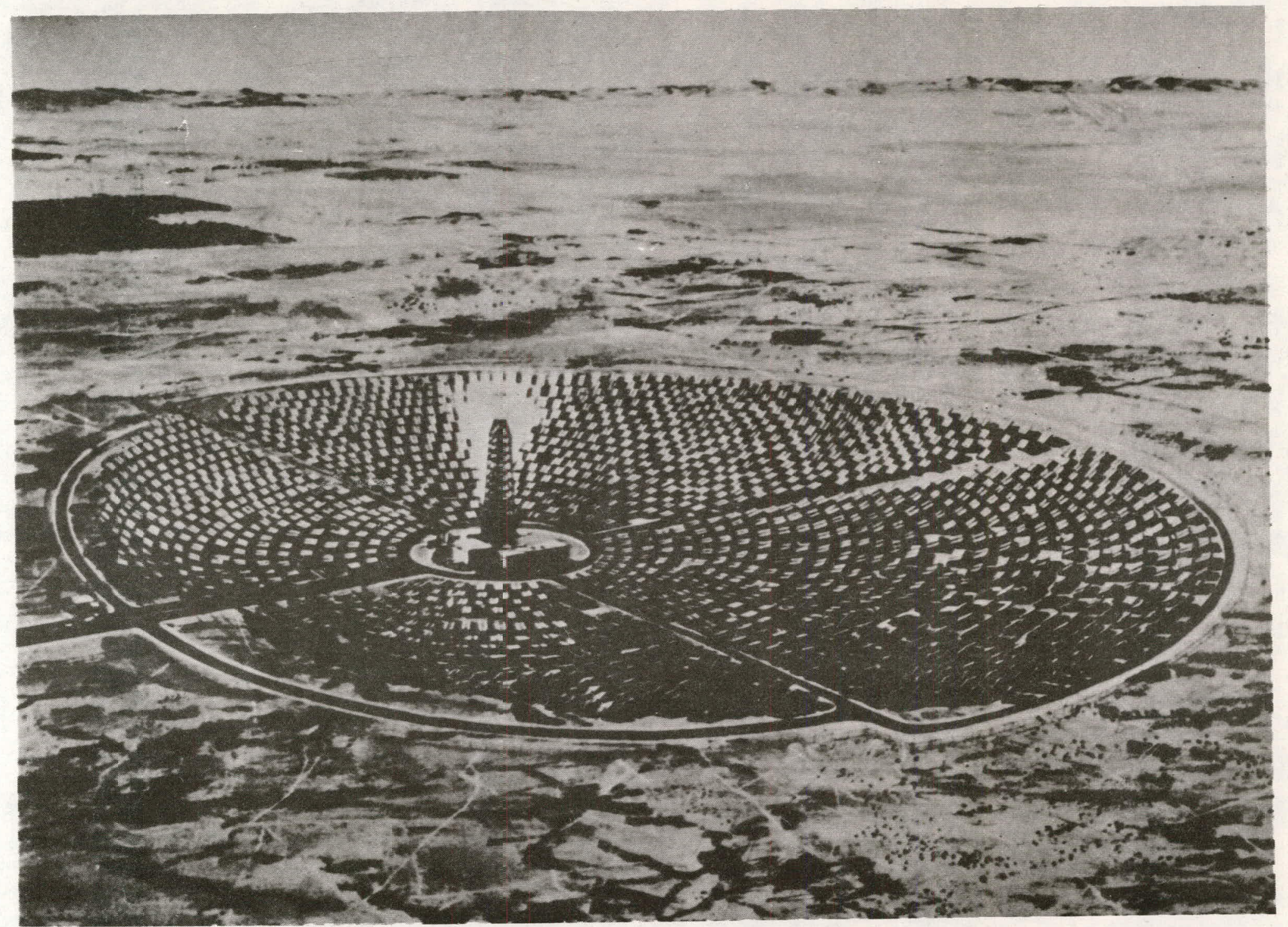

Figure 3-2. McDonnell Douglas Design for $10 \mathrm{MW}$ Central Receiver Solar Power Plant 
Table 3-7. Design Characteristics of $10 \mathrm{MW}_{\mathrm{e}}$ Power Plant System Requirements

Design Point Power Level

Receiver (2 PM, worst cosine day)

Thermal. Storage

Design Insolation

Solar Multiple

Thermal Storage Capacity

Maximum Thermal Storage Chomg Rato

System Startup Times

Hot

Cold

System Availability

Electrical Output

Minimize within practical limits

Collector Field Physical Characteristics

$10 \mathrm{MW}$ e net
$7 \mathrm{MW}$ e net
$950 \mathrm{~W} / \mathrm{m}^{2}$

1. 1

3 Hours

$30 \mathrm{MWW}_{\mathrm{t}}$

20 Minute $s^{*}$

6 Hours

90 Percent...

Compatible Poith 
Table 3-8 presents the cost-estimating relationships (CERs) which had been used earlier in this Study (Reference 1, Table 3-14) and the current CERs. Cost elements 10 through 13 have been revised downward to reflect the fact that recent analyses indicate that these four cost elements are less sensitive to the size of solar thermal power plants than had been believed earlier. The modifled CERs treat distributables, indirect costs, contingency, and non-recurring tooling. Figure 3-3 - displays the cost of central receiver solar power plants without thermal storage as a function of power plant generating capacity and production quantity.

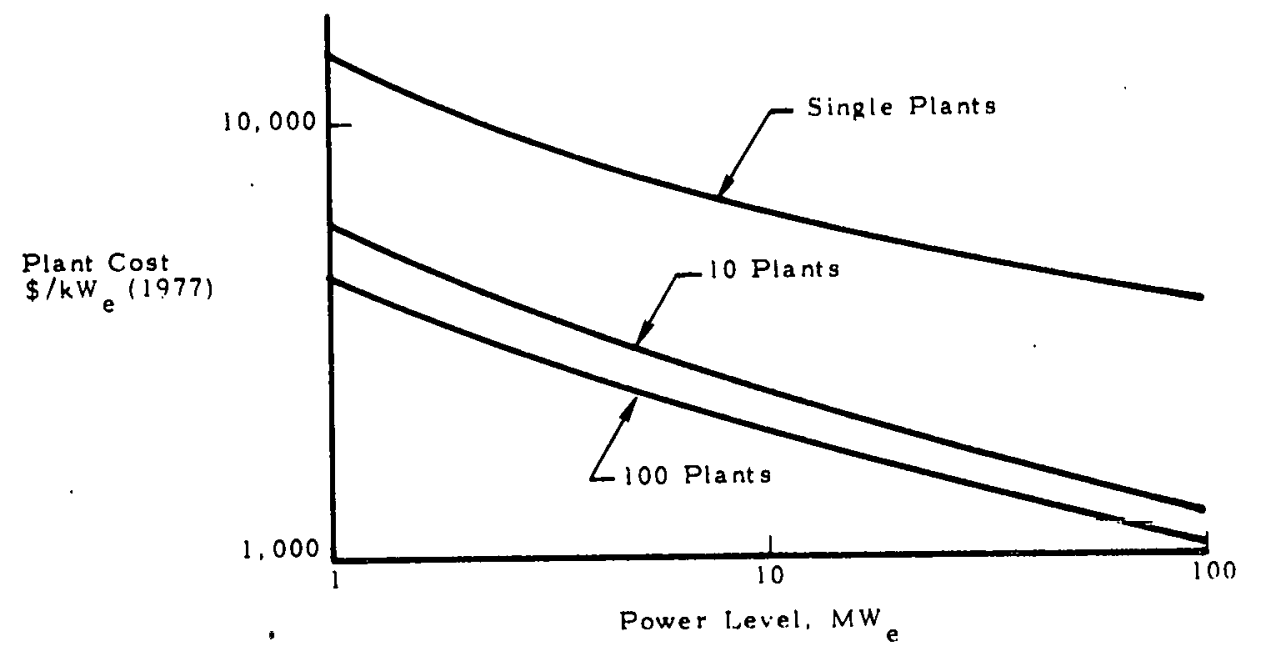

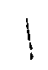

Figure 3-3. Central Recelver Costs as a Function of Power 'Level and Production Quantity

\subsubsection{Distributed Collector Power Systems}

Two preferred options for point focusing, distributed collector solar thermal power systems, on the basis of data presented in Reference 3, are the parabolic dish collector with either steam or 
Table 3-8. Cost Model (FSF 058) for Central Receiver Power Piants (Average Plant Cost)

\begin{tabular}{|c|c|c|}
\hline ID & Cost Element & Estimating Relationship, $\$ / \mathrm{kW}$ \\
\hline (1) & Land Costs & $2.47 \times 10^{-4} \times A_{L}\left(M W_{e}\right)^{-1}$ \\
\hline (2) & Land Preparation & $2.76 \times 10^{2}\left(\mathrm{MW}_{\mathrm{e}}\right)^{-0.628}$ \\
\hline (3) & Buildings & $4.26 \times 10^{2}\left(\mathrm{MW}_{\mathrm{e}}\right)^{-0.536}\left(\mathrm{Q}_{\mathrm{p}}\right)^{-0.074}$ \\
\hline (4) & $\begin{array}{l}\text { Electric Plant } \\
\text { Equipment }\end{array}$ & $2.91 \times 10^{3}\left(M W_{e}\right)^{-0.773}\left(Q_{p}\right)^{-0.074}$ \\
\hline (5) & Turbine-Generator & $1.12 \times 10^{3} \frac{\mathrm{MW}_{\mathrm{e}}^{-0.345}}{\mathrm{~N}_{3}}\left(\mathrm{Q}_{\mathrm{p}} \times \mathrm{N}_{3}\right)^{-0.074}$ \\
\hline$(6 a)$ & $\begin{array}{l}\text { Limited Heliostats } \\
\text { Production }\end{array}$ & $666 \times 10^{-3}\left(\mathrm{MW}_{\mathrm{e}}\right)^{-1}\left(\mathrm{Q}_{\mathrm{s}}\right)^{-0.119} \times \mathrm{Ac}_{\mathrm{c}}$ \\
\hline$(6 b)$ & $\begin{array}{l}\text { Large Heliostats } \\
\text { Production }\end{array}$ & $403 \times 10^{-3}\left(M W_{e}\right)^{-1}\left(Q_{s}\right)^{-0.119} \times A_{c}$ \\
\hline (7) & Receiver Subsystem & $2.43 \times 10^{3} \frac{\mathrm{MW}_{\mathrm{e}}^{-0.46}}{\mathrm{~N}_{1}}\left(\mathrm{Q}_{\mathrm{p}} \times \mathrm{N}_{1}\right)^{-0.074}$ \\
\hline (8) & Thermal Storage & $1.92 \times 10^{4} \frac{\mathrm{kW}_{\mathrm{s}} \mathrm{h}^{-0.462}}{\mathrm{~N}_{2}} \mathrm{~h}_{\mathrm{s}} \times \frac{\mathrm{kW} \mathrm{s}}{\mathrm{MW}_{\mathrm{e}}}\left(\mathrm{Q}_{\mathrm{p}} \times \mathrm{N}_{2}\right)^{-0.074}$ \\
\hline
\end{tabular}


Table 3-8. Cost Model (FSP 058) for Central Receiver Power Plants (Average Plant Cost Cont'd)

\begin{tabular}{|c|c|c|c|}
\hline (9) & Direct Plant Costs & $\sum($ & \\
\hline 、 & r & Reference 1 & Current Value \\
\hline$(10)$ & Distributables & (9) $\times 0.12\left(\mathrm{MW}_{\mathrm{e}}\right)^{-0.237}$ & (9) $\times 0.042$ \\
\hline$(11)$ & Indirect & (9) $\times 0.549(\mathrm{MW})^{-0.485}$ & (9) $\times 0.09$ \\
\hline$(12)$ & Contingency & (9) $\times 0.304(\mathrm{MW})^{-0.494}$ & (9) $\times 0.06$ \\
\hline$(13)$ & $\begin{array}{l}\text { Non-Recurring } \\
\text { Tooling }\end{array}$ & $0.672\left(\mathrm{MW}_{\mathrm{s}}\right)^{-0.743}$ & $0.011 \Sigma$ \\
\hline & Total Inve stment. Cost & & \\
\hline
\end{tabular}

Where

\begin{tabular}{|c|c|c|c|}
\hline Application & Description & Symbol & Units \\
\hline Total System & $\begin{array}{l}\text { Total System Capacity } \\
\text { Total Quantity of Heliostats }\end{array}$ & $\begin{array}{l}\mathrm{MW}_{\mathrm{S}} \\
\mathrm{Q}_{\mathrm{s}}\end{array}$ & Megawatto \\
\hline $\begin{array}{l}\text { Individual } \\
\text { Plant }\end{array}$ & $\begin{array}{l}\text { Plant Size } \\
\text { Plant Land Area } \\
\text { Number of Plants } \\
\text { Plant Collector Area } \\
\text { No. of Receivers per Plant } \\
\text { No. of Thermal Storage } \\
\text { Subsysteme per Plant } \\
\text { No. of Turbine Generatoro } \\
\text { per Plant } \\
\text { Busbar Energy from Storage } \\
\text { Storage Time }\end{array}$ & $\begin{array}{l}M W_{e} \\
A_{L} \\
Q_{p} \\
A_{c} \\
N_{1} \\
N_{2} \\
N_{3} \\
k W_{B} \\
h_{B}\end{array}$ & \begin{tabular}{|l} 
Megawatts \\
Square \\
Meters \\
-- \\
Square \\
Meters \\
$\therefore$ \\
-- \\
-- \\
Kilowatts \\
Hours
\end{tabular} \\
\hline
\end{tabular}


electric transport of the energy. These two systems are shown conceptually in Figures 3-4 and 3-5, respectively. Each of the units would be capable of generating 15-25 $\mathrm{kW}_{e}$, depending upon the operating characteristics of the system; and could be aggregated to form a system capable of generating power in the megawatt range.

In the steam transport syștem, the steam is generated by means of receivers mounted at the focal point of each parabolic dish; the steam is then transported through insulated pipes to a central steam Rankine plant. The collector fleld is arranged to generate saturated steam in the outer region of the fleld and superheated stean oloser to the central power plant. The steam transport system is not as attractive a system as the electric transport system because of 1 ts lower performance, but $1 t$ nould be avallable in the near term moreas the electric transpopt syatein: would become avaliable at a later date.

The eleotrio transport concept uses a small heat engine-generator mounted at the focal point of the parabolic dish to generate eleotriolty directly. A Brayton cycle gas turbine is preferred for the near term and a high temperature stirling or advanced Brayton oycle engine for the far term. The potential advantage of the eleotrio transport system is the ease of connecting the electrical leads from the Individual generating units to bulld up a fleld capable of producing the exact level of power desired for a speciflo application. However, a sophisticated control system will be required to synchronize the Individual generating units. It would also appear that it would be relatively simple to add more units at a later date to expand the system capacity. Additional steam transport units would be much more difficult to integrate into an existing system except as a modular group of colleotors or unless the turbogenerator were over-designed to accept additional steam at a later date. 


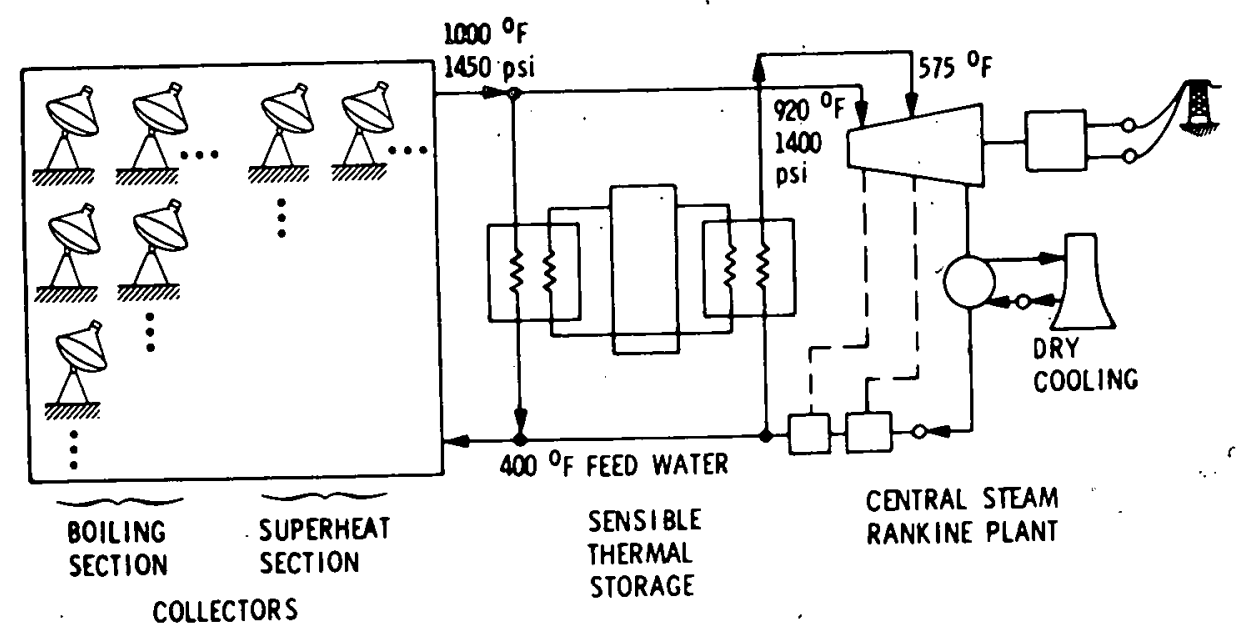

Figure 3-4. Parabolic Dish Collector With Steam Transport System

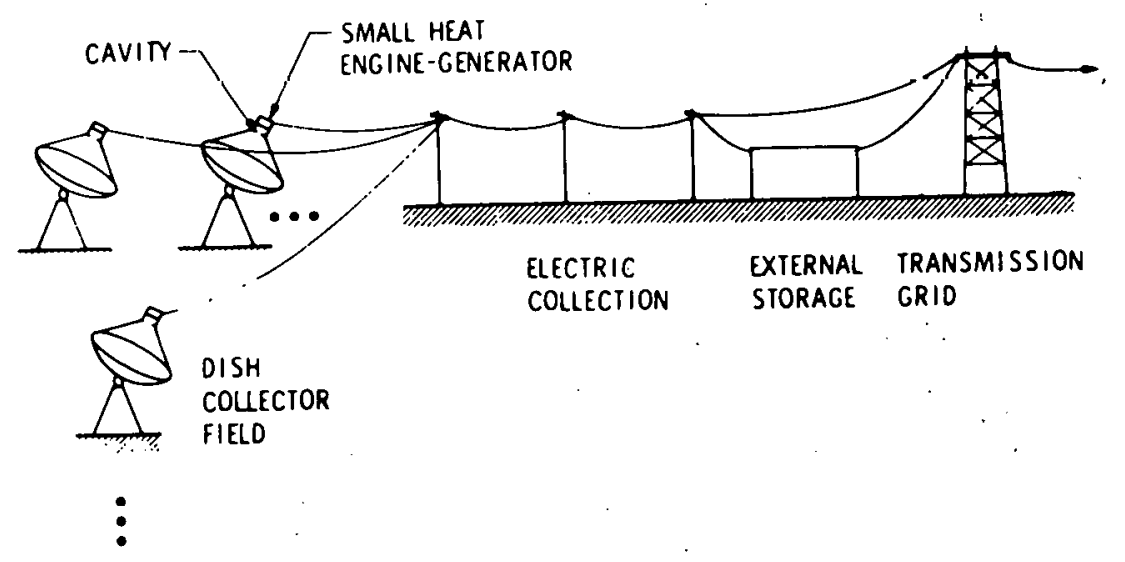

Figure 3-5. Parabolic Dish Collector With Electric Transport System 
Cost data for distributed collectors, using data in 1975 dollars from Reference 3 and inflating the costs to 1977 dollars for consistency with the cost data for central receivers, are presented in Figure 3-6. These data are for a plant startup date in the year 2000 and

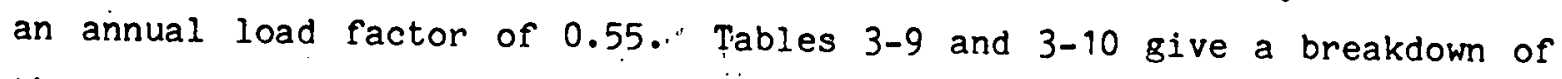
the energy costs from Reference 3 (inflated to 1977 dollars) for $10 \mathrm{MW}_{\mathrm{e}}$ and $100 \mathrm{MW}$ plants of various types, the only two power levels for which specific information is available in Reference 3.

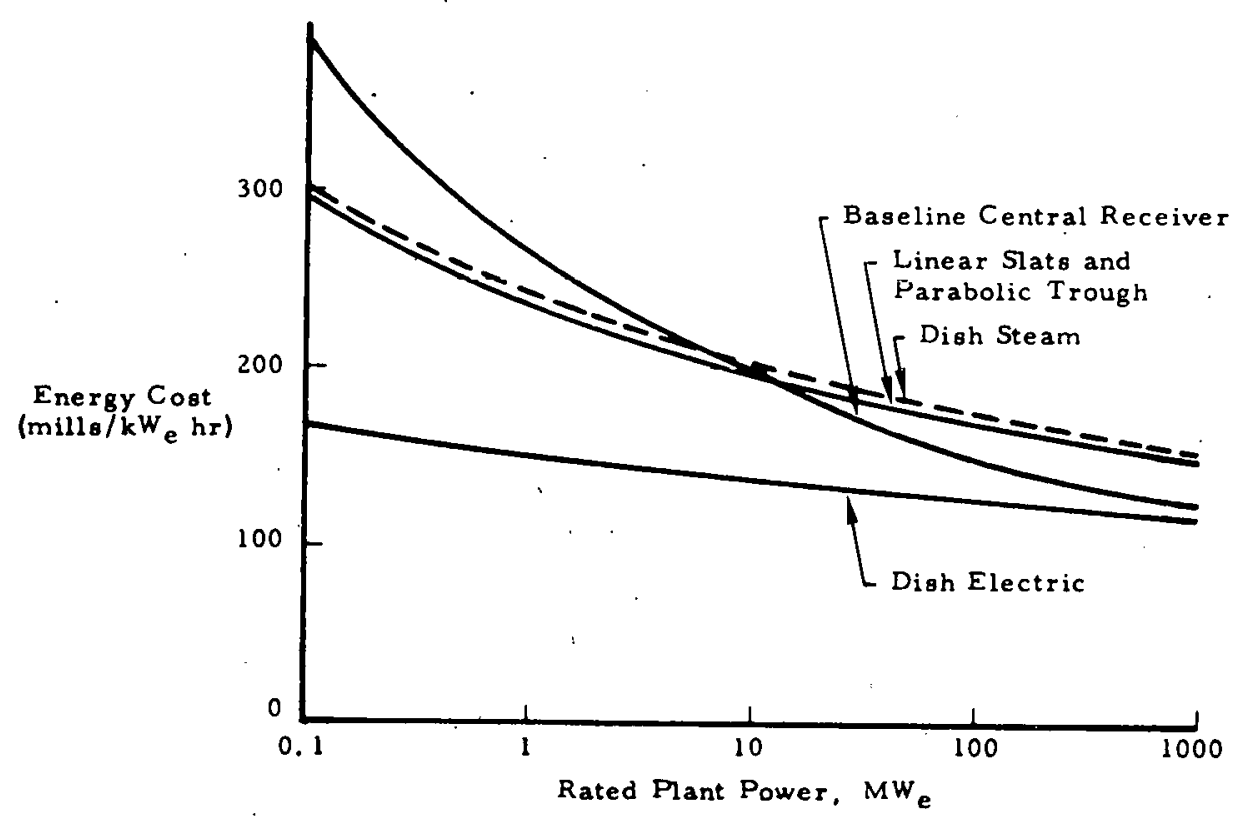

Figure 3-6. Effect of Plant Size apd Type on Energy Cost

\subsection{CHARACTERISTICS OF SMALL FOSSIL-FUELED POWER PLANTS}

Small, fossil-fueled steam plants are no longer being installed by U.S. utility systems pecause they are not cost-effective in comparison to the large steam plants whiph are currently being installed by the utility industry. Those small steam plants which are still in 
Table 3-9. Energy Cost Breakdown, $10 \mathrm{MW}$ Plant Annual Load Factor $=0.55$

Year 2000 Startup

\begin{tabular}{|c|r|r|r|r|}
\hline \multirow{2}{*}{ Item } & \multicolumn{3}{|c|}{ Energy Cost, mills/kW $\mathrm{hr}(1977$ \$) } \\
\cline { 2 - 5 } & $\begin{array}{c}\text { Dish } \\
\text { Electric }\end{array}$ & $\begin{array}{c}\text { Dish } \\
\text { Steam }\end{array}$ & $\begin{array}{c}\text { I-Axis } \\
\text { Slats }\end{array}$ & $\begin{array}{c}\text { Central } \\
\text { Receiver }\end{array}$ \\
\hline Direct Capital & & & & \\
Collectors & 65.5 & 99.1 & 99.1 & 95.0 \\
Transport & 2.4 & 13.0 & 8.3 & 13.6 \\
Conversion & 10.6 & 16.5 & 16.5 & 15.9 \\
Storage & 5.9 & 11.8 & 11.8 & 11.8 \\
Other Capital & 24.8 & 44.3 & 44.8 & 46.6 \\
O\&M & 24.2 & 20.7 & 20.1 & 20.1 \\
\hline Total & 133 & 205 & 200 & 203 \\
\hline
\end{tabular}

Table 3-10. Energy Cost Breakdown, $100 \mathrm{MW}$ e Plant Annual Load Factor $=0.55$ Year 2000 Startup

\begin{tabular}{|c|r|r|r|r|}
\hline \multirow{2}{*}{ Item } & \multicolumn{3}{|c|}{ Energy Cost, mills/kW $\mathrm{k}$ hr (1977 \$) } \\
\cline { 2 - 5 } & $\begin{array}{c}\text { Dish } \\
\text { Electric }\end{array}$ & $\begin{array}{c}\text { Dish } \\
\text { Steam }\end{array}$ & $\begin{array}{c}\text { I-Axis } \\
\text { Slats }\end{array}$ & $\begin{array}{c}\text { Central } \\
\text { Receiver }\end{array}$ \\
\hline Direct Capital & &. & & \\
Collectors & 65.5 & 89.7 & 89.7 & 69.6 \\
Transport & 3.5 & 14.2 & 8.9 & 11.8 \\
Conversion & 10.6 & 11.8 & 11.8 & 11.8 \\
Storage & 5.9 & 11.8 & 11.8 & 11.8 \\
Other Capital & 15.9 & 22.1 & 26.6 & 26.0 \\
O\&M & 24.2 & $:$ &. &. \\
\hline Total & 125.9 & 20.1 & .18 .9 \\
\hline
\end{tabular}


operation are, in general, at least 20 years old. When they are finally phased out by the small utility systems (neglecting, for the moment; the potential impact of solar or other advanced power systems), it is highly probable that they will either be replaced by large steam plants, which would be partly owned by the small utility systems, or else they will not be replaced"at all. In the latter case, the utility system would purchase its power from a large utility company and distribute the power to its users. Since it is extremely unlikely that new installations of small steam plants will occur in the future in the U.S. utility system. the cost data presented in Section 3.3.1 for such plants are for analysis purposes only. The heat rate data for these plants, however, are used to determine the fossil fuel savings which would accrue if such plants were repowered or replaced by small solar thermal power plants.

It should be noted here, however, that small, fossil-fueled steam plants are st1ll being installed by industry, primarily for cogeneration. Information on small fossil-fueled power plants in industrial use has been obtained from the Federal Energy Regulatory Commission's Form 4 and Form 12C Reports. This information will be processed and analyzed in the follow-on study to determine the future market potential for small solar thermal power systems in the industrial sector.

Diesel generators represent the largest segment of the fossil-fueled, small power units in the United States. There is an active market in both new and used units in the low megawatt capacity range. These units are belng used primarily by small municipal utility systems to expand their generating capacity, either by replacing small $\left(\leqslant 300 \mathrm{~kW}_{\mathrm{e}}\right)$, obsolete diesel units or by installing additional units in the system. Because of their low capital cost, diesel generators are very likely to continue to be purchased by small municipal utility systems for the foreseeable future. 
Small gas turbines represent just over one percent of the small power units in the U.S. utility systems. Most of these turbines belong to large utility systems which use them to satisfy peak power requirements. Because of their limited utilization in the small power system segment of the U.S. utility system, no analysis has been conducted of the potential market for small solar thermal power systems in the gas turbine sector. The data shown in section 3.3 .3 are for information purposes only.

\subsubsection{Characteristics of Small Steam-Electric Plants}

As pointed out in Section 3.3, fossil-fueled steam-electric plants under $10 \mathrm{MW}$ in generating capacity have not been installed in any U.S. utility system for at least 15 years. In fact, data in the FEA Inventory of U.S. power plants (Reference 5) indicate that most of these plants are at least 30 years old. The majority of these plants burn either oil or gas as the primary fuel with the other fuel being the alternate. Relatively few of these small plants burn coal as the primary fuel.

While data do exist in the Federal Power Commission (now FERC) archives on the cost and performance of small steam-electric plants in utility systems, these data were unavailable to The Aerospace Corporation. FERC non-cost data from Reference 8 are only available on coal-, oll-, and gas-fired steam plants ranging in generating capacity from 22 to $99 \mathrm{MW}_{\mathrm{e}}$ and installed between 1959 and 1969. These data are tabulated in Table 3-11 for 19 such plants, some of which Involve multiple generating units. Figures $3-7$ and $3-8$ show the costs of such coal- and oll-fired steam plants, respectively, as a function of plant size. These figures also include data on gas-fired and dual fuel (i.e., coal/gas and o1l/gas) steam plants. The original FERC cost data in current year dollars have been adjusted by The Aerospace Corporation to 
Table 3-11. Small Steam Electric Plant Data

\begin{tabular}{|c|c|c|c|c|c|c|}
\hline Name of Plant & Type & Location & $\begin{array}{c}\text { Year of } \\
\text { Operations }\end{array}$ & $\left(\begin{array}{c}\text { Generation } \\
\text { Capacity }\left(\mathrm{MW}_{\mathrm{e}}\right)\end{array}\right.$ & Units & $\begin{array}{c}\text { Heat } \\
\text { Rate } \\
(\mathrm{Btu} / \mathrm{kWh})\end{array}$ \\
\hline $\begin{array}{l}\text { Robert Reid } \\
\text { Nucla } \\
\text { Marion } \\
\text { Ben French } \\
\text { Tombigee } \\
\text { Wisdom } \\
\text { Montpelier }\end{array}$ & $\begin{array}{c}\text { Coal } \\
\text { Coal } \\
\text { Coal } \\
\text { Coal } \\
\text { Coal/Gas } \\
\text { Coal/Gas } \\
\text { Coal/Gas }\end{array}$ & $\begin{array}{l}\text { Sebree, KY } \\
\text { Nucla, CO } \\
\text { Marion, IL } \\
\text { Rapid City, OH } \\
\text { Leroy, AL } \\
\text { Spencer, IA } \\
\text { Montpelier, IA }\end{array}$ & $\begin{array}{l}1965 \\
1959 \\
1963 \\
1960 \\
1969 \\
1960 \\
1960\end{array}$ & $\begin{array}{r}80 \\
35 \\
99 \\
22 \\
75 \\
38 \\
63\end{array}$ & $\begin{array}{l}1 \\
3 \\
3 \\
1 \\
1 \\
1 \\
2\end{array}$ & $\begin{array}{l}11,285 \\
14,407 \\
12,620 \\
13,093 \\
10,861 \\
12,990 \\
11,735\end{array}$ \\
\hline $\begin{array}{l}\text { Cleary, B. F. } \\
\text { Thomas Fitzhugh } \\
\text { Olive Ave } \\
\text { McPherson No. } 2 \\
\text { Pathfinder } \\
\text { Sunrise }\end{array}$ & $\begin{array}{l}\text { Oil } \\
\text { Oil/Gas } \\
\text { Oil/Gas } \\
\text { Oil/Gas } \\
\text { Oil/Gas } \\
\text { Oil/Gas }\end{array}$ & $\begin{array}{l}\text { Taunton, MA } \\
\text { Ozark, AR } \\
\text { Burbank, CA } \\
\text { McPherson, KS } \\
\text { Sioux Falls, SD } \\
\text { Las Vegas, NV }\end{array}$ & $\begin{array}{l}1966 \\
1963 \\
1959 \\
1963 \\
1969 \\
1964\end{array}$ & $\begin{array}{l}28 \\
60 \\
99 \\
32 \\
75 \\
82\end{array}$ & $\begin{array}{l}1 \\
1 \\
2 \\
1 \\
1 \\
1\end{array}$ & $\begin{array}{r}13,002 \\
11,570 \\
11,926 \\
12,735 \\
13,965 \\
9,949\end{array}$ \\
\hline $\begin{array}{l}\text { Apache } \\
\text { Cimmaron River } \\
\text { Lea County } \\
\text { Oak Creek } \\
\text { Miller RW } \\
\text { Pearsall Texas }\end{array}$ & $\begin{array}{l}\text { Gas } \\
\text { Gas } \\
\text { Gas } \\
\text { Gas } \\
\text { Gas } \\
\text { Gas }\end{array}$ & $\begin{array}{l}\text { Cochise, AZ } \\
\text { Liberal, KS } \\
\text { New Mexico } \\
\text { Bronte, TX } \\
\text { Gordon, TX } \\
\text { Pearsall, TX }\end{array}$ & $\begin{array}{l}1964 \\
1963 \\
1962 \\
1962 \\
1968 \\
1961\end{array}$ & $\begin{array}{l}93 \\
65 \\
57 \\
82 \\
75 \\
75\end{array}$ & $\begin{array}{l}2 \\
2 \\
2 \\
1 \\
1 \\
1\end{array}$ & $\begin{array}{l}10,094 \\
12,168 \\
12,587 \\
10,133 \\
10,705 \\
12,089\end{array}$ \\
\hline
\end{tabular}




\begin{tabular}{|c|c|}
\hline Symbol & \multicolumn{1}{|c|}{ Description } \\
\hline 0 & Coal-Fired: FPC Data (24th Supp) - Actual \\
0 & Coal/Gas-Fired: FPC Data, Actual \\
\hline
\end{tabular}

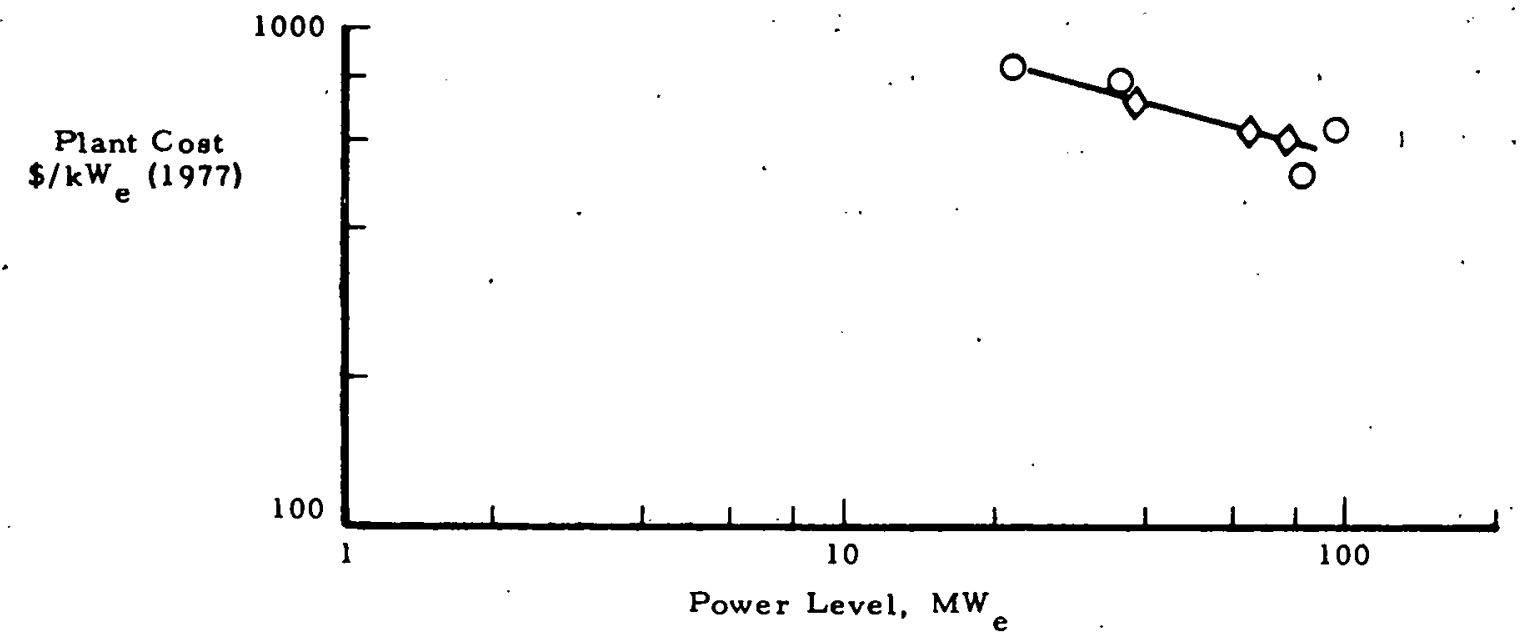

Figure 3-7. Costs of Coal-Fired Steam-Electric Plants

\begin{tabular}{|c|c|}
\hline Symbol & \multicolumn{1}{|c|}{ Description } \\
\hline 0 & Oil-Fired; FPC Mata, (24th Supp) - Artual \\
$\diamond$ & Oil/Gas-Fired: FPC Data, Actual \\
\hline
\end{tabular}

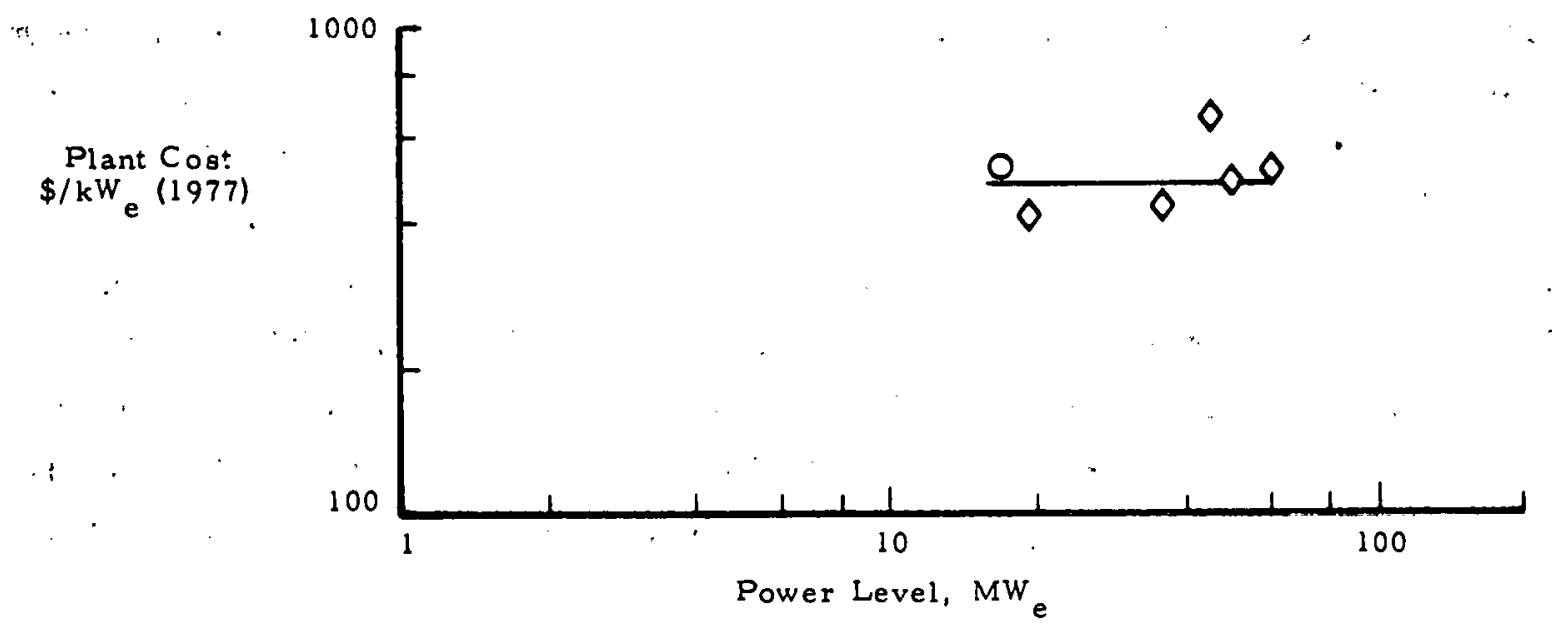

Figure 3-8. Costs of Oil-Fired Steam-Electric Plants 
1977 doliars using the Handy-Whltman Index (Reference 9). The costs were also adjusted to cover the cost of $\mathrm{SO}_{2}$ stack gas cleanup equipment which was not required: when the plants: were built, but which would be required today. The $\mathrm{SO}_{2}$ cleanup costs were obtalned from stearns Roger, Inc. and are based on cost estimates prepared by them in support of MoDonnell Douglas. The costs were applled equally to both coal- and o1l-f1red steam plants at the rate of $\$ 100 / \mathrm{kW}_{e}$, which represents an average of Stearns Roger estimates for varying sulfur content in coal. Since oll normally contains less sulfur than coal, the costs shown for o1l-rired steam plants are probably slightly high.

Figure 3-9 shows the heat rate values for different types of foss1l-fueled, small power systems. (1.e., steam turbines, diesel generators, and gas turbines) as a funotion of the generating capacity of the generating unit. The three curves are based on data prepared by Power Technologles, Inc. (Reference 10) for the Electrlo Power Research Institute (EPRI). The four data points for diesel generators are for a single brand of generator currently in production and widely used by ut1lity systems in the U.S. The data points for the steam-electric plants shown in the figure were taken directly from data presented in Reference 8 for the 19 steam-electric plants included in Table 3-11. One additional data point was obtained for a $6.6 \mathrm{MW}$ coal-burning steam plant Installed in Raton, New Mexico in 1962. The data for this plant are indirect, being based on an average welght of 1.47 lb of coal to produce one kWh and an average heating value of 11,200 Btu/lb for coal supplied to the plant by the General. Energy Corporation of Florence, Colorado. The average heat rate corresponds to $16,400 \mathrm{Btu} / \mathrm{kWh}$. When one considers that a large $\left(\geq 100 \mathrm{MW}_{e}\right)$ coal-burning steam-electric plant has a heat rate of the order of $10,000 \mathrm{Btu} / \mathrm{kWh}$, it is not difficult to understand why small steam plants are no longer being installed by U.S. ut1lity systems. 


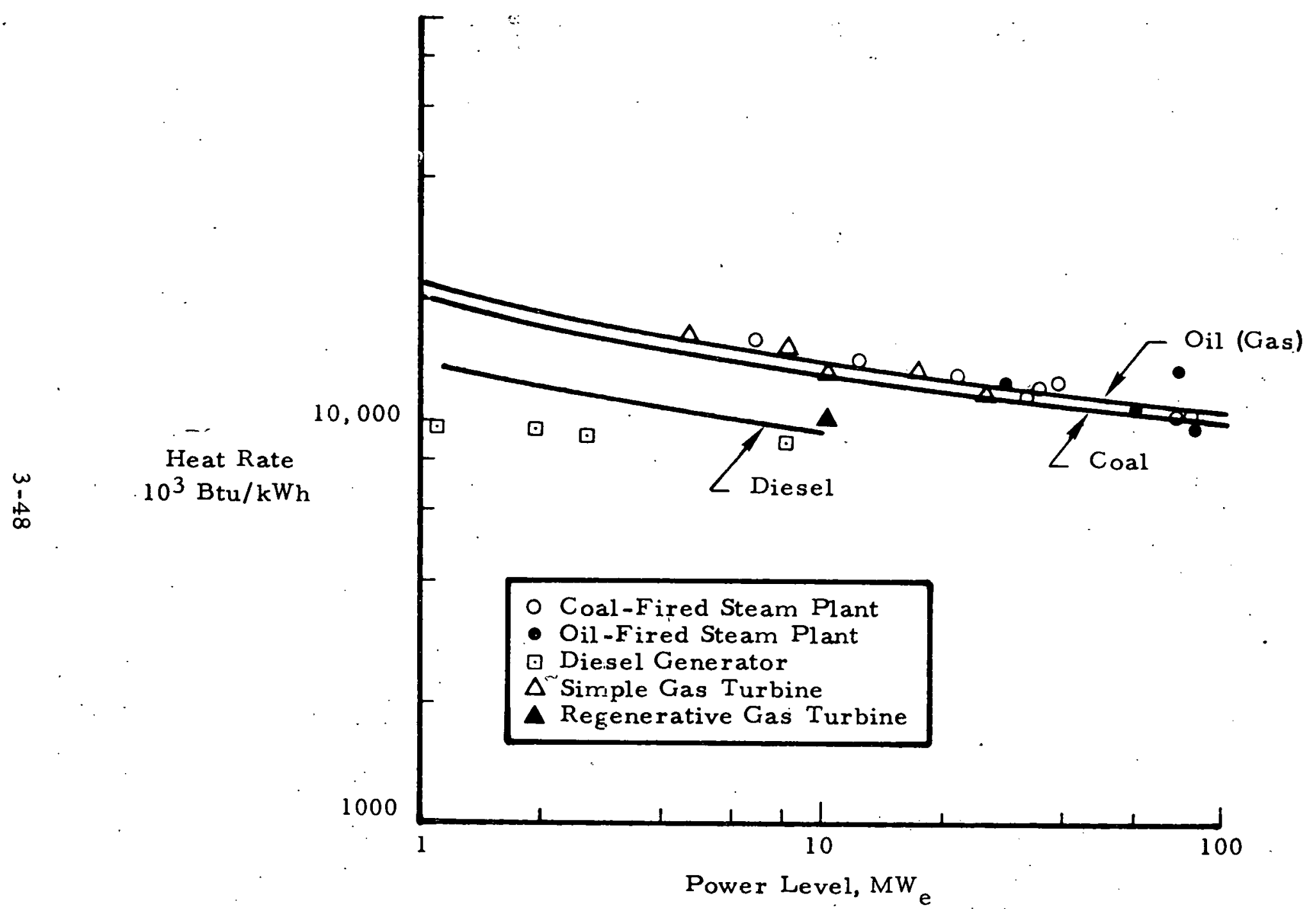

Figure 3-9. Heat Rates for Steam Plants and Diesel Generators 


\subsubsection{Characteristics of Diesel Generator Units}

Most of small electrical generating units in service in U.S. utility systems today are diesel generators, as indicated in Table 3-2. Table 3-6 (pages 3-19, -20) shows the distribution of the 3243 diesel generators, which comprise approximately 84 percent of the small generating units in the U.S., by state and by generating capacity. The table also gives the numerical and percentage distribution for the entire United States.

\subsubsection{Age}

The FEA inventory of U.S. power plants (Reference 5) includes data on the installation date of the individual generating units. For units under $1 \mathrm{MW}$ in capacity, it is necessary to correlate the data with the Electrical World Directory (Reference 4) to identify the unit number. A detailed correlation has not been performed of the generating capacity and age of all U.S. diesel generators, but spot checks have been made for Nebraska and Texas. This check indjcates that most of the diesel generators under $.400 \mathrm{~kW}_{\mathrm{e}}(\sim 19$ percent) are at least 35 years old. A large number of the additional 30 percent of U.S. diesels with capacities under $1 \mathrm{MW}$ are 25-30 years old. Another 26 percent of the diesels are in the 1-2 $\mathrm{MW}_{\mathrm{e}}$ range and, by 1985, most of these generators will be 30-35 years old, as will a number of diesels in the 2-3 $\mathrm{MW}_{\mathrm{e}}$ range.

If the utility systems which currently have diesel generators in service continue to generate their own power in the future, there will be a large, continuing market for replacement diesel generators and/or advanced power systems. Most of the replacement diesel units will probably be greater. than one megawatt in capacity, possibly in 
the 2-4 MW range, and diesel generators with less than one megawatt of capacity should gradually disappear.

\subsubsection{Fuel}

No attempt has been made to correlate fuel type with the number or size of diesel generators in service. However, it is safe to say that, prior to 1973, most of the diesels either operated on natural gas or had a dual fuel capability. Even with today's restricted supply of naturaj. gas, most of the diesels which are still capable of using natural gas will do so when the gas is avallable because it is still cheaper than No. 2 fuel oll on an energy basis. In the course of conducting telephone tinterviews with a number of small utility systems, It was pointed out that the relative costs of natural gas and oil are very close in a few locations in the Southwest, such as Clayton, New Mexico, and that the cholce of fuel is no longer an important cost factor. On the other hand, the city of Tulla, Texas, and the Lea County Electric Cooperative in Lovington, New Mexico, believe that gas will continue to be available at a lower price than ofl on an energy basis and they intend to operate on gas as long as possible. A number of municlpal utility systems in Oklahoma now operate their diesel generators only in the summer when natural gas is avallable; in this manner they can supply peak power demands at a lower cost and buy power from a major utility system to meet the remainder of their power requirements.

In addition to the avallability and relative cost of natural gas, state regulations regariing the use of natural gas by utility systems appear to differ. In Texas, any ut1jity system consuming less than three million cubic feet per day of natural gas can continue to burn Bas. In other states, such as New Mextco, the utilities are being forced to phase out their gas consumption over the next few years and to switch to other fuels, usually o1l. Although no information has been sought 
from utilities on this issue, an attempt will be made in the follow-on study to determine those conditions under which a utility system would either consider ceasing its own power generation and purchasing all of its power from a major utility, or else would switch to a different type of generating system, such as solar thermal or a coal-fired steam plant.

\subsubsection{Performance and Cost}

In the past, the electric energy costs to customers supplied by diesel electric plants have generally been quite competitive with the cost, of electricity generated by large steam-electric plants using coal, oll, gas, or nuclear fuels. Shortages of natural gas and rising fuel prices since 1973 have resulted in shifts from gas to No. 2 fuel ofl for a number of utility systems and in the cessation of power generation by some municipal utility systems. Nevertheless, the performance of diesel generators is sufficiently attractive to represent a viable option for generating utilities, especially when one considers the low capital cost of diesels compared to other types of power generation equipment.

Data gathered from a number of manufacturers of diesel generating equipment indicate that diesel generators with capacities as low as $50 \mathrm{~kW}_{e}$ are extremely efficient and have heat rates as low as or lower than large ( $\left.\geqslant 100 \mathrm{MW}_{e}\right)$ steam plants, as shown in Figure 3-9. The reliability of diesel generators is excellent and they are routinely capable of operating from :20,000 to 30,000 hours between overhauls. Large diesel generators intended specifically for power plant operation are designed to run at relatively low speeds in order to increase the number of hours between overhauls and to extend the useful operating ilfetime of the equipment. The older diesel generators, which either are being phased out or will be phased out over the next several years, have poorer performance and, in some cases, are extremely. difficult to. find replacement parts for. 
The capital cost per kilowatt hour of diesel generators as a function of generating capacity is plotted in Figure 3-10. Variations in

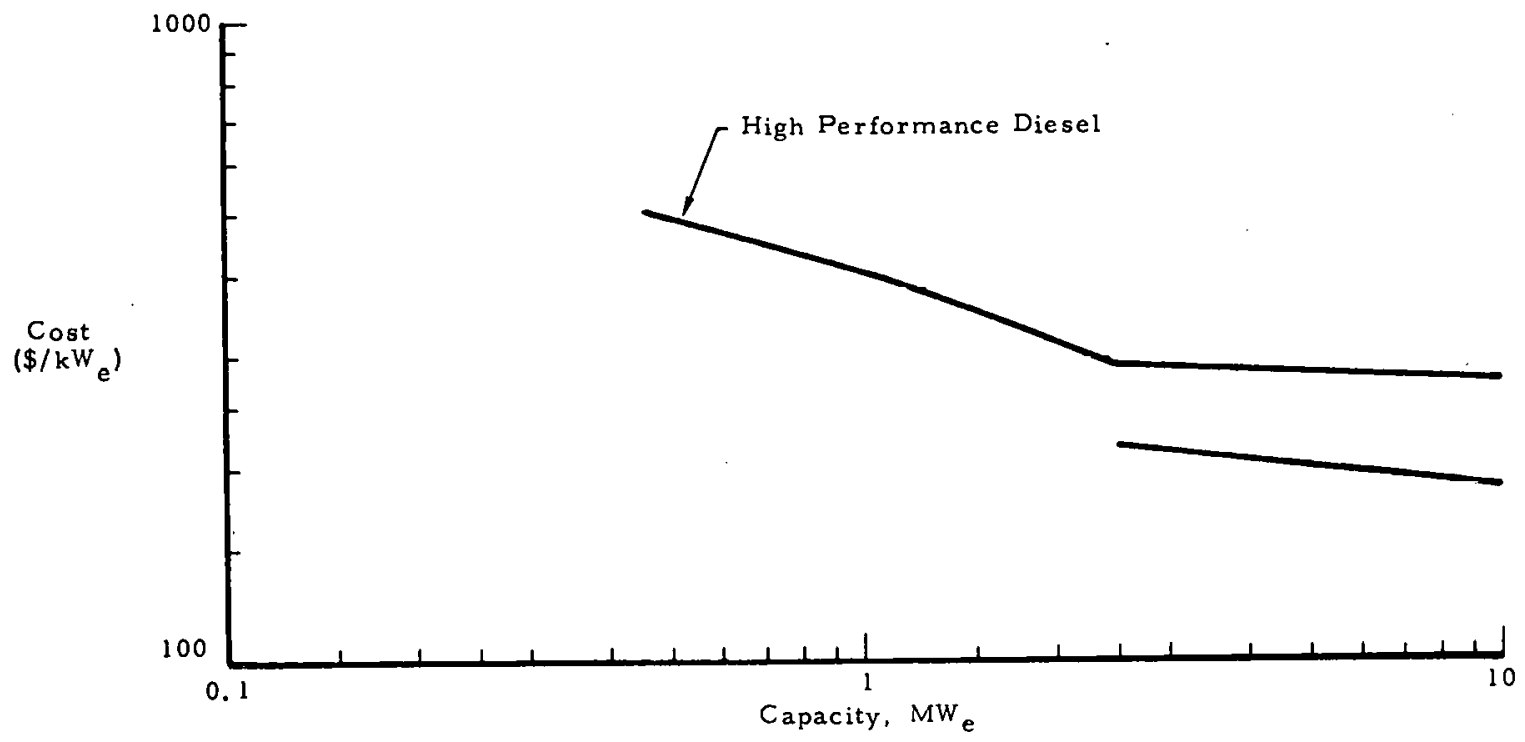

Figure 3-10. Capital Costs of Diesel Generators

cost per kilowatt for a specific generating capacity occur because of differences in the design requirements of units manufactured by different companies. Low speed units cost more than higher speed units, but last longer and require less maintenance. Higher performance (i.e., lower heat rates) units cost more initially than units with lower performance, but recover the difference in costs in a relatively short time because of improved fuel economy. On the basis of the limited number of telephone interviews with small utility systems and a large number of contacts made to verify data for the inventory of small generating units in the United States reported in Volume II of this Report, it is evident that almost all of the diesel equipment currently being installed by U.S. utility systems is high performance equipment. Consequently, the performance and cost parameters used in the breakeven financial analysis are for a specific manufacturer of high performance, commercially available diesel equipment currently being purchased by a number of utijity systems. 


\subsubsection{Characteristics of Gas Turbines}

Only 45 of the 3869 small electrical generating units in the U.S. utility system are gas turbines. Normally, a gas turbine is used by a large utility system to produce peak power and is larger than $10 \mathrm{MW}_{\mathrm{e}}$ in capacity. In view of the small sample size and the gas turbine!s inefficient performance for baseload or intermediate power generation, it was decided that no breakeven financial analysis would be carried out for gas turbines. It should be noted in passing that gas turbines have the lowest capital cost of any type of generating unit, but that they consume more fuel than competing systems of the same size. However, the limited amount of performance and cost data on commercially available gas turbines accumulated prior to the decision to neglect gas turbines in the analysis is presented here for information purposes. The performance data are shown in Figure 3-9 and the cost data are plotted in Figure 3-11.

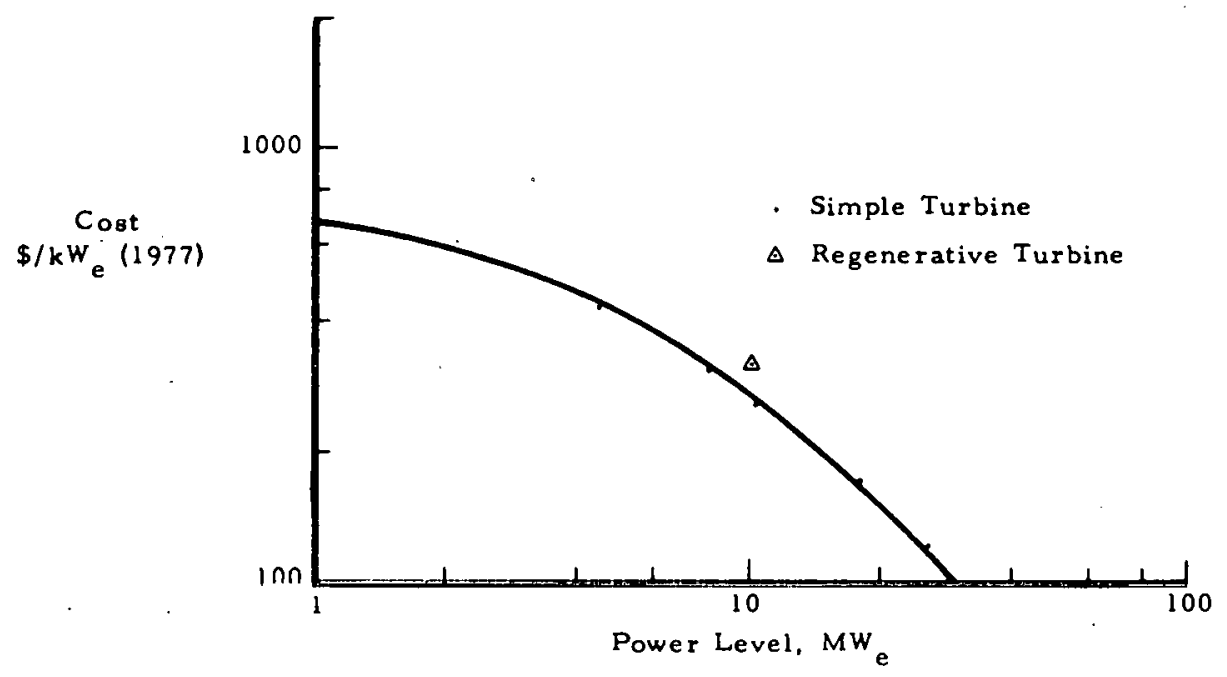

Figure 3-11. Gas Turbine Costs 


\section{$3.4 \quad$ INSOLATION DATA}

Direct-normal insolation data are required for the breakeven financial analyses described in Section 4. The approach selected for the initial set of breakeven analyses of five southwestern "sun belt" states was to use Inyokern, California, as the baseline location and to ratio the direct insolations for the other four states to Inyokern. Where a choice of locations with insolation data existed for any of the four states, a city was selected with a high direct-normal insolation (e.g., El Paso rather than Fort Worth, Texas) in order to pick a favorable location for a solar thermal power system. The five states, the reference, cities, and their annualized average daily direct insolations are shown in Table 3-12. Capacity factors, based on an Inyokern value of 0.250 , are also shown in the table.

The insolation data for all locations except Inyokern are based on the revised data base, Data Base II, prepared by the National

Table 3-12. Locations and Insolation Values for Breakeven Analyses

\begin{tabular}{|l|l|c|c|}
\hline \multicolumn{1}{|c|}{ State } & \multicolumn{1}{|c|}{ City } & $\begin{array}{c}\text { Average Daily } \\
\text { Direct Insolation } \\
\left(\mathrm{kWh} / \mathrm{m}^{2} / \text { day }\right)\end{array}$ & $\begin{array}{c}\text { Capacity } \\
\text { Factor }\end{array}$ \\
\hline California & Inyokern & 7.85 & 0.250 \\
Texas & E1 Paso & 7.26 & 0.231 \\
New Mexico & Albuquerque & 7.13 & 0.227 \\
Arizona & Phoenix & 6.92 & 0.220 \\
Nevada & Ely & 6.63 & 0.211 \\
\hline
\end{tabular}

Oceanographic and Atmospheric Administration (NOAA) from 1952-1975 insolation data gathered by the National Weather Service. These revised 
data differ from the earlier insolation data in the following respects: (1) the values for total hemispheric insolation have been adjusted by the NOAA to correct for calibration error and instrument drift, (2) the values for direct normal insolation have been estimated on the basis of improved correlation algorithms, and. (3) many more years of data (typlcally covering the 1952-1975. period) are provided for each location. Reference 11 describes the procedure used in developing the revised insolation data. The Inyokern insolation value was obtained by "correcting" the 1962-1963 original direct-normal insolation data for Inyokern in the following manner. The averages of the original 1962 and 1963 direct-normal insolation values for EI Paso and Phoenix were ratioed to the revised long term average daily direct insolations for these two cities. These two years were selected because the revised average values of the direct-normal insolation for 1962 and 1963 for these two cities agree almost exactly for El Paso and to within one percent for Phoenix with the 1952-1975 revised long term averages for these two clties. The two ratios, were averaged and multiplied by. the average of the 1962 and 1963 annualized dally direct insolation values for Inyokern (1.e., 8.99 $\mathrm{kWh} / \mathrm{m}^{2} /$ day) to give a revised value of $7.71 \mathrm{kWh} / \mathrm{m}^{2} /$ day for Inyokern. This revised value was then averaged with the 1976 annualized dally direct insolation value of $7.99 \mathrm{kWh} / \mathrm{m}^{2} /$ day measured by the Southern California Edison Company at Ridgecrest; California (only a few miles from Inyokern), to yield the direct-normal insolation value of 7.85 $\mathrm{kWh} / \mathrm{m}^{2}$ /day listed in Table 3-12.

The revised direct-normal insolation values are lower than the values used by The Aerospace Corporation in mission analyses conducted prior to :FY 1978 by the following amounts: California-13 percent, Arizona and Texas-14. percent, New Mexico-15 percent, and Nevada-17 percent. 
3.5. FUEL COSTS

Projected fossil fuel costs for the 1985-2015 time period are needed in order to calculate the value of the potential. fuel savings achievable if fossil fuel-burning power plants are replaced or repowered by solar thermal power systems. The fuel savings are used to carry but the breakeven financlal analyses described in Section 4.

Fuel prices for fossil-fueled electric generating units were taken from the Sherman H. Clark Associates report (Reference 7)-prepared for The Aerospace Corporation's study of solar total energy systems (STES). This report projects energy prices by fuel type, state, user sector (e.g., residential or industrial), and period of use. The rationale used by Sherman $H$. Clark in making the prices projections is contained in their report. Historical energy cost data were taken from Federal Power Commission, Federal Energy Administration, and Department of Commerce reports. The Sherman H. Clark data were used in preference to other data sources in order to maintain consistency with the two other Aerospace Corporation studies on dispersed power systems (1.e., STES and solar-powered irrigation systems) and because these projections appear to be more thorough than other available projections.

Table 3-13, which shows 1974-1975 prices by state for No. 2 fuel ot? used in all types of fossil-fueled generating units, is taken from Table III-3 of Reference 7. Table 3-14 lists natural gas prices for the five southwestern "sun belt" states and is extracted from Table III-14 of Reference 7. Tables 3-15 through 3-19 give energy prices taken from Tables III-123, $-114,-120,-115$, and -119 of Reference 7 for California, Texas, New Mexico, Arizona, and Nevada, respectively. Since Sherman Clark did not project natural gas prices for power plants into the 1985-2015 time period (due to the general unavailability of gas for this application in that period), the clark cost projections for 
Table 3-13. Prices of No. 2 Fuel Oil Deliveries, to Steam-Electric Plants

\begin{tabular}{|c|c|c|}
\hline \multirow{2}{*}{ Census Regions } & \multicolumn{2}{|c|}{$\begin{array}{l}\text { Prices } \\
\text { (Dollars/barrel) }\end{array}$} \\
\hline & 1974 & 1975 \\
\hline $\begin{array}{l}\text { New England } \\
\text { Connecticut } \\
\text { Maine } \\
\text { Massachusetts } \\
\text { New Hampshire } \\
\text { Rhode Island } \\
\text { Vermont }\end{array}$ & $\begin{array}{c}\$ 12.00 \\
13.28 \\
-- \\
11.89 \\
-- \\
12.60 \\
--\end{array}$ & $\begin{array}{c}\$ 12.98 \\
13.41 \\
-- \\
12.96 \\
-- \\
11.91 \\
--\end{array}$ \\
\hline $\begin{array}{l}\text { Middle Atlantic } \\
\text { New Jersey } \\
\text { New York } \\
\text { Pennsylvania. }\end{array}$ & $\begin{array}{c}13.30 \\
-- \\
12.90 \\
13.35\end{array}$ & $\begin{array}{c}12.73 \\
-- \\
11.76 \\
13.72\end{array}$ \\
\hline $\begin{array}{l}\text { East North.Central } \\
\text { Illinois } \\
\text { Indiana } \\
\text { Michigan } \\
\text { Ohio } \\
\text { Wisconsin }\end{array}$ & $\begin{array}{l}10.82 \\
10.88 \\
10.11 \\
11.26 \\
12.40 \\
11.92\end{array}$ & $\begin{array}{l}12.31 \\
12.16 \\
12.41 \\
11.79 \\
13.26 \\
13.07\end{array}$ \\
\hline $\begin{array}{l}\text { West North Central } \\
\text { Iowa } \\
\text { Kansas } \\
\text { Minnesota } \\
\text { Missouri } \\
\text { Nebraska } \\
\text { North Dakota } \\
\text { South Dakota }\end{array}$ & $\begin{array}{r}12.21 \\
9.84 \\
12.18 \\
12.78 \\
12.99 \\
8.47 \\
11.95 \\
--.\end{array}$ & $\begin{array}{l}12.55 \\
11.73 \\
12.24 \\
13.11 \\
13.28 \\
10.46 \\
12.37 \\
13.44\end{array}$ \\
\hline $\begin{array}{l}\text { South Atlantic } \\
\text { Delaware } \\
\text { Florida } \\
\text { Georgia } \\
\text { Maryland and Washington, D.C. } \\
\text { North Carolina } \\
\text { South Carolina } \\
\text { Virginia } \\
\text { West Virginia }\end{array}$ & $\begin{array}{l}12.25 \\
12.09 \\
10.72 \\
12.11 \\
11.26 \\
13.38 \\
13.39 \\
12.24 \\
13.28\end{array}$ & $\begin{array}{l}13.02 \\
12.67 \\
12.96 \\
13.12 \\
12.56 \\
12.91 \\
13.32 \\
13.00 \\
13.62\end{array}$ \\
\hline
\end{tabular}


Table 3-13. Prices of No. 2 Fuel Oil Deliveries to Steam-Electric Plants (Cont'd).

\begin{tabular}{|c|c|c|}
\hline \multirow{2}{*}{ Census Regions } & \multicolumn{2}{|c|}{$\begin{array}{c}\text { Prices } \\
\text { (Dollars/barrel) }\end{array}$} \\
\hline & 1974 & 197.5 \\
\hline $\begin{array}{l}\text { East South Central } \\
\text { Kentucky } \\
\text { Tennessee } \\
\text { Alabama } \\
\text { Mississippi }\end{array}$ & $\begin{array}{r}\$ 12.24 \\
12.81 \\
15.39 \\
11.86 \\
12.20\end{array}$ & $\begin{array}{r}\$ 12.35 \\
12.99 \\
13.24 \\
12.58 \\
12.12\end{array}$ \\
\hline $\begin{array}{l}\text { West South Central } \\
\text { Oklahoma } \\
\text { Arkansas } \\
\text { Louisiana } \\
\text { Texas }\end{array}$ & $\begin{array}{r}14.68 \\
9.66 \\
11.76 \\
18.71 \\
10.94\end{array}$ & $\begin{array}{l}11.98 \\
11.23 \\
12.71 \\
11.55 \\
12.71\end{array}$ \\
\hline $\begin{array}{l}\text { Mountain } \\
\text { Arizona' } \\
\text { C.olorado } \\
\text { Idaho } \\
\text { Montana } \\
\text { Nevada } \\
\text { New Mexico } \\
\text { Utah } \\
\text { Wyoming }\end{array}$ & $\begin{array}{c}12.32 \\
12.30 \\
13.44 \\
-- \\
-- \\
12.98 \\
12.16 \\
13.16 \\
13.78\end{array}$ & $\begin{array}{c}1.3 .35 \\
13.26 \\
13.68 \\
-- \\
-- \\
14.38 \\
10.83 \\
13.58 \\
14.33\end{array}$ \\
\hline $\begin{array}{l}\text { Pacific } \\
\text { California } \\
\text { Oregon } \\
\text { Washington }\end{array}$ & $\begin{array}{l}11.60 \\
10.83 \\
12.89 \\
--\end{array}$ & $\begin{array}{l}12.96 \\
13.80 \\
11.87 \\
-.-\end{array}$ \\
\hline $\begin{array}{l}\text { Total United States (excluding } \\
\text { Alaska and Hawaii) }\end{array}$ & 12.63 & 12.54 \\
\hline
\end{tabular}

Source: FPC, Annual Summary of Cost and Quality of Steam-Electric Plant Fuels, 1974, and 1975. 
Table 3-14. Natural Gais Prices in "Sun Belt" States

\begin{tabular}{|c|c|c|c|c|c|c|c|c|c|}
\hline \multirow[b]{3}{*}{ State } & \multicolumn{9}{|c|}{ Prices in Dollars/Thousand Cubic Feet } \\
\hline & \multirow[b]{2}{*}{$\begin{array}{l}\text { City } \\
\text { Gate } \\
\text { Price }\end{array}$} & \multicolumn{4}{|c|}{ Distributor Margin } & \multicolumn{4}{|c|}{ Consumer Price } \\
\hline & & $\begin{array}{l}\text { Powcr } \\
\text { Plants } \\
\text { and } \\
\text { Other }\end{array}$ & Industrial & Commercial & Residential & $\begin{array}{c}\text { Power } \\
\text { Plants } \\
\text { and } \\
\text { Other }\end{array}$ & Industrial & Commercial & Residential \\
\hline $\begin{array}{r}\text { Ariznna } \\
1975 \\
1976 \\
1985 \\
1990 \\
1995 \\
2000 \\
2005 \\
2010 \\
2015 \\
\end{array}$ & \begin{tabular}{|r|}
$\$ 0.77$ \\
0.90 \\
1.90 \\
3.33 \\
4.18 \\
4.66 \\
4.70 \\
4.61 \\
4.61 \\
\end{tabular} & $\begin{array}{c}\$ 0.01 \\
0.10 \\
-- \\
-- \\
-- \\
-- \\
-- \\
-- \\
-\end{array}$ & $\begin{array}{l}(0.01) \\
(0.07) \\
0.09 \\
0.11 \\
0.14 \\
0.17 \\
0.21 \\
0.27 \\
0.33 \\
\end{array}$ & $\begin{array}{r}\$ 0.41 \\
0.47 \\
0.49 \\
0.50 \\
0.52 \\
0.53 \\
0.54 \\
0.56 \\
0.57 \\
\end{array}$ & $\begin{array}{l}\$ 0.76 \\
0.88 \\
0.87 \\
0.87 \\
0.86 \\
0.86 \\
0.86 \\
0.85 \\
0.85 \\
\end{array}$ & $\begin{array}{c}\$ 0.78 \\
1.00 \\
-- \\
-- \\
-- \\
-- \\
-- \\
-- \\
\end{array}$ & $\begin{array}{r}\$ n .76 \\
0.83 \\
1.99 \\
3.44 \\
4.32 \\
4.83 \\
4.91 \\
4.88 \\
4.94 \\
\end{array}$ & $\begin{array}{l}\$ 1.18 \\
1.37 \\
2.39 \\
3.83 \\
4.70 \\
5.19 \\
5.24 \\
5.17 \\
5.18 \\
\end{array}$ & $\begin{array}{r}\$ 1.53 \\
1.74 \\
2.77 \\
4.20 \\
5.04 \\
5.52 \\
5.56 \\
5.46 \\
5.46 \\
\end{array}$ \\
\hline $\begin{array}{c}\text { California } \\
1975 \\
1976 \\
1985 \\
1990 \\
1995 \\
2000 \\
2005 \\
2010 \\
2015 \\
\end{array}$ & $\begin{array}{l}0.87 \\
1.12 \\
2.98 \\
3.72 \\
4.44 \\
4.85 \\
4.81 \\
4.74 \\
4.73\end{array}$ & $\begin{array}{c}0.24 \\
0.46 \\
-- \\
-- \\
-- \\
-- \\
-- \\
-- \\
--\end{array}$ & $\begin{array}{l}0.24 \\
0.41 \\
0.45 \\
0.47 \\
0.49 \\
0.52 \\
0.54 \\
0.57 \\
0.60 \\
\end{array}$ & $\begin{array}{l}0.43 \\
0.43 \\
0.47 \\
0.49 \\
0.51 \\
0.54 \\
0.56 \\
0.59 \\
0.62\end{array}$ & $\begin{array}{l}0.70 \\
0.60 \\
0.61 \\
0.62 \\
0.62 \\
0.63 \\
0.64 \\
0.64 \\
0.65\end{array}$ & $\begin{array}{c}1.11 \\
1.58 \\
-- \\
-- \\
-- \\
-- \\
-- \\
- \\
\end{array}$ & $\begin{array}{l}1.11 \\
1.53 \\
3.43 \\
4.19 \\
4.93 \\
5.37 \\
5.35 \\
5.31 \\
5.33\end{array}$ & $\begin{array}{l}1.30 \\
1.55 \\
3.45 \\
4.21 \\
4.95 \\
5.39 \\
5.37 \\
5.33 \\
5.35 \\
\end{array}$ & $\begin{array}{l}1.57 \\
1.72 \\
3.59 \\
4.34 \\
5.06 \\
5.48 \\
5.45 \\
5.38 \\
5.38\end{array}$ \\
\hline $\begin{array}{c}\text { Nevada } \\
1975 \\
1976 \\
1985 \\
1990 \\
1995 \\
2000 \\
2005 \\
2010 \\
2015\end{array}$ & $\begin{array}{l}1.00 \\
1.23 \\
1.30 \\
3.33 \\
4.18 \\
4.66 \\
4.70 \\
4.61 \\
4.61\end{array}$ & $\begin{array}{c}0.24 \\
0.27 \\
-- \\
-- \\
-- \\
- \\
- \\
- \\
--\end{array}$ & $\begin{array}{l}0.13 \\
0.24 \\
0.28 \\
0.30 \\
0.32 \\
0.35 \\
0.38 \\
0.41 \\
0.44\end{array}$ & $\begin{array}{l}0.63 \\
0.71 \\
0.73 \\
0.74 \\
0.75 \\
0.76 \\
0.78 \\
0.79 \\
0.80\end{array}$ & $\begin{array}{l}0.95 \\
0.73 \\
0.74 \\
0.75 \\
0.76 \\
0.77 \\
0.78 \\
0.79 \\
0.80\end{array}$ & $\begin{array}{l}1.24 \\
1.50 \\
-- \\
-- \\
-- \\
-- \\
-- \\
-- \\
--\end{array}$ & $\begin{array}{l}1.13 \\
1.47 \\
2.18 \\
3.63 \\
4.50 \\
5.01 \\
5.08 \\
5.02 \\
5.05\end{array}$ & $\begin{array}{l}1.63 \\
1.94 \\
2.63 \\
4.07 \\
4.93 \\
5.42 \\
5.48 \\
5.40 \\
5.41\end{array}$ & $\begin{array}{l}1.95 \\
1.96 \\
2.64 \\
4.08 \\
4.94 \\
5.43 \\
5.48 \\
5.40 . \\
5.41\end{array}$ \\
\hline \begin{tabular}{|c|} 
New Mexico \\
1975 \\
1976 \\
1985 \\
1990 \\
1995 \\
2000 \\
2005 \\
2010 \\
2015 \\
\end{tabular} & $\begin{array}{l}0.77 \\
1.10 \\
1.90 \\
3.33 \\
4.18 \\
4.66 \\
4.70 \\
4.61 \\
4.61 \\
\end{array}$ & $\begin{array}{c}(0.23) \\
(0.38) \\
-- \\
-- \\
- \\
- \\
-- \\
-- \\
-\end{array}$ & $\begin{array}{l}(0.15) \\
(0.27) \\
0.15 \\
0.17 \\
0.19 \\
0.21 \\
0.24 \\
0.27 \\
0.30 \\
\end{array}$ & $\begin{array}{l}0.23 \\
0.24 \\
0.26 \\
0.27 \\
0.29 \\
0.30 \\
0.32 \\
0.33 \\
0.35 \\
\end{array}$ & $\begin{array}{l}0.56 \\
0.62 \\
0.62 \\
0.61 \\
0.61 \\
0.61 \\
0.60 \\
0.60 \\
0.60\end{array}$ & $\begin{array}{c}0.54 \\
0.72 \\
-- \\
-- \\
- \\
-- \\
- \\
-- \\
--\end{array}$ & $\begin{array}{l}0.62 \\
0.83 \\
2.05 \\
3.50 \\
4.37 \\
4.87 \\
4.94 \\
4.88 \\
4.91 \\
\end{array}$ & $\begin{array}{l}1.00 \\
1.34 \\
2.16 \\
3.60 \\
4.47 \\
4.96 \\
5.02 \\
4.94 \\
4.96 \\
\end{array}$ & $\begin{array}{l}1.33 \\
1.72 \\
2.52 \\
3.94 \\
4.79 \\
5.27 \\
5.30 \\
5.21 \\
5.21 \\
\end{array}$ \\
\hline $\begin{array}{c}\text { Texas } \\
1975 \\
1976 \\
1985 \\
1990 \\
1995 \\
2000 \\
2005 \\
2010 \\
2015\end{array}$ & $\begin{array}{l}0.69 \\
1.07 \\
2.35 \\
3.34 \\
4.19 \\
4.74 \\
4.75 \\
4.67 \\
4.67\end{array}$ & $\begin{array}{l}0.18 \\
0.15 \\
0.40 \\
-- \\
\because \\
\because \\
\because \\
\therefore\end{array}$ & $\begin{array}{l}0.26 \\
0.32 \\
0.36 \\
0.38 \\
0.40 \\
0.43 \\
0.46 \\
0.49 \\
0.52\end{array}$ & $\begin{array}{l}0.62 \\
0.75 \\
0.78 \\
0.80 \\
0.82 \\
0.84 \\
0.87 \\
0.89 \\
0.91\end{array}$ & $\begin{array}{l}0.83 \\
1.03 \\
1.02 \\
1.02 \\
1.01 \\
1.01 \\
1.00 \\
1.00 \\
0.99\end{array}$ & $\begin{array}{c}0.87 \\
1.22 \\
2.75 \\
-\because \\
\because- \\
- \\
\because- \\
-\end{array}$ & $\begin{array}{l}0.95 \\
1.39 \\
2.71 \\
3.72 \\
4.59 \\
5.17 \\
5.21 \\
5.16 \\
5.19\end{array}$ & $\begin{array}{l}1.31 \\
1.82 \\
3.13 \\
4.14 \\
5.01 \\
5.58 \\
5.62 \\
5.56 \\
5.58\end{array}$ & $\begin{array}{l}1.52 \\
2.10 \\
3.37 \\
4.36 \\
5.20 \\
5.75 \\
5.75 \\
5.67 \\
5.66\end{array}$ \\
\hline
\end{tabular}


Table 3-15. Energy Prices in California

\begin{tabular}{|c|c|c|c|c|c|c|c|c|c|}
\hline \multirow{2}{*}{$\begin{array}{l}\text { Use } \\
\text { Sector }\end{array}$} & \multicolumn{9}{|c|}{ Cents per Million Btu } \\
\hline & 1974 & $1 \ni 75$ & 1985 & 1990 & 1995 & 2000 & 2005 & 2010 & 2015 \\
\hline \\
\hline Natural Gas & 128 & 146 & 334 & 404 & 471 & 510 & 507 & 500 & 500 \\
\hline Electricity & 902 & 779 & 1201 & 1289 & 1406 & 1494 & 1553 & 1670 & 1787 \\
\hline & 272 & 284 & 430 & 475 & 525 & 574 & 576 & 579 & 581 \\
\hline \multicolumn{10}{|l|}{ Commercial } \\
\hline Natural Gas & 94 & 121 & 321 & 392 & 460 & 501 & 500 & 496 & 498 \\
\hline Electricity & 809 & 388 & 1172 & 1289 & 1406 & 1494 & 1553 & 1670 & 1787 \\
\hline Light Fuel Oil & 219 & 258 & 403 & 448 & 498 & 547 & 548 & 551 & 553 \\
\hline Heavy Fuel Oil & 183 & 267 & 352 & 393 & 441 & 490 & 492 & 493 & 495 \\
\hline Coal & -- & - & - & - & -- & -- & -- & - & - - \\
\hline \multicolumn{10}{|l|}{ Industrial } \\
\hline Natural Gas & 64 & -03 & 319 & 390 & 459 & 500 & 498 & 494 & 496 \\
\hline Electricity & 527 & 621 & 967. & 1084 & 1231 & 1348 & 1436 & 1582 & 1729 \\
\hline Light Fuel Oil & 197 & 237 & 380 & 425 & 474 & 524 & 526 & 528 & 530 \\
\hline Heavy Fuel Oil & 172 & 198 & 336 & 375 & 422 & 470 & 471 & 473 & 475 \\
\hline Coal & 125 & 134 & 145 & 166 & 185 & 204 & 235 & 275 & 319 \\
\hline \multicolumn{10}{|l|}{ Power Plants } \\
\hline Natural Gas & 59 & 103 & - - & - - & - - & - - & - & -- & -- \\
\hline Light Fuel Oil & 197 & 2.37 & 380 & 425 & 474 & 524 & 526 & 528 & 530 \\
\hline Heavy Fuel Oil & 161 & 250 & 336 & 375 & 422 & 470 & 471 & 473 & 475 \\
\hline Coal & -- & $-\overline{22}$ & $\begin{array}{r}121 \\
39\end{array}$ & $\begin{array}{r}138 \\
45\end{array}$ & $\begin{array}{r}154 \\
54\end{array}$ & $\begin{array}{r}170 \\
66\end{array}$ & $\begin{array}{r}196 \\
82\end{array}$ & $\begin{array}{l}229 \\
101\end{array}$ & $\begin{array}{l}266 \\
126\end{array}$ \\
\hline INu & & & & & & & & & \\
\hline
\end{tabular}


Table 3-16. Energy Prices in Texas

\begin{tabular}{|c|c|c|c|c|c|c|c|c|c|}
\hline \multirow{2}{*}{$\begin{array}{l}\text { Use } \\
\text { Sector }\end{array}$} & \multicolumn{9}{|c|}{ Cents per Million Btu } \\
\hline & 1974 & 1975 & 1985 & 1990 & 1995 & 2000 & 2005 & 2010 & 2015 \\
\hline Residential & 112 & 145 & 322 & 417 & 498 & 550 & 550 & 543 & 542 \\
\hline Electricity & 706 & 800 & 1318 & 1436 & 1494 & 1553 & 1670 & 1729 & 1904 \\
\hline Light Fuel Oil & 250 & 266 & 411 & 456 & 508 & 557 & 559 & 561 & 564 \\
\hline \multicolumn{10}{|l|}{ Commercial } \\
\hline Natural Gas & 83 & 125 & 300 & 396 & 479 & 534 & 538 & 532 & 534 \\
\hline Electricity & 607 & 709 & 1260 & 1406 & 1494 & 1553 & 1670 & 1729 & 1904 \\
\hline Light Fuel Oil & 180 & 239 & 387 & 432 & 484 & 533 & 535 & 538 & 539 \\
\hline Heavy Fuel Oil & 171 & 207 & 358 & 402 & 451 & 500 & 502 & 503 & 505 \\
\hline Coal & -- & - & - & - - & -- & -- & -- & -- & -- \\
\hline \multicolumn{10}{|l|}{ Industrial } \\
\hline Natural Gas & 51 & 91 & 259 & 356 & 439 & 495 & 499 & 494 & 497 \\
\hline Electricity & 340 & 437 & 1026 & 1172 & 1260 & 1348 & 1494 & 1582 & 1787 \\
\hline Light Fuel Oil & 160 & 216 & 365 & 410 & 462 & 511 & 512 & 515 & 517 \\
\hline Heavy Fuel Oil & 160 & 196 & 342 & 383 & 432 & 479 & 481 & 483 & 484 \\
\hline Coal & 53 & 62 & 108 & 119 & 130 & 143 & 169 & 204 & 246 \\
\hline \multicolumn{10}{|l|}{ Power Plants } \\
\hline Natural Gas & 45 & 83 & 263 & -- & -- & -- & -- & $-i$ & $-i$ \\
\hline Light Fuel Oil & 158 & 216 & 373 & 418 & 469 & 519 & 520 & 523 & 525 \\
\hline $\begin{array}{l}\text { Heavy Fuel Oil } \\
\text { Coal }\end{array}$ & $\begin{array}{r}149 \\
17\end{array}$ & $\begin{array}{r}189 \\
24\end{array}$ & $\begin{array}{r}333 \\
90\end{array}$ & $\begin{array}{r}375 \\
99\end{array}$ & $\begin{array}{l}422 \\
108\end{array}$ & $\begin{array}{l}470 \\
119\end{array}$ & $\begin{array}{l}471 \\
141\end{array}$ & $\begin{array}{l}473 \\
170\end{array}$ & $\begin{array}{l}475 \\
205\end{array}$ \\
\hline Nuclear & & - - & 39 & 45 & 54 & 66 & 82 & 101 & 126 \\
\hline
\end{tabular}


Table: 3-17. Energy Prices in New Mexico

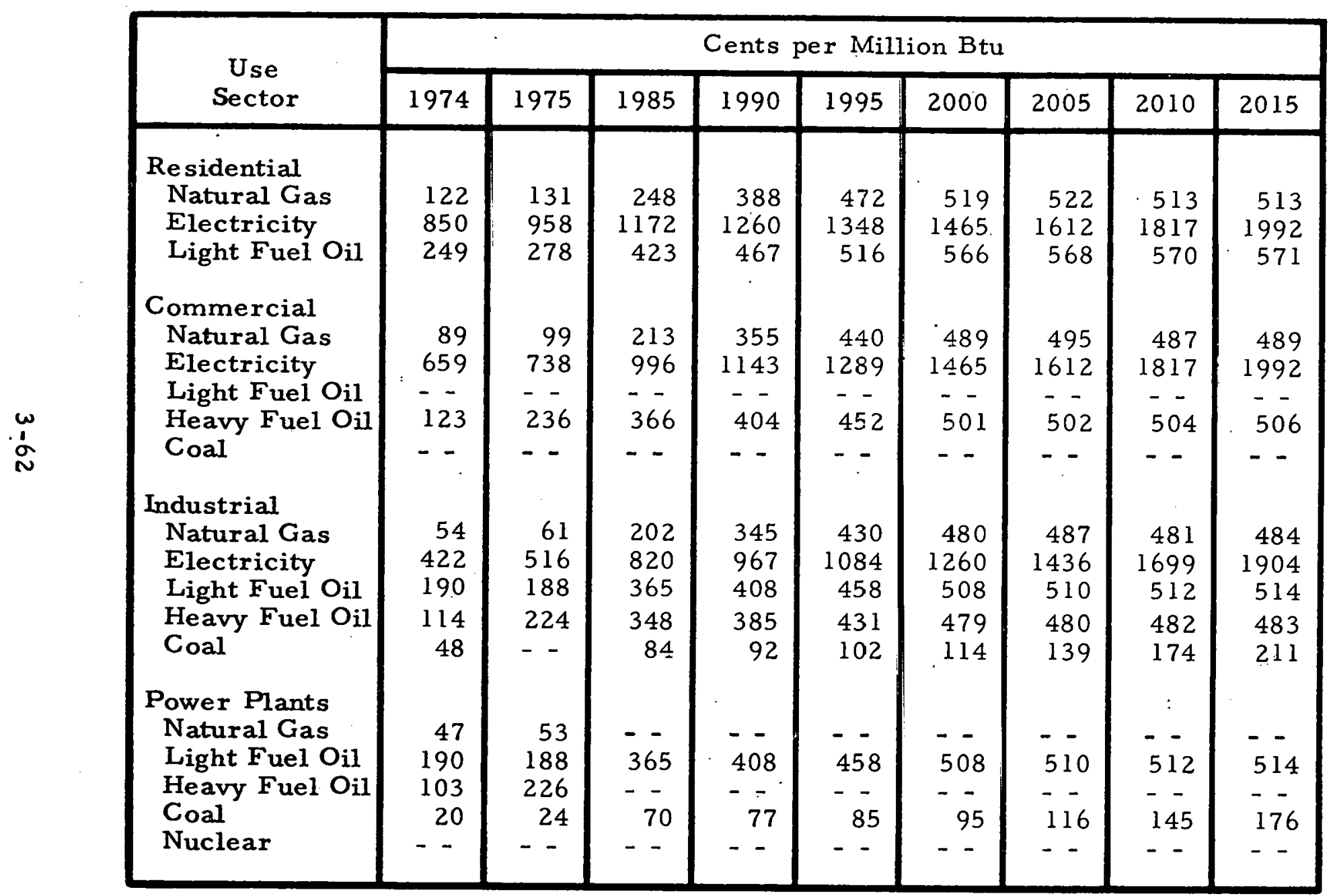


Table 3-18. Energy Prices in Arizona

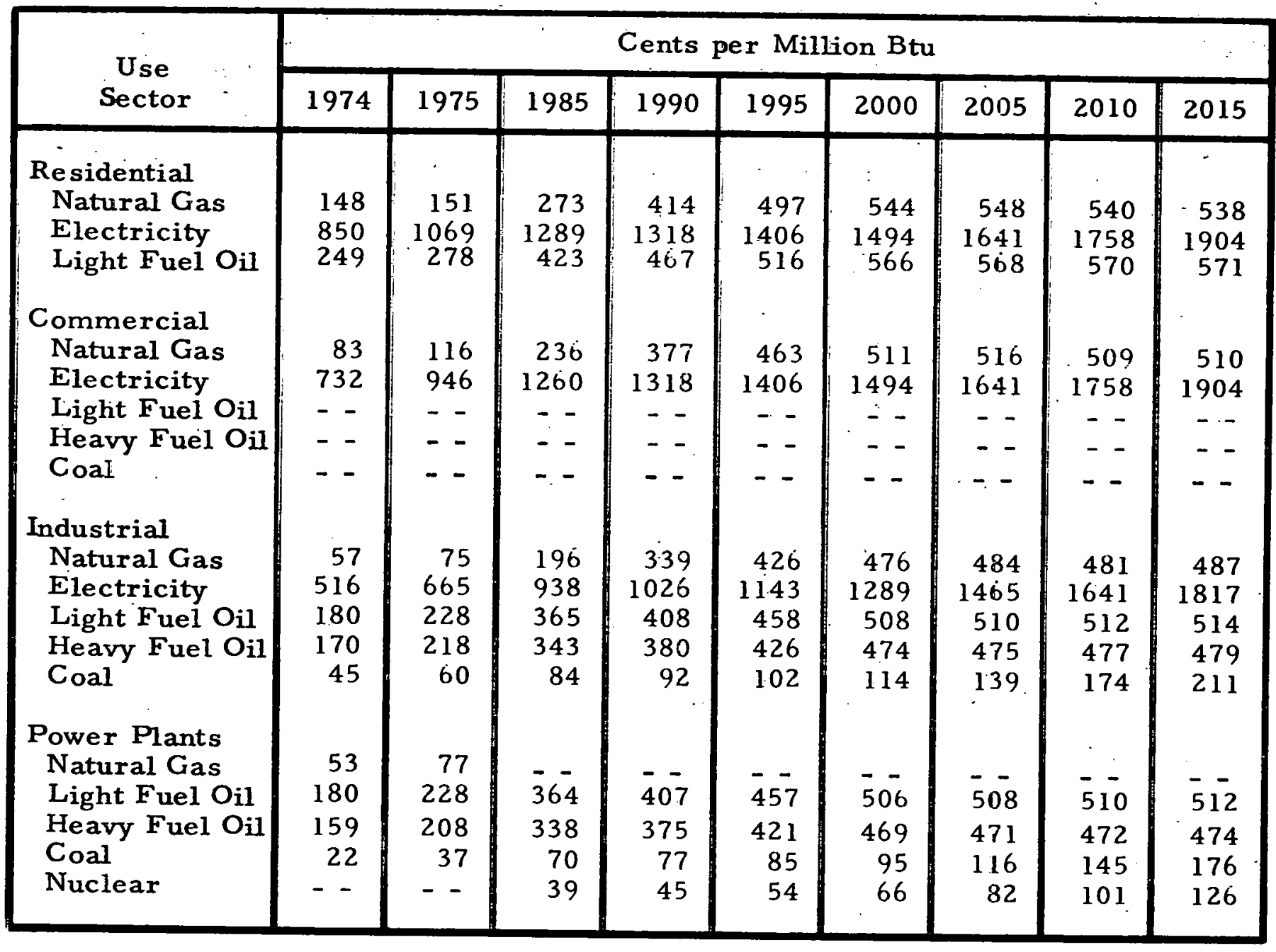


Table 3-19. Energy Prices in Nevada

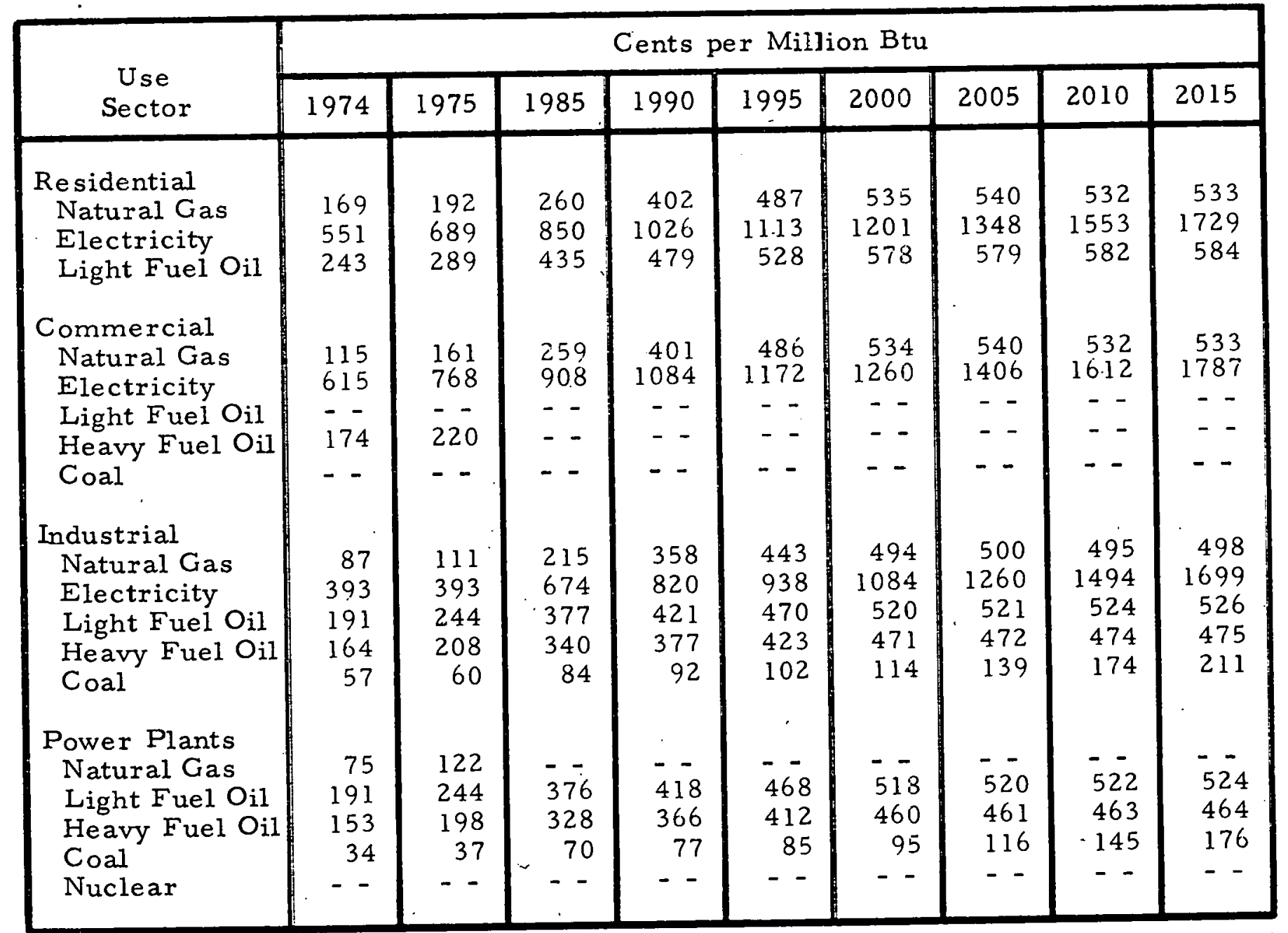


industrial äpplications were used instead. This assumption is consistent with the historical costing relationship between natural gas costs for power plants and industrial usage.

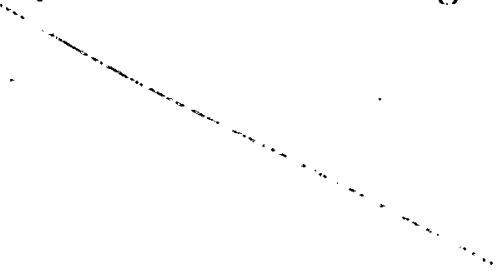




\section{SMALL POWER SYSTEMS BREAKEVEN COST ANALYSIS}

\section{$4.1 \quad$ INTRODUCTION}

The overall goal of the Small Power Systems Study is to determine conditions under which small solar thermal power systems can produce electrical, power in a cost-effective manner when introduced into the U.S. power production inventory. Although utility systems would be expected to be the largest user of small solar thermal power systems, other potential users could include industrial power plants, the Department of Defense, and remote applications such as mining and lumbering. The approach followed in this study has been to collect sufficient data on small power systems in the U.S. to be able to characterize both the different types of small generating units and the systems which contain them. This characterization is in sufficient detail to analyze the potential market for small solar thermal power systems and to determine the conditions under which the small solar thermal power systems could penetrate this market. The analyses to be described in this section are confined to utility system applications. The industrial applications will be examined in the follow-on contract using data from the Federal Energy Regulatory Commission collected under the current contract. M1litary utility systems and remote applications will be discussed briefly in sections 5 and 7 , but will not be analyzed because the avallable data on these two applications indicate that they do not represent generic classes of applications.

A decision was made to test the analytical procedures to be used in the cost analyses on a limited number of cases using the best data available in mid-April 1978 and, based on the value of the fossil fuel saved as a result of 1nstalling a solar thermal power plant, establish an upper limit for the cost of the solar plant if 1 t. is to be 
cost-competitive compared to the fossil-fueled power plant. The cases selected for the initial set of analyses were deliberately made as favorable as possible for the solar thermal power systems in order to determine whether solar power systems could penetrate the utility market as early as 1985 and, if not, what conditions would be required to permit penetration. Thus, the initial set of analyses examines only the five southwestern "sun belt" states and uses a heliostat cost of $\$ 70 / \mathrm{m}^{2}$, which is equal to the DOE goal for advanced heliostats. Although it is unlikely that heliostat costs (or equivalent distributed collector costs) as low as those used in this analysis will be achievable in 1985 without Government intervention, the use of low costs for solar systems serves to identify the magnitude of the economic barriers which must be overcome if solar thermal power systems are to penetrate the utility market. It was also hoped that the initial set of analyses, in addition to checking out the analytical procedures, would identify promising avenues for future analyses.

The ERDA/EPRI cost methodology (Reference 12) was selected for the initial set of cost analyses of small solar thermal power systems and oil- and gas-fired steam-electric plants and diesel generators. This selection was made for two reasons: (1) the analyses would be relatable to analyses made on other solar thermal power system studies by other contractors using the same methodology and (2) other Aerospace Corporation financial models are too sophisticated to justify their use on the initial set of cost analyses. The fuel savings achievable through the displacement of a conventional small power system by a solar thermal power system were calculated separately, rather trian with the ERDA/EPRI methodology, because the methodology uses a single value with a fixed escalation rate for the fuel cost while the Sherman H. Clark cost forecasts are for a series of five-year intervals through 2015 . The shapes of the fuel cost curves covering the 30-year period of analysis are different when calculated with a constant escalation rate using the 
ERDA/EPRI methodology and when curves are fitted to the Sherman H. Clark forecasts. The independent calculation. of the fuel savings using the Sherman H. Clark data made it possible to include those data in the breakeven cost analysis.

The small solar thermal power systems were examined for two operational modes, repowering and replacement. In the repowering mode, the solar power system provides thermal energy during periods of acceptable insolation to the steam turbine of a conventional steamelectric plant, as well as to a thermal storage system. (In the initial set of repowering analyses, the solar thermal power plant was sized for "zero" storage to minimize capital costs.) Whenever the insolation is too low, the steam-electric plant either generates its own power by burning fossil fuel (or operates off the thermal energy stored by the solar power system). In the repowering mode, the solar power system costs include the solar collectors (heliostats), receivers, controls, and associated piping and valves. Figure $4-1$ is a conceptual representation of a repowered steam-electric plant. In the replacement mode, the power conversion equipment, i.e., turbine-generators, must also be purchased for the solar thermal power system. (Again, in the initial set of replacement analyses, no provision was made for thermal storage.) Repowering would be the preferred operational mode for a steam-electric plant which already has the power conversion equipment. Replacement would be the requi.red operational mode for a diesel generator, which does not use turbine generators. Whenever the insolation is too low for operation of the solar thermal power system, the diesel generator would be turned on to produce electrical power.

4.2 CASES ANALYZED

As indicated in Section 4.1, 1985 was selected as the startup date for small solar thermal power plants in the initial 


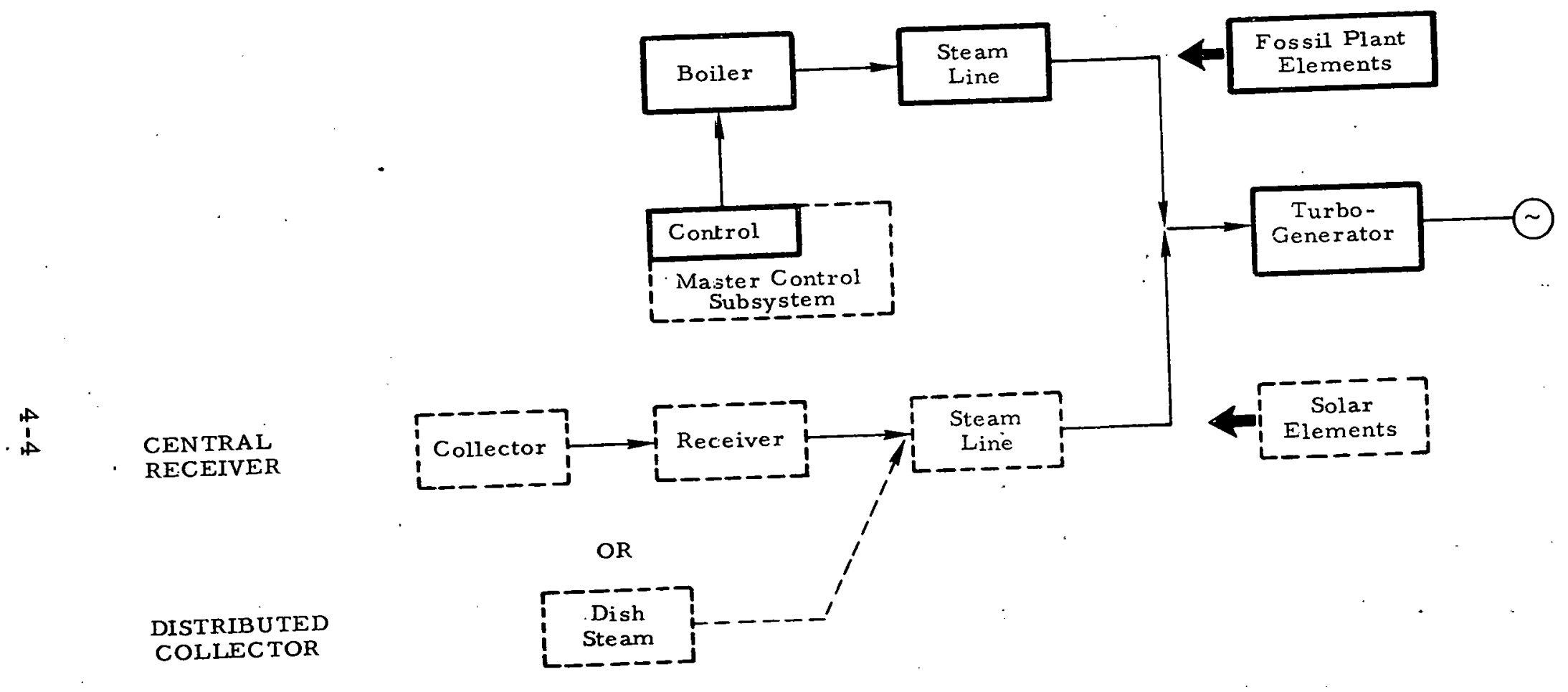

Figure 4-1. Solar Repowering Concept 
breakeven cost analysis in order to determine the early market potential for such systems. The effect of later startup dates for small solar thermal power systems will be examined in the follow-on study; however, Nevada was brlefly analyzed for a 2000 startup date using $1 \mathrm{MW}$ and $10 \mathrm{MW}$ steam plants and diesel generators to determine $1 f^{\prime}$ the higher fuel prloes would make small solar thermal plants cost-effective in comparison to conventional plants. Table 4-1 l1sts the variables used in the inftial breakeven cost analysis and the values or cases considered.

Table 4-1. Variables Used in Inttial Breakeven Cost Analysis

\begin{tabular}{|l|l|}
\hline \multicolumn{1}{|c|}{ Variable } & \multicolumn{1}{|c|}{ Value/Case } \\
\hline Location & Arizona, California, Nevada, New Mexico, Texas \\
Type of Plant & Solar Thermal, Steam-Electric, Diesel \\
Operational Mode & Repowering, Replacement \\
Plant Size (MWe $)$ & 1, 10 \\
Type of Ownership & Municipal, Investor -Owned \\
Fossil Fuel & No.2 Fuel Oil, Natural Gas \\
Inflation (Percent) & $0,3.5$ \\
Heliostat Cost $\left(\$ / \mathrm{m}^{2}\right)$ & 70 (baseline), 210,140;50 \\
\hline
\end{tabular}

The five southwestern "sun belt" states were chosen for the initial set of analyses to make the results as favorable as possible for small solar thermal power systems. A city was selected in each of the five states for which solar insolation data were avallable. If more than one city with such data existed for any state, the city with the highest insolation value was selected. The following clties were used in the analysis: 


\begin{tabular}{|l|l|c|}
\hline \multicolumn{1}{|c|}{ State } & \multicolumn{1}{|c|}{ City } & $\begin{array}{c}\text { Average Daily } \\
\text { Direct Insolation } \\
\text { (kWh/m2/day) }\end{array}$ \\
\hline Arizona & Phoenix & 6.92 \\
California & Inyokern & 7.85 \\
Nevada & Ely & 6.63 \\
New Mexico & Albuquerque & 7.13 \\
Texas & El Paso & 7.26 \\
\hline
\end{tabular}

The breakeven cost analysis compares a small solar thermal power system operating with zero thermal storage capacity in either a repowering mode with a fossil-fueled steam-electric plant or in a replacement mode for a steam-electric plant or a diesel generator. Specific cost and performance (heat rate) data for small solar thermal power systems of the central receiver-type, for fossil-fueled steam-electric plants, and for diesel generators with $1 \mathrm{MW}$ and 10 MW generating capacities were taken from the parametric data in Sections 3.2 and 3.3. I'he central receiver data for these two plant sizes are given in Table 4-2, the steam-electric plants are shown in Table 4-3, and the diesel data are contained in Table, 4-4. Levelized operations and maintenance (O\&M) costs for each of these plants were calculated by developing a 30-year cost stream for each of the plants, based on an annual expenditure of one percent of the capital cost of that plant, and then discounting the stream back to a present value in 1977 dollars. The O\&M costs for each type of plant and solar thermal power system operating mode (1.e., repowering or replacement) are shown in Table 4-5. 
Table 4-2. Central Receiver Coşt Data for Breakeven Analysis

\begin{tabular}{|c|c|c|}
\hline $\begin{array}{c}\text { Operational, } \\
\text { Mode }\end{array}$ & \multicolumn{2}{|c|}{ Cost in Dollars/Kilowatt } \\
\hline & $1 \mathrm{MW}$ & $10 \mathrm{MW}$ \\
\hline Repowering & 2734 & 1285 \\
Replacement & 5032 & 2230 \\
\hline
\end{tabular}

Table 4-3. Steam-Electric Cost and Performance Data for Breakeven Analysis

\begin{tabular}{|c|c|c|}
\hline$\therefore \quad$ Parameter & $1 \mathrm{MW}_{\mathrm{e}}$ & $10 \mathrm{MW}$ e \\
\hline $\operatorname{Cost}\left(\$ / k W_{e}\right)$ & 2600 & 1132 \\
\hline Heat Rate (Btu/kWh) & 21000 & 14000 \\
\hline
\end{tabular}

Table 4-4. Diesel Generator Cost and Performance Data for Breakeven Analysis

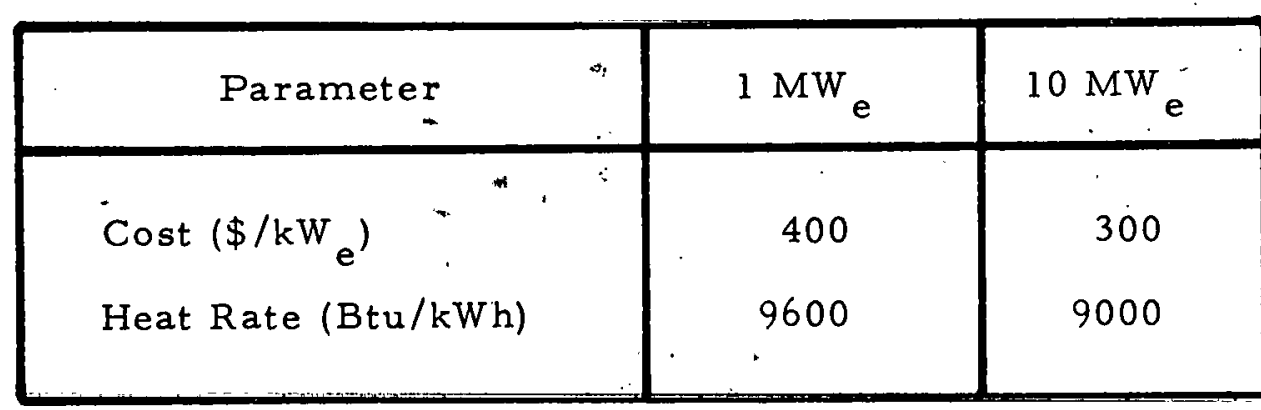

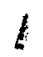

$4-7$ 
Table 4-5. Operations and Maintenance Cost for Breakeven Analysis .

\begin{tabular}{|c|c|c|}
\hline Plant & \multicolumn{2}{|c|}{ Cost in Mills/Kilowatt-Hour } \\
\cline { 2 - 3 } & $1 \mathrm{MW}$ & $10 \mathrm{MW}_{\mathrm{e}}$ \\
\hline Solar & & $:$ \\
Repowering & 13 & 6 \\
Replacement & 23 & 10 \\
Steam-Electric & 12 & 5 \\
Diesel Generator & 2 & 1 \\
\hline
\end{tabular}

Two sizes were selected for the small power plants to examine the effect of plant size and economy of scale on the results. The lower value of $1 \mathrm{MW}$ might represent a modular size for a distributed collector-type of solar thermal power plant. The $10 \mathrm{MW}_{e}$ plant is the upper limit speolfied for the Small Power Systems Study. A plant capaolty faotor of 0.25 was used for all of the analyses but was reduced by the ratio of the state insolation value-to-the California insolation value for all states exoept California. The value of 0.25 was selected on the basis of prior work at The Aerospace Corporation on the repowering of larger generating units. It is not optimum, but is close to being optimum. The cost data for $1 \mathrm{MW}$ power plants of all types except diesel generators should be used with a great deal of caution, compared to the data for $10 \mathrm{MW}$ plants, because these data have been extrapolated from data for plants at least an order of magnitude larger in size into a size range where the effect of economy of scale is belleved to be extremely strong. The diesel generator data, on the other hand, are based on the cost and performance of commerclally avallable models of a specific brand of diesel equipment. The particular manufacturer was chosen because its diesels are currently in widespread 
use in small utility systems and because its diesels appear to have captured a sizeable segment of the market for diesel generators in the utility sector.

Municipal and investor ownership were used in the analysis to determine the effect of cost of capital on the results of the analysis. Electrical cooperatives were not considered in the analysis since it was felt that cooperatives would resemble municipal utility systems in their financlal behavior. The financial faotors used in the analysis, with and without a 3.5 percent inflation factor, are listed in Table 4-6. The table also indicates the symbols associated with the various financial factors, based on the ERDA/EPRI cost methodology (Reference 12).

Both natural gas and No. 2 fuel oil were examined as possible fuels for fossil-fueled steam-electric plants and diesel generators in order to determine the sensitivity of the results of the analysis to fuel costs. Sherman H. Clark Associates' price forecasts for these fuels (Reference 7) were used in the analysis. Since natural gas was postulated by Sherman H. Clark Associates to be unavailable in the five states for power plant use in the time period of interest, they did not forecast gas prices in these states for power plant use. As a result, it was necessary to substitute gas prices for industrial use on the basis of the generally closer historical correlation between these two use. sectors compared to commercial or residential gas prices. Table 4-7 lists the forecast natural gas and No. 2 fuel oil prices for each of the f1ve southwestern states for the 1985-2015 time period in constant 1977 dollars per million Btu.

The effect of inflation was tested by using a "zero" inflation rate and a 3.5 percent rate of inflation. Although not shown 
Table 4-6. Financial Factors Used in Breakeven Cost Analysis

\begin{tabular}{|c|c|c|c|c|}
\hline & Symbol & Narne & $\begin{array}{c}\text { Municipally- } \\
\text { Owned }\end{array}$ & $\begin{array}{l}\text { Investor - } \\
\text { Owned }\end{array}$ \\
\hline & $\begin{array}{l}\boldsymbol{\beta}_{1} \\
\boldsymbol{\beta}_{2} \\
\tau \\
\mathrm{D} / \mathrm{V} \\
\mathrm{C} / \mathrm{V} \\
\mathrm{P} / \mathrm{V} \\
\mathrm{k}_{\mathrm{d}} \\
\mathrm{k}_{\mathrm{c}} \\
\propto \\
\mathrm{DPF}_{\mathrm{m}}\end{array}$ & $\begin{array}{l}\text { Utility Syster Data } \\
\text { System Operating Lifetime } \\
\text { Annual "Other Taxes" as Fraction of CI } * \\
\text { Annual Insurance Premiums as a Fraction of CI } \\
\text { Income Tax Rate } \\
\text { Ratio of Debt-to-Total Capitalization } \\
\text { Ratio of Common Stock-to-Total Capitalization } \\
\text { Ratio of Preferred Stock-to-Total Capitalization } \\
\text { Debt Interest Rate } \\
\text { Annual Rate of Return on Common Stock } \\
\text { Investment Tax Credit } \\
\text { Depreciation Method } \\
\qquad \text { General Economic Conditions } \\
\text { Rate of General Inflation } \\
\text { Escalation Plus Inflation Rate for Capital Costs } * * * * \\
\text { Escalation Plus Inflation Rase for Operating Costs } \\
\text { Escalation Plus Inflation Rate for Maintenance Costs } \\
\text { Base Year for Constant Dollars }\end{array}$ & $\begin{array}{l}30 \\
0.02 \\
0.0025 \\
0.0 \\
1.0 \\
0.0 \\
0.0 \\
0.025^{* * *} \\
0.0 \\
0.0 \\
\text { Straight } \\
\text { Line } \\
\\
0.0^{* * * *} \\
0.0^{* * *} \\
0.0^{* *} \\
0.0^{* * *} \\
1977\end{array}$ & $\begin{array}{l}30 \\
0.02 \\
0.0025 \\
0.50 \\
0.55 \\
0.45 \\
0.0 \\
0.035^{* * *} \\
0.07^{* *} \\
0.10 \\
\text { Sum of Years } \\
\text { Digits } \\
0.0^{* * *} \\
0.0 * * \\
0.0^{* * *} \\
0.0^{* *} \\
1977\end{array}$ \\
\hline
\end{tabular}

$\because \mathrm{CI}_{\mathrm{pv}}$ is present value of capital investment.

** Add 0.035 for inflation.

***: Escalation is assumed to be zerc for each of these cases. Therefore, the sum of the escalation and inflation rates is identical to the inflation rate. 
Table 4-7. Forecast Natural Gas and No. 2 Fuel 0 il Prices for $1985-2015$

\begin{tabular}{|c|c|c|c|c|c|c|c|c|c|c|}
\hline \multirow{4}{*}{ Year } & \multicolumn{8}{|c|}{ Price in 1977 Dollars per Million Btu } \\
\cline { 2 - 11 } & Arizona & California & \multicolumn{2}{c|}{ Nevada } & \multicolumn{2}{c|}{ New Mexico } & \multicolumn{2}{c|}{ Texas } \\
\cline { 2 - 11 } & Gas & Oil & Gas & Oil & Gas & Oil & Gas & Oil & Gas & Oil \\
\hline 1985 & 1.96 & 3.64 & 3.19 & 3.80 & 2.15 & 3.76 & 2.02 & 3.65 & 2.59 & 3.73 \\
1990 & 3.39 & 4.07 & 3.90 & 4.25 & 3.58 & 4.18 & 3.45 & 4.08 & 3.56 & 4.18 \\
1995 & 4.26 & 4.57 & 1.59 & 1.71 & 1.13 & 1.68 & 4.30 & 4.50 & 4.39 & 4.69 \\
2000 & 4.76 & 5.06 & 5.00 & 5.24 & 4.94 & 5.18 & 4.80 & 5.08 & 4.95 & 5.19 \\
2005 & 4.84 & 5.08 & 4.98 & 5.26 & 5.00 & 5.20 & 4.87 & 5.10 & 4.99 & 5.20 \\
2010 & 4.81 & 5.10 & 4.94 & 5.28 & 4.95 & 5.22 & 4.81 & 5.12 & 4.94 & 5.23 \\
2015 & 4.87 & 5.12 & 4.96 & 5.30 & 4.98 & 5.24 & 4.84 & 5.14 & 4.97 & 5.25 \\
& & & & & & & & & & \\
\hline
\end{tabular}

in any of the reported cases, the effect of a 7 percent inflation rate was calculated for four cases. Figure 4-2 shows the departure from linearity $(\sim 0.06)$ of the 7 percent rate, based on a 30 -year annualized cost history. The figure permits the user to select any inflation rate up to 7 percent and to estimate the effect of that rate on lifecycle costs for his system.

It was indicated in Section 4.1 that the values for the variables in the initial set of breakeven cost analyses were deliberately selected to bias the results of the initial analyses in favor of small solar thermal power systems, while still retaining a sound engineering basis for the assumptions made. Thus, in the case of the heliostat costs for a central receiver-type of solar thermal power system, a cost of $\$ 70 / \mathrm{m}^{2}$ was used since this value represents a stated DOE/DST goal for advanced heliostats. While it is unlikely that this goal would be met in 


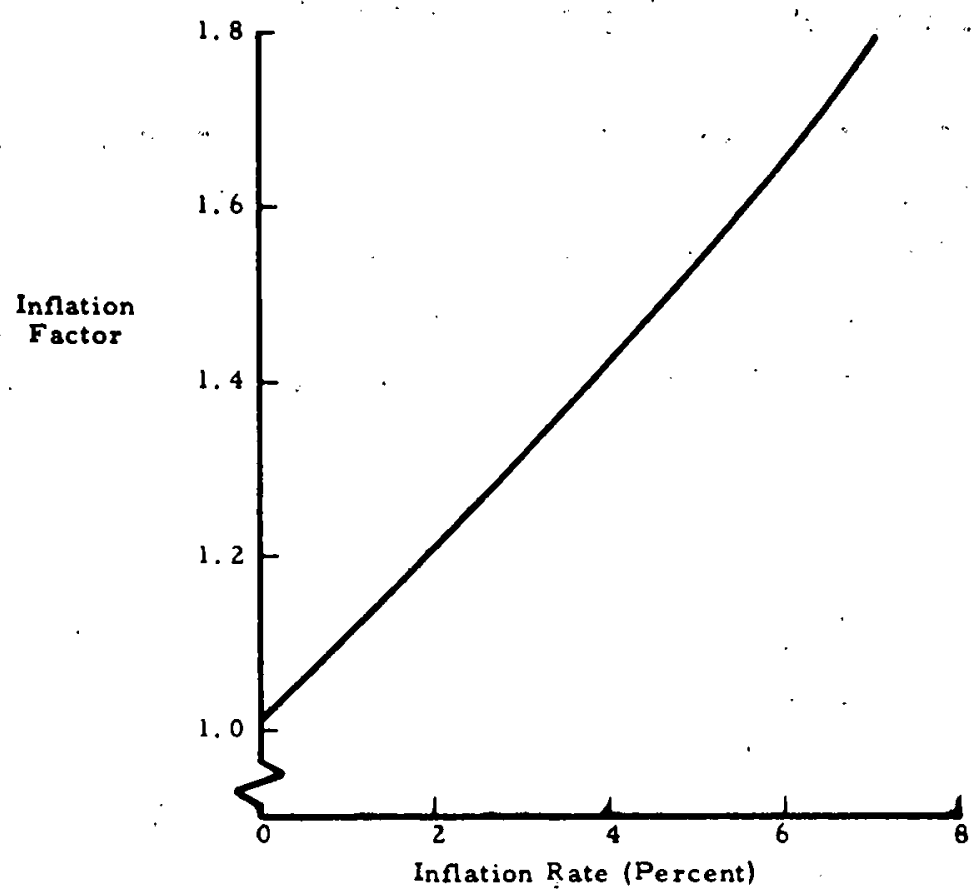

Figure 4-2. Effect of Inflation Rate on 30-Year Costs

1985. without Government intervention of some type, and then only for a limited number. of systems, it is, nevertheless, a stated value. The sensitivity of the results of the breakeven cost analysis to a lower or to higher: values of the heliostat cost was assessed by using a value of $\$ 50 / \mathrm{m}^{2}$ for the former case and values of $\$ 140 / \mathrm{m}^{2}$ and $\$ 210 / \mathrm{m}^{2}$ to reflect a doubling or tripling of hellostat costs, respectively.

It was intended that the breakeven cost analysis be applicable to solar thermal power systems of any type, i.e., either distributed collector or central recelver. However, since the data base at The Aerospace Corporation for solar thermal power systems consists primarily of information. on the central recelver-type of system, it was necessary to use the available data for that type of system. On the other hand, the effect of variations in heliostat costs can be viewed in a broader context as being equivalent to similar variations in the overall costs of a distributed collector-type of small solar thermal power system. 
Th1s seotion describes the bas10; approach used in accomplishing the breakeven cost analysis. Section 4.3 .1 disousses the applioation of the ERDA/EPRI cost methodology to the oosts of the solar thermal and fossil-fueled power plants, exolusive of the fossil fuel costs themselves. The caloulation of the fuel savings 18 disoussed in Seotion 4.3 .2 .

4.3.1 Cost Analysis by Means of the ERDA/EPRI Methodology

The steps used in calculating the busbar energy cost from solar and fossil-fueled power plants, using the ERDA/EPRI cost methodology, are desoribed below. Ali calculations have been oarried out for one kllowatt of output to simplify the manipulation of the results, whlch are expressed in 1977 dollars in terms of m1lls per k1lowatt-hour. The finanolal inputs used in these oaloulations were shown previousiy in Table 4-6. Flgure 4-3 (whioh is reproduoed from Flgure 2 of Referenoe 12) presents the flow of caloulations associated with this methodology.

The disoussion of the use of the methodology follows the ' same sequence used in Reference 12; 1.e., 1t treats the individual cost. elements and then ties all the elements together to derive the levelized busbar energy cost. The following cost elements are caloulated in this procedure: .

1. Cost of Capital to a Ut1lity (k)

2. Capital. Recovery Factor (CRF)

3. Annualized Fixed Charge Rate (FCR) .

4.- Present Value of Capital Investment ( $\mathrm{CI}_{\mathrm{pv}}$ )

5. Present Value óf Fuel Cost (FL

6. Present Value of other Operations and Maintenance Costs $\left(X_{p v^{\prime}}\right)$ 


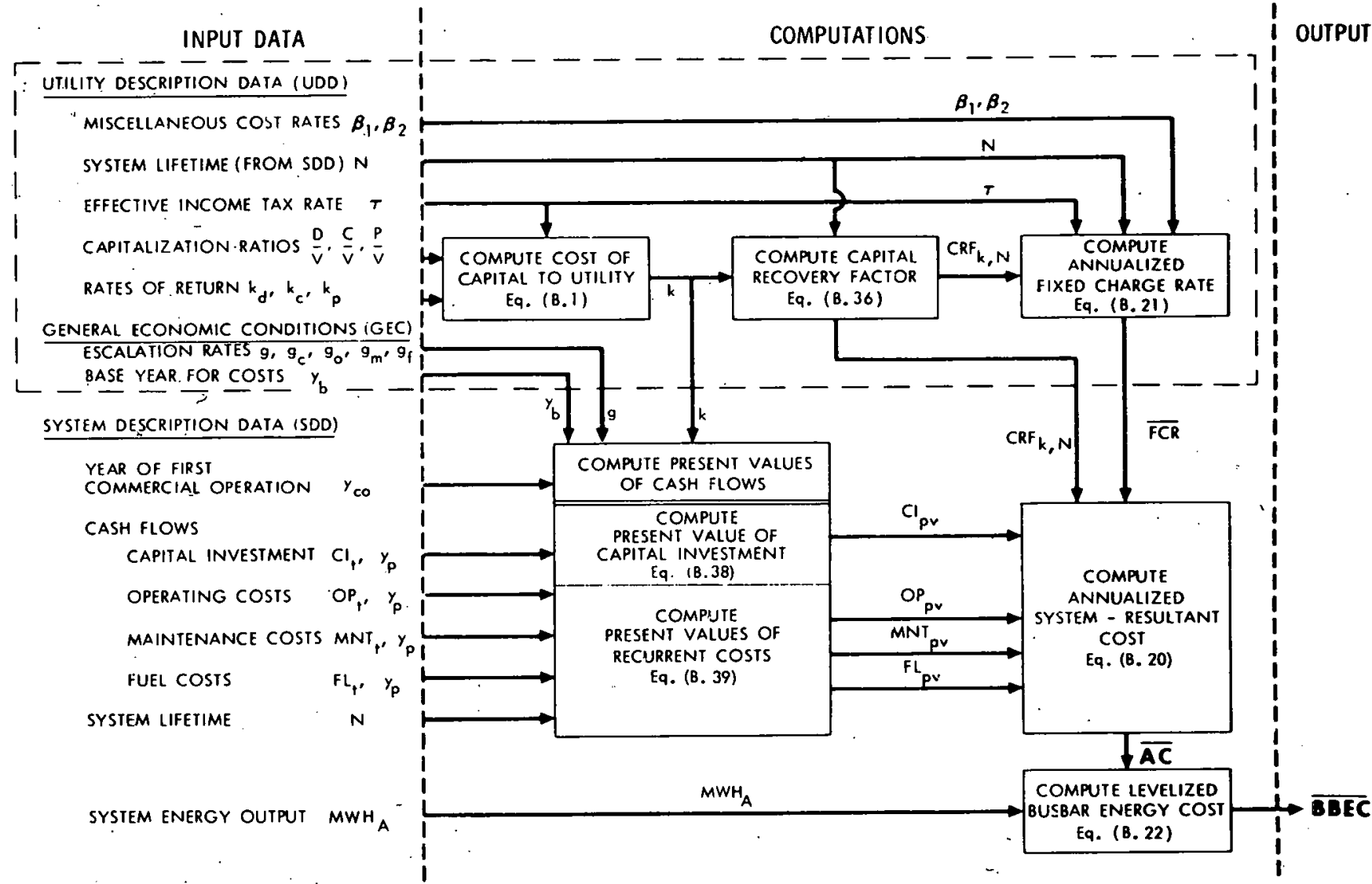

Figure 4-3. ERDA/EPRI Cost Methodology Flow 


\section{Annualized System Cost (AC)}

8. Levelized System Cost per kilowatt-hour (LC)

\subsubsection{Cost of Capital}

The cost of capital, $k$, is the interest rate which must be paid by a utility to raise capital. It was calculated using the following equation, which is identical to equation B. 1 of Reference 12.

$$
k=(1-\tau) k_{d} \cdot \frac{D}{V}+k_{c} \cdot \frac{C}{V}+k_{p} \cdot \frac{P}{V}
$$

where

$$
\begin{aligned}
& \tau=\text { income tax rate } \\
& k_{d}=\text { annual rate of return on debt } \\
& k_{c}=\text { annual rate of return on common stock } \\
& k_{p}=\text { annual rate of return on preferred stock } \\
& D / V=\text { ratio of debt-to-total capitalization } \\
& C / V=\text { ratio of common stock-to-total capitalization } \\
& P / V \quad=\text { ratio of preferred stock-to-total capitalization }
\end{aligned}
$$

\subsubsection{Capital Recovery Factor}

The capital recovery factor, CRF, is the uniform annual payment, expressed as a fraction of the original principal, required to fully amortize a loan over a specified period of time. It depends only upon the interest rate and the amortization period and is expressed as:

$$
C R F=\frac{k}{1-(1+k)^{-N}}
$$

\footnotetext{
where $\quad k=$ cost of capital

$\mathrm{N} \quad=$ number of years in amortization period (30 years)
} 
Equation 4-2 is 1dentical to equation B.36 of Reference 12 .

\subsubsection{Annualized Fixed Charge Rate}

The annuajized fixed charge rate, FCR, is the factor by which the present value of capital investment $\left(\mathrm{CI}_{\mathrm{pv}}\right)$ must be multiplied to obtain the contribution of the captal investment to the annualized cost. The rate was calculated by the following equation, which is identical to equation E.11 of Reference 12.

$$
\mathrm{FCR}=\mathrm{CRF}\left[\frac{1-\tau(\mathrm{DPF})-\alpha}{1-\tau}\right]+\beta_{1}+\beta_{2}
$$

$$
\text { where } \begin{aligned}
\text { CRF } & =\text { capital recovery factor } \\
\tau & =\text { income tax rate } \\
\alpha & =\text { investment tax credit } \\
\beta_{1} & =\text { property tax factor } \\
\beta_{2} & =\text { insurance factor } \\
\text { DPF } & =\text { depreciation factor }
\end{aligned}
$$

4.3.1.4 Present Value of Capital Investment

The present value of capital investment expenditures summarizes the total capital investment of a system as a single value by discounting all expenditures back to a base year (1977 for the breakeven cost analysis calculations). The equation for calculating the present value of the investment, which was taken from equation $B .38$ of Reference 12 , is

$$
C I_{p v}=\left(1+g_{c}\right)^{p} \sum_{t}\left[C I_{t}\left(\frac{1+g_{c}}{1+k}\right)^{j}\right]
$$

where

$$
\begin{aligned}
& B_{c}=\text { escalation plus inflation rate for construction } \\
& p=y_{c o}-y_{p}
\end{aligned}
$$




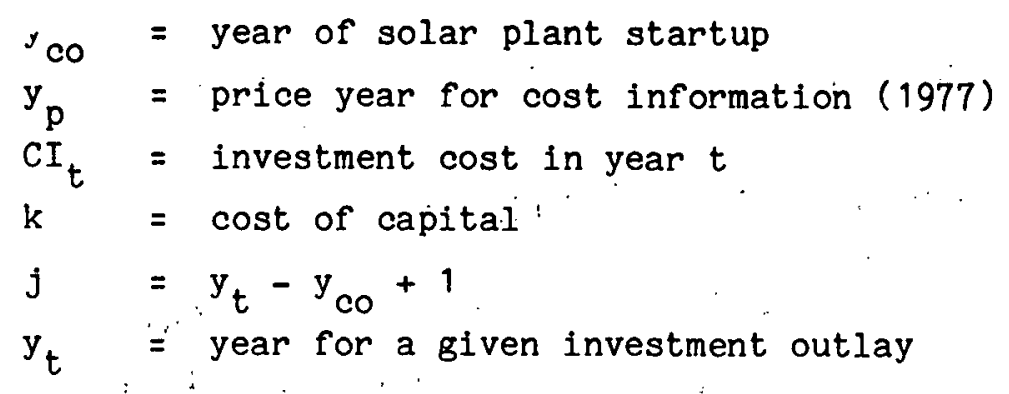

To simplify the breakeven cost analysis, it was assumed that all construction occurred in the year prior to the start of operation, i.e., 1984 for a plant startup in 1985.

\section{3:1.5 Present Value of Fuel Cost}

The present value of: the fuel cost, $\mathrm{FL}_{\mathrm{pv}}$; was calculated from the Sherman H. Clark Associates fuel price forecasts (Reference 7), assuming a uniform change of price within the five-year intervals used for the price forecasts. The external calculation of the present value of the fuel prices is described in Section 4.3 .2 (equation 4-7) and requires the price projections for gas and oil, cost of capital for municipal and investor-owned utility systems, and the inflation rate.

\subsubsection{Present Value of Other Operations and Maintenance Costs}

The present value of the operations and maintenance (O\&M) costs for a utility system, exclusive of the fuel costs, was calculated by means of the following equation, which is the same as equation B. 39 of Reference 12 .

$$
x_{p v}=\left(1+g_{x}\right)^{p} x_{0}\left(\frac{1+g_{x}}{k-g_{x}}\right)\left[1-\left(\frac{1+g_{x}}{1+k}\right)^{N}\right]
$$

where

$$
\mathrm{s}_{\mathrm{x}}=\begin{aligned}
& \text { escalation (plus inflation) rate applicable to the } \\
& \text { operations and maintenance cost }
\end{aligned}
$$




$$
\begin{aligned}
& \mathrm{p}=\mathrm{y}_{\mathrm{co}}-\mathrm{y}_{\mathrm{p}} \text { (an integer constant) } \\
& x_{0}=0 \& M \text { cost in year of plant startup, expressed in } \\
& k=\text { cost of capital } \\
& \mathrm{N} \quad=\text { system lifetime }
\end{aligned}
$$

\subsubsection{Annualized System Cost}

The annualized system cost is the sum of the cost elements described previously in this section converted to their present values and discounted back to 1977 as the base year. Costs can be levelized, rather than annualized as in equation $B .20$ of Reference 12 , if they are expressed relative to a kilowatt-hour of energy. The equation for calculating the annualized system cost is:

$$
A C=(1+g)^{-d}\left[\left(F C R \cdot C I_{p v}\right)+C R F\left(X_{p v}+F L_{p v}\right)\right]
$$

where $\mathrm{g}=$ the general rate of inflation

$\mathrm{d}=\mathrm{y}_{\mathrm{co}}-\mathrm{y}_{\mathrm{b}}$

$y_{b} \quad=$ base year (1977)

\subsubsection{Levelized System Cost}

The annualized cost can be converted to the levelized cost, LC, by simply dividing the annualized cost by the number of kilowatt-hours of energy produced by the power plant annually. In the breakeven analysis, a baseline plant capacity factor of 0.25 was used for California, resulting in 2190 hours of operation per year. Thus, in California, the conversion to a levelized cost would require division by $2.19 \times 10^{6}$ or $2.19 \times 10^{7}$, respectively, for a $1 \mathrm{MW}_{e}$ or a $10 \mathrm{MW}_{\mathrm{e}}$ plant. The conversion of aniualized cost to levelized cost in the other four "sun belt" states merely requires a downward adjustment of the 
number of operational hours per year, e.g., 2023.6 hours for Texas or 1927.2 hours for Arizona. The levelized costs for both solar thermal and conventional power plants are based on the plant capacity factor used in the specific state being analyzed.

\subsubsection{Sample Calculation}

The calculation of costs for a $10 \mathrm{MW}_{e}$, municipally-owned, solar thermal power plant operating in the replacement mode in California in the absence of inflation is described in this section to illustrate the application of the ERDA/EPRI methodology. The cost of a $10 \mathrm{MW}_{\mathrm{e}}$ oil-fired, steam-electric plant operating under the same conditions would be computed in an analogous manner, but would require the addition of the fuel costs. The procedure to be used in calculating the fuel costs (savings) is described in Section 4.3.2. Financial factors required for the computation are given in Table 4-6 (see p. 4-10).

The cost of capital for a municipal power plant is given by a simplified version of equation $4-1$ because a municipal utility pays no income tax and has no stockholders. The resulting equation is:

$$
\begin{aligned}
k & =k_{d}(D / V) \\
& =(0.025)(1) \\
& =(0.025)
\end{aligned}
$$

The capital recovery factor for a plant with a 30-year life is:

$$
\begin{aligned}
\mathrm{CRF} & =\frac{k}{1-(1+k)^{-N}} \\
& =\frac{0.025}{1-(1.025)^{-30}}
\end{aligned}
$$




$$
=\underline{0.0478}
$$

The annualized fixed charge rate for a municipal power plant, which pays no income tax and has no depreciation for tax purposes, is given by the following simple equation derived from equation 4-3.

$$
\begin{aligned}
\mathrm{FCR} & =\mathrm{CRF}+\beta_{1}+\beta_{2} \\
& =0.0478+0.02+0.0025 \\
& =\underline{0.0703}
\end{aligned}
$$

The present value of a $10 \mathrm{MW}$ solar thermal power plant operating in the replacement mode in the absence of inflation simplifies to:

$$
\begin{aligned}
C I_{p v} & =C I_{t} \\
& =\$ 22.3 \times 10^{6},
\end{aligned}
$$

which is the cost of the solar thermàl pilant given às àn inpuit. tó the calculation in Table 4-2.

The present value of the operating and maintenance (O\&M) cost for the solar thermal power plant was assumed to be based on an annual expenditure rate equal to one percent of the investment cost of the plant, i.e., $\$ 2.23 \times 10^{5}$. In the absence of inflation, equation $4-5$ reduces to:

$$
\begin{aligned}
x_{p v} & =x_{0} \cdot \frac{1}{k}\left[1-\left(\frac{1}{1+k}\right)^{N}\right] \\
& =\frac{2.23 \times 10^{5}}{0.025}\left[1-(1.025)^{-30}\right]
\end{aligned}
$$


$=89.2 \times 10^{5}(0.5223)$

$=\$ 4.67 \times 10^{6}$

The annualized system cost in the absence of inflation is given by the following simplified version of equation $4-6$ :

$$
\begin{aligned}
A C & =(F C R)\left(C I_{p v}\right)+(C R F)\left(X_{p v}\right) \\
& =(0.0703)\left(22.3 \times 10^{6}\right)+(0.0478)\left(4.67 \times 10^{6}\right) \\
& =\$ 1.79 \times 10^{6}
\end{aligned}
$$

The levelized cost of the $10 \mathrm{MW}$ solar plant is the annualized cost divided by $2.19 \times 10$ ?, the number of kilowatt-hours of energy produced by the plant per year. Thus, the levelized cost of the plant is:

$$
\begin{aligned}
\text { LC } & =1.79 \times 10^{6} / 2.19 \times 10^{7} \\
& =\$ 0.0817 / \mathrm{kWh} \\
& =81.7 \mathrm{mills} / \mathrm{kWh}
\end{aligned}
$$

Figure 4-4 shows a computer printout of the calculation for this specific case. All of the cases examined in the breakeven cost analysis were calculated with the computer program.

A. 10. $\mathrm{MW}$ e oll-fired, municipally-owned, steam-electric plant would cost $36.3 \mathrm{mills} / \mathrm{kWh}$, using a cost of $\$ 1132 / \mathrm{kW}$ (see Table 4-3). The O\&M cost for this plant would be $5.2 \mathrm{mills} / \mathrm{kWh}$, based on an annual expenditure of one percent of the steam plant cost. The steam plant costs were calculated with the ERDA/EPRI methodology using the same procedure as for the solar thermal plant costs. 
INPUT DATA

** UTILITY DESCRIPTION DATA ***

INVESTMENT TAX CREDIT

ANNU XL GTHER TAXES

ANNUAL INSURANCE PREMIUMS

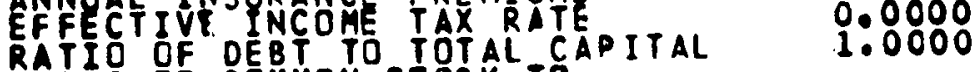

RATIO OF COMMON STOCK TO

RATIO OF PREFERR ED STOCK IÓ

TÓTAL CAPITALIZATION

ANNUAL RATE. OF RETURN ON DEBT

$$
\begin{array}{r}
0.0000 \\
.0200 \\
0.8825 \\
1.80000 \\
0.0000 \\
0.0000 \\
.0250 \\
0.0000 \\
0.0000 \\
30
\end{array}
$$

ANNUAL RATE OF REFURN ON PREFERR ED STOCK

ACCOUNTING LIFE IN YEARS

** GENERAL ECONOMIC CONDITIONS ** *

RATE OF GENERAL INFLATION

ESCALATION RATE FOR CAPITAL COSTS

ESCALATION RAIE FOR MAINTENANCE EOSTS

ESCATATION RATE

ESCALATION RATE FOR FUEL COSTS

BASE YEAP FOR CONSTANT DOLLARS

PRICE YEAR OF COST INFORMATION

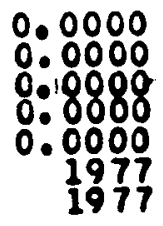

* * system DFscription Cata ***

SYSTEM LIFETIME IN YEARS

RATED PLANT CAPACITY

YEARS CAPITAL INVESTFO

CAPITAL INVESTMENT STREAM NO. 1

ANNUAL MAINTENANCE ZOSTS

ANNUAL OPERATING COSTS

ANNUAL FUEL COSTS

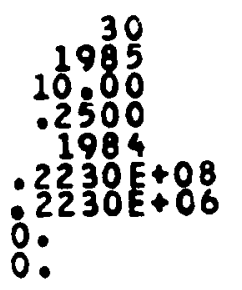

STRAIGHT LINE DEPRECIATION IS USEO THIS CASE ***

\section{CALCULATED RESULTS}

COST OF CAPITAL (DISCOUNT RATE)

CAPITAL RECOVERY FACTOR (SYSTEM LIFE, 30 YEARS)

CAPITAL RECOVFRY FACTOR (ACCOUNTING PERIOD, 30 YEARS)

ANNUALIZED FIXED CHARGE RATE

OEPRECIATION FACTOR

.0250
.0478

.0478

$\because .0703$

PY OF TOTAL CAPITAL INYESTED PSM) $^{M}$

PV OF RECURRING MAINTENANCE CDSTS (\$M)

PV OF RECURRING OPERATING COSTS (SM)

ANNUAL IZER SYSIEM RE SULTANT COSTS (SM)
$22.2 n$

0.00
0.07

o1:79

Figure 4-4. Computer Printout of ERDA/EPRI Calculations for $10 \mathrm{MW}$ Solar Thermal Power Plant in Replacement Mode 
It is necessary to calculate the present value of the fuel savings, produced by the use of a solar thermal power plant in place of a fossil-fueled power plant, external to the ERDA/EPRI cost methodology. This, value of $F L_{p v}$ can then be inserted into equation 4-6, given. In Section 4.3.1.7, to calculate the annualized fuel savings which is then converted to a levelized value in mills per kilowatt-hour of solar plant operation. This procedure is necessary, as discussed earlier in this section, because the Sherman Clark fuel price forecasts are given for separate five-year periods with different fuel price escalation rates whereas the ERDA/EPRI cost methodology accepts only a single-valued fuel price, which is then escalated at a constant rate by the methodology.

The following example illustrates the procedure used to determine the fuel savings in mills per kilowatt-hour in the breakeven cost analysis. Assume, as was the case in the example shown in Section 4.3.1.9, that a $10 \mathrm{MW}_{\mathrm{e}}$ solar thermal power plant is used in the replacement mode for a $10 \mathrm{MW}$ oil-fired steam plant in California in the absence of inflation. The plant is owned by a municipal utility system. Table 4-7 gives the following prices in 1977 dollars/10 Btu for No. 2 fuel oil in California in the 1985-2015 time period:

$\begin{array}{lll}\frac{\text { Year }}{1985} & & \frac{\text { Price }}{13.80} \\ 1990 & & 4.25 \\ 1995 & & 4.74 \\ 2000 & & 5.24 \\ 2005 & & 5.26 \\ 2010 & & 5.28 \\ 2015 & & 5.30\end{array}$


Linear interpolation is used to determine the fuel prices within any given five-year period. The present value of the fuel in any year, $t, 1 s$ :

$$
F L_{p v}=(1+k)^{-(t+1)} F L_{t}
$$

where $t$ is the difference between the year being analyzed and the year 1985, 1.e., for the year 1990, $t=5$. The value of $k$ for a municipal utility in the absence of Inflation is 0.025 , as calculated in section 4.3.1.9. The present value of all the fuel saved in the 30 -year period 1s:

$$
F L_{p v}=\sum_{t=0}^{29}(1+k)^{-(t+1)} \cdot F L_{t} \cdot
$$

Using the data for No. 2 fuel oil shown above, the present value of the 30 -year fuel ofl cost stream is $\$ 99.64$, assuming that a milliton Btu of energy is used each year. The levelized cost of this cost stream is:

$$
\mathrm{LC}_{\mathrm{FL}}=\left(\mathrm{FL}_{\mathrm{pv}}\right)(\mathrm{CRF})(\text { Heat Rate }) \text {, }
$$

where the heat rate is the quantity of heat (Btu) required to produce one kllowatt-hour of electricity in a given fossil-fueled power plant. Values of the heat rate are given in Table 4-3 for steam-electric plants. A value of 14,000 Btu per kilowatt-hour should be used in this calculation for a $10 \mathrm{MW}_{\mathrm{e}}$ oll-fired plant. The capital recovery factor, CRF, was calculated in Section 4.3 .1 .9 and is equal to 0.0478 . Thus, the levelized cost for the fuel savings in dollars per kilowatt-hour is:

$$
\begin{aligned}
\mathrm{LC}_{\mathrm{FL}} & =(99.64)(0.0478)(14,000) \\
& =\$ 0.0667 / \mathrm{kWh} \\
& =66.7 \mathrm{mills} / \mathrm{kWh}
\end{aligned}
$$


The levelized cost for the fuel saving, when combined with levelized costs for the capital investment and $0 \& M$ (i.e., 36.3 and 5.2 , respectively), gives a total levelized cost of $108.2 \mathrm{mills} / \mathrm{kWh}$ for the $10 \mathrm{MW}_{\mathrm{e}}$ oil-fired steam plant.

4.4 RESULTS OF THE BREAKEVEN COST ANALYSIS

This section summarizes the results of the breakeven cost analysis for the 256 sases which were run in the initial set of analyses. Eighty-eight cases were for the repowering mode and 168 cases were for the replacement mode of operation. The larger number of cases in the latter mode is due to the fact that both fossil-fueled steam-electric plants and diesel generators must be considered in replacement while only steam-electric plants are involved in the repowering mode. The matrix of the 240 basic cases is shown in Table 4-8. The values for the variables were given earlier in Table 4-1.

Table 4-8. Matrix of Cases for Breakeven Cost Analysis

\begin{tabular}{|l|c|c|c|c|c|c|c|}
\hline $\begin{array}{c}\text { Operational } \\
\text { Mode }\end{array}$ & State & $\begin{array}{c}\text { Plant } \\
\text { Type }\end{array}$ & $\begin{array}{c}\text { Plant } \\
\text { Size }\end{array}$ & $\begin{array}{c}\text { Type of } \\
\text { Ownership }\end{array}$ & $\begin{array}{c}\text { Type of } \\
\text { Fuel }\end{array}$ & $\begin{array}{c}\text { Inflation } \\
\text { Rate }\end{array}$ & Total \\
\hline Repowering & 5 & 1 & 2 & 2 & 2 & 2 & 80 \\
Replacement & 5 & 2 & 2 & 2 & 2 & 2 & 160 \\
\hline
\end{tabular}

In addition to these $240^{\prime}$ cases, 16 other cases were run only for the State of California to determine the sensitivity of the results to the rate of inflation and to the cost of heliostats. A 7 percent inflation rate was used for $1 \mathrm{MW}$ and $10 \mathrm{MW}$ investor-owned power plants in the two operational modes to develop the data presented earlier 
in Figure 4-2. The effect of heliostat costs of $\$ 50 / \mathrm{m}^{2}, \$ 140 / \mathrm{m}^{2}$, and $\$ 210 / \mathrm{m}^{2}$ (relative to the baseline cost of $\$ 70 / \mathrm{m}^{2}$ ) was examined in the absence of inflation for $1 \mathrm{MW}$ and $10 \mathrm{MW}$ plants in both the repowering and replacement modes.

Also, four cases were run for $1 \mathrm{MW}_{e}$ and $10 \mathrm{MW}$ municipal utility plants in Nevada, the state with the lowest insolation in the "sun belt", with a solar thermal plant starting up in the year 2000 in both the repowering and replacement modes of operation. These cases were to determine the impact of a later starting date on the cost-effectiveness of a solar plant in Nevada, where such plants were not cost-effective in 1985.

The results of the breakeven cost analysis for each of the five "sun belt" states have been grouped in Sections 4.4.1 and 4.4.2, respectively, for municipal and investor-owned power plants. This grouping was chosen in preference to alternative methods of displaying the data because each type of utility system management will have to make its own decision relative to its future purchases of generating equipment. The states are listed in order of decreasing solar insolation values, i.e., California, Texas, New Mexico, Arizona, and Nevada. The format selected to display the calculated cost elements for the busbar costs for a solar power plant lists the data in the following order: levelized capital cost of the solar plant, levelized O\&M cost, and levelized total cost for the plant. For the fossil-fueled power plants, steam-electric and diesel, the levelized fuel saving for the period of operation of the solar plant is shown after the levelized plant capital cost. All levelized costs are based on the capacity factors used in the analysis. When repowering is being analyzed rather than replacement, the levelized capital cost for the fossil-fueled steam-electric power plant is not included in the total levelized busbar cost. 
Comparisons will be made of various effects on plant costs in Section 4.4.3, using data developed for the plants in Sections 4.4.1 and 4.4 .2 .

\subsubsection{Municipal Utility Systems}

Tables 4-9. through 4-13 show the levelized cost data developed for each of the five "sun belt" states for municipally-owned $1 \mathrm{MW}_{\mathrm{e}}$ and $10 \mathrm{MW}$ power plants, using the format described above. The iprimary effects shown by the data are that: (1) economy of scale is the dominant factor; (2) solar plants, as would be expected, are less attractive as the solar insolation decreases; and (3) inflation does not change any overall conclusions, but does make a solar plant more cost-effective compared to a fossil-fueled plant than it would be in the absence of inflation.

4.4.2 Investor-Owned Utility Systems

Tables 4-14 through 4-18 present the levelized costs for investor-owned power plants in the five southwestern states. The three effects mentioned above for municipal power systems also apply to investor-owned systems. A cursory inspection of the relative costs of a municipal and investor-owned plant of the same type and size and located in the same state indicates that the levelized capital costs for a plant are approximately 25 percent lower for the municipally-owned power plant, but that the levelized costs for fuel and $0 \& M$ are roughly equal for the two types of ownerships.

\subsubsection{Discussion of Results}

The most important observation of the breakeven cost analysis is that the effect of economy of scale is so strong for central 
Table 4-9. Levelized Costs for Municipally-Owned Power Plants in California

\begin{tabular}{|c|c|c|c|c|c|}
\hline \multirow[b]{2}{*}{ Plant Size and Type } & \multicolumn{5}{|c|}{ Levelized Cost, Mills per Kilowatt-Hour } \\
\hline & $\begin{array}{l}\text { Capital } \\
\text { Cost }\end{array}$ & $\begin{array}{l}\text { Fuel } \\
\text { Cost }\end{array}$ & $\begin{array}{l}\text { O\&M } \\
\text { Cost }\end{array}$ & $\begin{array}{c}\text { Repowering } \\
\text { Total } \\
\text { Cost } \\
\end{array}$ & $\begin{array}{c}\text { Replacement } \\
\text { Total } \\
\text { Cost }\end{array}$ \\
\hline $\begin{array}{l}\text { No Inflation } \\
\text { - MWe Plant } \\
\text { - Solar, Repowering } \\
\text { - Solar, Replacement } \\
\text { - Diesel, Natural Gas } \\
\text { - Diesel, Oil } \\
\text { - Steam, Natural Gas } \\
\text { - Steam, Oil } \\
\text { 10 MWe Plant } \\
\text { - Solar Repowering } \\
\text { - Solar, Replacement } \\
\text { - Diesel, Natural Gas } \\
\text { - Diesel, Oil } \\
\text { - Steam, Natural Gas } \\
\text { - Steam, Oil }\end{array}$ & $\begin{array}{r}87.6 \\
161.5 \\
12.8 \\
12.8 \\
83.4 \\
83.4 \\
\\
\\
40.4 \\
71.5 \\
9.6 \\
9.6 \\
36.3 \\
36.3\end{array}$ & $\begin{array}{r}-.-- \\
--- \\
42.7 \\
45.7 \\
93.3 \\
100.0 \\
\\
--- \\
--- \\
40.0 \\
42.9 \\
62.2 \\
66.7\end{array}$ & $\begin{array}{r}5.8 \\
10.2 \\
1.4 \\
1.4 \\
5.2 \\
5.2\end{array}$ & $\begin{array}{r}100.1 \\
--- \\
--- \\
--- \\
105.2 \\
111.9 \\
46.2 \\
--- \\
--- \\
--- \\
67.4 \\
71.9\end{array}$ & $\begin{array}{r}--- \\
184.4 \\
57.3 \\
60.3 \\
188.6 \\
195.3 \\
\\
--- \\
81.7 \\
51.0 \\
53.9 \\
103.7 \\
108.2\end{array}$ \\
\hline $\begin{array}{l}\text { 3.5\% Inflation } \\
\text { - } 1 \text { MWe Plant } \\
\text { - Solar, Repowering } \\
\text { - Solar, Replacement } \\
\text { - Diese!, Natural Gas } \\
\text { - Diesel, Oil } \\
\text { - Steam, Natural Gas } \\
\text { - Steam, Oil } \\
\text { 10 MWe Plant } \\
\text { - Solar, Repowering } \\
\text { - Solar, Replacement } \\
\text { - Diesel, Natural Gas } \\
\text { - Diesel, Oil } \\
\text { - Steam, Natural Gas } \\
\text { - Steam, Oil }\end{array}$ & $\begin{array}{r}118.4 \\
218.1 \\
17.4 \\
17.4 \\
112.9 \\
112.9 \\
\\
54.6 \\
96.7 \\
13.0 \\
13.0 \\
49.2 \\
49.2\end{array}$ & $\begin{array}{r}--- \\
--- \\
65.6 \\
70.3 \\
143.5 \\
153.8 \\
--- \\
--- \\
61.5 \\
65.9 \\
95.7 \\
102.6\end{array}$ & $\begin{array}{r}9.0 \\
15.9 \\
2.1 \\
2.1 \\
7.6 \\
7.6\end{array}$ & $\begin{array}{r}137.8 \\
--- \\
--- \\
--- \\
160.9 \\
171.2 \\
63.6 \\
--- \\
--- \\
--- \\
103.3 \\
110.2\end{array}$ & $\begin{array}{r}--- \\
253.9 \\
85.6 \\
90.3 \\
273.8 \\
284.1 \\
\\
--- \\
112.6 \\
76.6 \\
81.0 \\
152.5 \\
159.4\end{array}$ \\
\hline
\end{tabular}


Table 4-10. Levelized Costs for Municipally-Owned Power Plants in Texas

\begin{tabular}{|c|c|c|c|c|c|}
\hline \multirow[b]{2}{*}{$\begin{array}{c}\text { Plant Size and Type } \\
\end{array}$} & \multicolumn{5}{|c|}{ Levelized Cost, Mills per Kilowatt-Hour } \\
\hline & $\begin{array}{l}\text { Capital } \\
\text { Cost }\end{array}$ & $\begin{array}{l}\text { Fuel } \\
\text { Cost }\end{array}$ & $\begin{array}{l}\text { O\&M } \\
\text { Cost }\end{array}$ & $\begin{array}{c}\text { Repowering } \\
\text { Total } \\
\text { Cost } \\
\end{array}$ & $\begin{array}{c}\text { Replacement } \\
\text { Total } \\
\text { Cost }\end{array}$ \\
\hline $\begin{array}{l}\text { No Inflation } \\
\text { - } 1 \text { MWe Plant } \\
\text { - Solar, Repowering } \\
\text { - Solar, Replacement } \\
\text { - Diesel, Natural Gas } \\
\text { - Diesel, Oil } \\
\text { - Steam, Natural Gas } \\
\text { - Steam, Oil } \\
\text { - } 10 \text { MWe Plant } \\
\text { - Solar Repowering } \\
\text { - Solar, Replacement } \\
\text { - Diesel, Natural Gas } \\
\text { - Diesel, Oil } \\
\text { - Steam, Natural Gas } \\
\text { - Steam, Oil }\end{array}$ & $\begin{array}{r}94.8 \\
174.7 \\
13.9 \\
13.9 \\
90.3 \\
90.3 \\
. \\
43.8 \\
77.5 \\
10.4 \\
10.4 \\
39.3 \\
39.3\end{array}$ & $\begin{array}{c}--- \\
--- \\
40.8 \\
45.2 \\
89.2 \\
98.8 \\
\\
\\
--- \\
--- \\
38.2 \\
42.3 \\
59.5 \\
65.9\end{array}$ & $\begin{array}{r}13.5 \\
24.8 \\
1.9 \\
1.9 \\
12.8 \\
12.8 \\
\\
. \\
6.2 \\
11.0 \\
1.5 \\
1.5 \\
5.4 \\
5.4\end{array}$ & $\begin{array}{l}108.3 \\
-\cdots \\
-\cdots \\
-102.0 \\
111.6 \\
\\
50.0 \\
-\because- \\
--- \\
64.9 \\
71.3\end{array}$ & $\begin{array}{r}--- \\
199.5 \\
56.6 \\
61.0 \\
192.3 \\
201.9 \\
\\
--- \\
88.5 \\
50.1 \\
54.2 \\
104.2 \\
110.6\end{array}$ \\
\hline $\begin{array}{l}\text { 3.5\% Inflation } \\
\text { - } 1 \text { MWe Plant } \\
\text { - Solar, Repowering } \\
\text { - Solar, Replacement } \\
\text { - Diesel, Natural Gas } \\
\text { - Diesel, Oil } \\
\text { - Steam, Natural Gas } \\
\text { - Steam, Oil } \\
\text { } 10 \text { MWe Plant } \\
\text { - Solar, Repowering } \\
\text { - Solar, Replacement } \\
\text { - Diesel, Natural Gas } \\
\text { - Diesel, Oil } \\
\text { - Steam, Natural Gas } \\
\text { - Steam, Oil }\end{array}$ & $\begin{array}{r}128.1 \\
236.1 \\
18.8 \\
18.8 \\
122.2 \\
122.2 \\
\\
. \\
59.1 \\
104.7 \\
14.1 \\
14.1 \\
53.2 \\
53.2\end{array}$ & $\begin{array}{r}--- \\
--- \\
62.8 \\
70.3 \\
137.3 \\
152.0 \\
\\
--- \\
--- \\
58.9 \\
65.9 \\
91.5 \\
102.6\end{array}$ & $\begin{array}{r}21.0 \\
38.6 \\
2.8 \\
2.8 \\
18.8 \\
18.8 \\
\\
\\
9.7 \\
17.1 \\
2.3 \\
2.3 \\
8.2 \\
8.2\end{array}$ & $\begin{array}{l}149.1 \\
--- \\
-\because- \\
-156.1 \\
170.8 \\
\\
68.8 \\
\because-- \\
--- \\
99.7 \\
110.8\end{array}$ & $\begin{array}{r}--- \\
274.7 \\
84.4 \\
91.9 \\
278.3 \\
29.3 .0 \\
\\
\\
--- \\
121.8 \\
75.3 \\
82.3 \\
152.9 \\
164.0\end{array}$ \\
\hline
\end{tabular}


Table 4-11. Levelized Costs for Municipally-Owned Power Plants in New Mexico

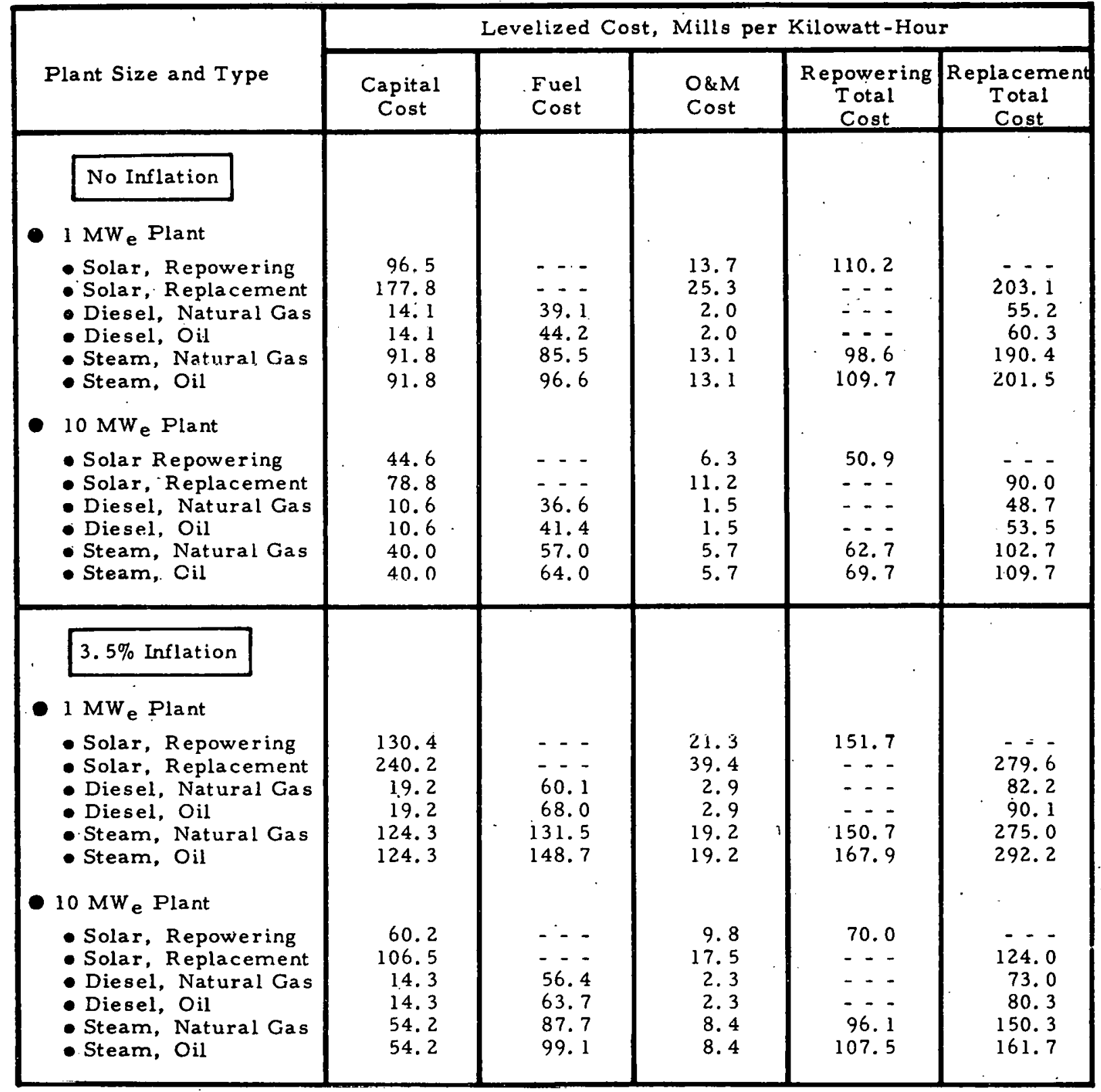


Table 4-12. Levelized Costs for Municipally-Owned Power Plants in Arizona

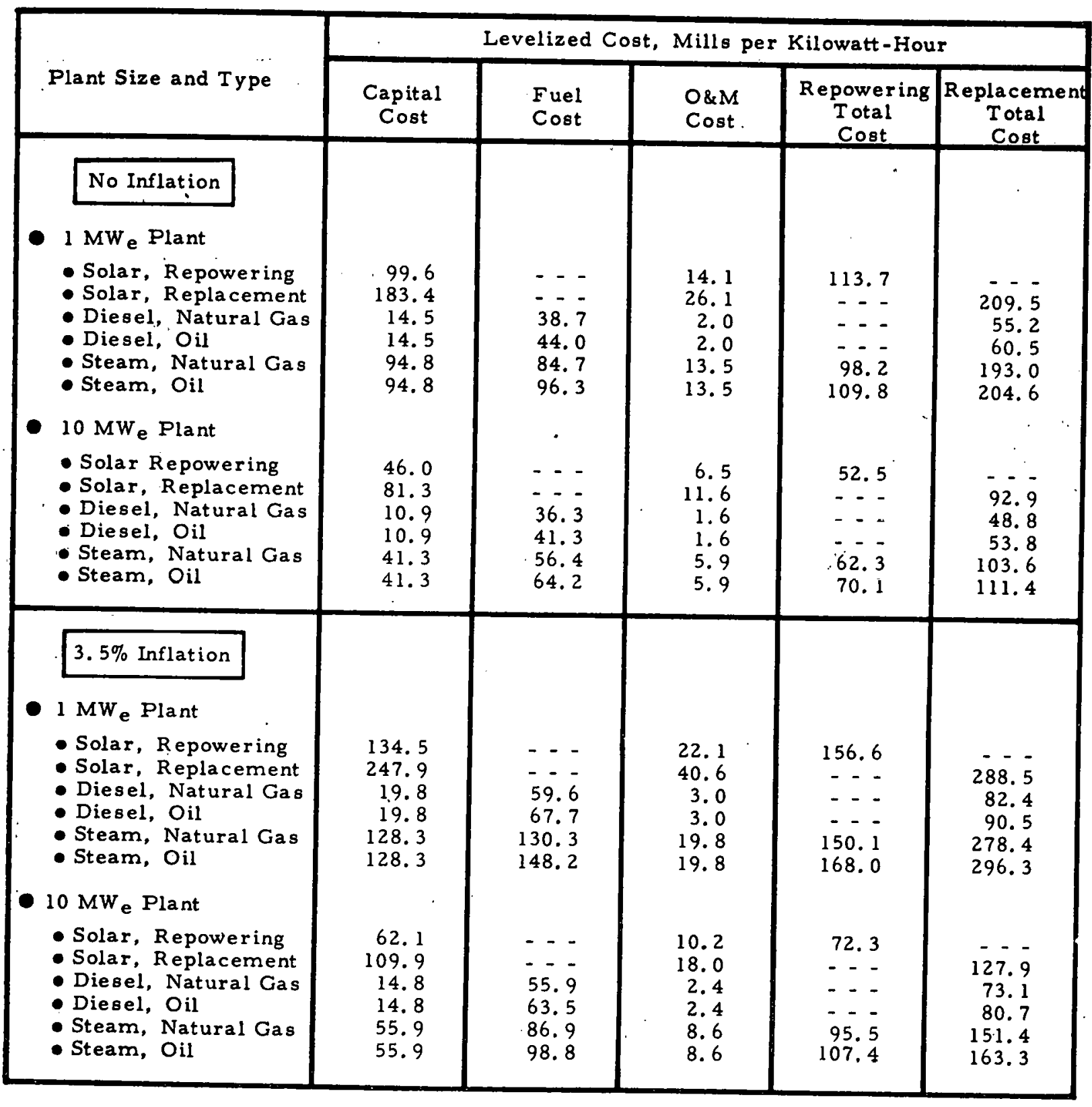


Table 4-13. Levelized Costs for Municipally-Onwed Power Plants in Nevada

\begin{tabular}{|c|c|c|c|c|c|}
\hline \multirow[b]{2}{*}{ Plant Slze and Type } & \multicolumn{5}{|c|}{ Levelized Cost, Mills per Kllowatt-Hour } \\
\hline & $\begin{array}{c}\text { Capltal } \\
\text { Cost }\end{array}$ & $\begin{array}{l}\text { Fuel } \\
\text { Cost }\end{array}$ & $\begin{array}{l}\text { O\&M } \\
\text { Cost }\end{array}$ & $\begin{array}{c}\text { Repowering } \\
\text { Total } \\
\text { Cost } \\
\end{array}$ & $\begin{array}{c}\text { Replacement } \\
\text { T otal } \\
\text { Cost }\end{array}$ \\
\hline 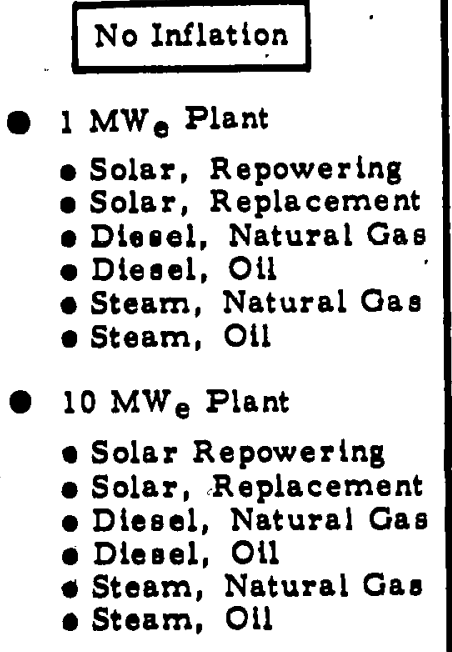 & $\begin{array}{r}103.9 \\
191.3 \\
15.2 \\
15.2 \\
98.8 \\
98.8 \\
\\
\\
47.9 \\
84.9 \\
11.4 \\
11.4 \\
43.0 \\
43.0\end{array}$ & $\begin{array}{l}--1- \\
--- \\
40.3 \\
45.1 \\
88.3 \\
98.8 \\
\\
\because-- \\
--- \\
37.8 \\
42.3 \\
58.8 \\
65.8\end{array}$ & $\begin{array}{r}14.7 \\
27.2 \\
2.1 \\
2.1 \\
14.1 \\
14.1 \\
\\
\\
6.8 \\
12.0 \\
1.7 \\
1.7 \\
6.1 \\
6.1\end{array}$ & $\begin{array}{c}118.6 \\
\because \because . \\
-102.4 \\
112.9 \\
\\
54.7 \\
-\because- \\
-1.9 \\
64.9 \\
71.9\end{array}$ & $\begin{array}{r}-7 .- \\
218.5 \\
57.6 \\
62.4 \\
201.2 \\
211.7 \\
\\
-. .- \\
96.9 \\
50.9 \\
55.4 \\
107.9 \\
114.9\end{array}$ \\
\hline $\begin{array}{l}\text { 3.5\% Inflatlon } \\
\text { - } 1 \text { MWe Plant } \\
\text { - Solar, Repowerlag } \\
\text { - Solar, Replacement } \\
\text { - Diesel, Natural Gas } \\
\text { - Dlesel, Oll } \\
\text { - Steam, Natural Gas } \\
\text { - Steam, Oll } \\
\text { - } 10 \text { MW Plant } \\
\text { - Solar, Repowering } \\
\text { - Solar, Replacement } \\
\text { - Diesel, Natural Gas } \\
\text { - Dlesel, Oil } \\
\text { - Steam, Natural Gas } \\
\text { - Steam, Oll }\end{array}$ & $\begin{array}{r}140.3 \\
258.4 \\
20.6 \\
20.6 \\
133.8 \\
133.8 \\
\\
\\
\\
64.7 \\
114.6 \\
15.4 \\
15.4 \\
58.3 \\
58.3\end{array}$ & 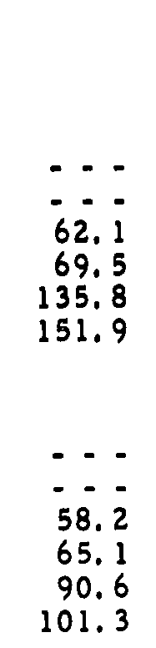 & $\begin{array}{r}23.0 \\
42.4 \\
3.1 \\
3.1 \\
20.6 \\
20.6 \\
\\
\\
10.7 \\
18.8 \\
2.5 \\
2.5 \\
9.0 \\
9.0\end{array}$ & $\begin{array}{r}163.3 \\
\cdots \\
\because \ldots \\
156.4 \\
172.5 \\
\\
75.4 \\
\because- \\
\therefore- \\
-99.6 \\
110.3\end{array}$ & $\begin{array}{r}300 . \overline{-} \\
85.8 \\
93.2 \\
290.2 \\
306.3 \\
\\
\\
-.- \\
133.4 \\
76.1 \\
83.0 \\
157.9 \\
168.6\end{array}$ \\
\hline
\end{tabular}


Table 4-14. Levelized Costs for Investor-Owned Power Plants in California

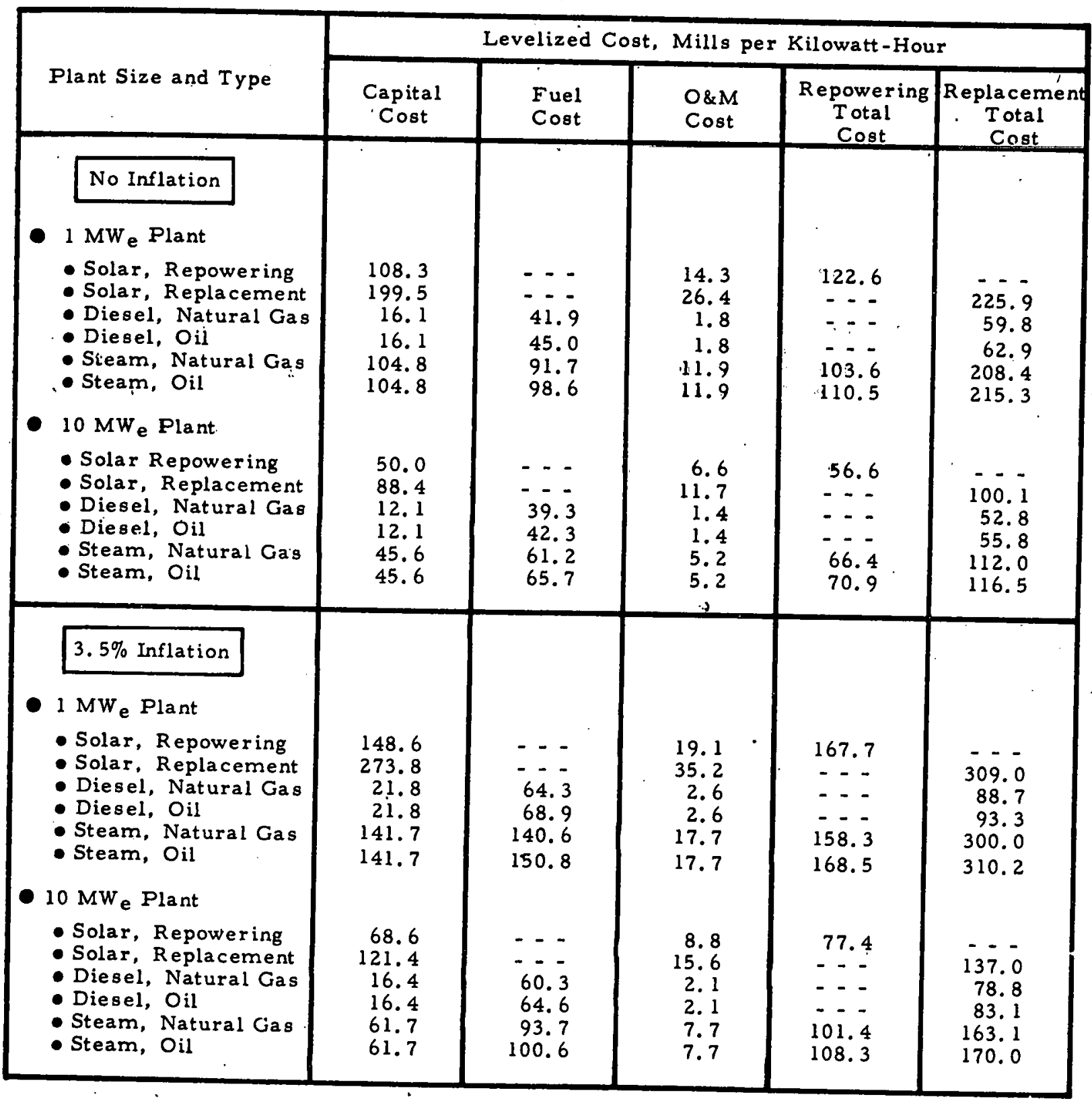


Table 4-15. Levelized Costs for Investor-Owned Power Plants in Texas

\begin{tabular}{|c|c|c|c|c|c|}
\hline \multirow[b]{2}{*}{ Plant Size and Type } & \multicolumn{5}{|c|}{ Levelized Cost, Mills per Kilowatt-Hour } \\
\hline & $\begin{array}{c}\text { Capital } \\
\text { Cost }\end{array}$ & $\begin{array}{l}\text { Fuel } \\
\text { Cost }\end{array}$ & $\begin{array}{l}\text { O\&M } \\
\text { Cost }\end{array}$ & $\begin{array}{c}\text { Repowering } \\
\text { Total } \\
\text { Cost }\end{array}$ & $\begin{array}{c}\text { Replacement } \\
\text { Total } \\
\text { Cost }\end{array}$ \\
\hline $\begin{array}{l}\text { No Inflation } \\
\text { - MW } \text { Plant } \\
\text { - Solar, Repowering } \\
\text { - Solar, Replacement } \\
\text { - Diesel, Natural Gas } \\
\text { - Diesel, Oil } \\
\text { - Steam, Natural Gas } \\
\text { - Steam, Oil } \\
\text { - } 10 \mathrm{MW} \text { e Plant } \\
\text { - Solar Repowering } \\
\text { - Solar, Replacement } \\
\text { - Diesel, Natural Gas } \\
\text { - Diesel, Oil } \\
\text { - Steam, Natural Gas } \\
\text { - Steam, Oil }\end{array}$ & $\begin{array}{r}117.2 \\
215.9 \\
17.4 \\
17.4 \\
113.4 \\
113.4 \\
\\
\\
54.1 \\
95.7 \\
13.1 \\
13.1 \\
49.4 \\
49.4\end{array}$ & $\begin{array}{l}--. \\
--- \\
39.8 \\
44.5 \\
87.1 \\
97.4 \\
\\
--- \\
--- \\
37.4 \\
41.7 \\
58.1 \\
64.9\end{array}$ & $\begin{array}{r}15.5 \\
28.6 \\
1.9 \\
1.9 \\
12.8 \\
12.8 \\
\\
7.1 \\
12.7 \\
1.5 \\
1.5 \\
5.6 \\
5.6\end{array}$ & \begin{tabular}{r}
132.7 \\
$\ldots-$ \\
$\cdots-$ \\
\hdashline 99.9 \\
110.2 \\
61.2 \\
--- \\
$-\cdots$ \\
63.7 \\
70.5
\end{tabular} & $\begin{array}{r}- \\
244.5 \\
59.1 \\
63.8 \\
213.3 \\
223.6 \\
\\
-\overline{-}- \\
108.4 \\
52.0 \\
56.3 \\
113.1 \\
119.9\end{array}$ \\
\hline $\begin{array}{l}\text { 3.5\% Inflation } \\
\text { - } 1 \mathrm{MW} \text { Plant } \\
\text { - Solar, Repowering } \\
\text { - Solar, Replacement } \\
\text { - Diesel, Natural Gas } \\
\text { - Diesel, Oil } \\
\text { - Steam, Natural Gas } \\
\text { - Steam, Oil } \\
\text { - } 10 \text { MWe Plant } \\
\text { - Solar, Repowering } \\
\text { - Solar, Replacement } \\
\text { - Diesel, Natural Gas } \\
\text { - Diesel, Oil } \\
\text { - Steam, Natural Gas } \\
\text { - Steam, Oil }\end{array}$ & $\begin{array}{r}1 \\
160.8 \\
296.3 \\
23.6 \\
23.6 \\
153.3 \\
153.3 \\
\\
\\
74.2 \\
131.4 \\
17.7 \\
17.7 \\
66.8 \\
66.8\end{array}$ & $\begin{array}{r}--. \\
--- \\
64.3 \\
68.9 \\
134.2 \\
149.0 \\
1 \\
--- \\
--- \\
60.3 \\
64.6 \\
89.4 \\
99.3\end{array}$ & $\begin{array}{r}20.7 \\
38.1 \\
2.8 \\
2.8 \\
19.2 \\
19.2 \\
\\
9.6 \\
16.9 \\
2.3 \\
2.3 \\
8.3 \\
8.3\end{array}$ & $\begin{array}{r}181.5 \\
--. \\
-- \\
-- \\
153.4 \\
168.2 \\
83.8 \\
--- \\
-- \\
97.7 \\
107.6\end{array}$ & $\begin{array}{r}--- \\
334.4 \\
90.7 \\
95.3 \\
306.7 \\
321.5 \\
\\
--- \\
148.3 \\
80.3 \\
84.6 \\
164.5 \\
174.4\end{array}$ \\
\hline
\end{tabular}


Table 4-16. Levelized Costs for Investor-Owned Power Plants in New Mexico

\begin{tabular}{|c|c|c|c|c|c|}
\hline \multirow[b]{2}{*}{ Plant Size and Type } & \multicolumn{5}{|c|}{ Levelized Cost, Mills per Kilowatt-Hour } \\
\hline & $\begin{array}{c}\text { Capital } \\
\text { Cost }\end{array}$ & $\begin{array}{l}\text { Fuel } \\
\text { Cost }\end{array}$ & $\begin{array}{l}\text { O\&M } \\
\text { Cost } \\
\end{array}$ & \begin{tabular}{|c|} 
Repowering \\
Total \\
Cost \\
\end{tabular} & $\begin{array}{c}\text { Replacement } \\
\text { Total } \\
\text { Cost }\end{array}$ \\
\hline $\begin{array}{l}\text { No Inflation } \\
\text { - } 1 \text { MWe Plant } \\
\text { - Solar, Repowering } \\
\text { - Solar, Replacement } \\
\text { - Diesel, Natural Gas } \\
\text { - Diesel, Oil } \\
\text { - Steam, Natural Gas } \\
\text { - Steam, Oil } \\
\text { 10 MWe Plant } \\
\text { - Solar Repowering } \\
\text { - Solar, Replacement } \\
\text { - Diesel, Natural Gas } \\
\text { - Diesel, Oil } \\
\text { - Steam, Natural Gas } \\
\text { - Steam, Oil }\end{array}$ & $\begin{array}{r}119.2 \\
219.7 \\
17.7 \\
17.7 \\
115.4 \\
115.4 \\
\\
55.0 \\
97.4 \\
13.3 \\
13.3 \\
50.2 \\
50.2\end{array}$ & $\begin{array}{l}--- \\
---\overline{ } \\
38.0 \\
43.5 \\
83.2 \\
95.2 \\
\\
--.- \\
--\overline{1} \\
35.6 \\
40.8 \\
55.4 \\
63.5\end{array}$ & $\begin{array}{r}15.8 \\
29.1 \\
2.0 \\
2.0 \\
13.1 \\
13.1 \\
\\
7.3 \\
12.9 \\
1.5 \\
1.5 \\
5.7 \\
5.7\end{array}$ & $\begin{array}{r}135.0 \\
\ldots- \\
108.3 \\
96.3 \\
62.3 \\
\cdots-- \\
61.1 \\
69.2\end{array}$ & $\begin{array}{r}--- \\
248.8 \\
57.7 \\
63.2 \\
211.7 \\
223.7 \\
\\
--.- \\
110.3 \\
50.4 \\
55.6 \\
111.3 \\
119.4\end{array}$ \\
\hline $\begin{array}{l}\text { 3.5\% Inflation } \\
\text { - } 1 \text { MWe Plant } \\
\text { - Solar, Repowering } \\
\text { - Solar, Replacement } \\
\text { - Diesel, Natural Gas } \\
\text { - Diesel, Oil } \\
\text { - Steam, Natural Gas } \\
\text { - Steam, Oil } \\
\text { 10 MWe Plant } \\
\text { - Solar, Repowering } \\
\text { - Solar, Replacement } \\
\text { - Diesel, Natural Gas } \\
\text { - Diesel, Oil } \\
\text { - Steam, Natural Gas } \\
\text { - Steam, Oil }\end{array}$ & $\begin{array}{r}163.6 \\
301.5 \\
24.0 \\
24.0 \\
156.1 \\
156.1 \\
\\
\\
75.5 \\
133.7 \\
18.1 \\
18.1 \\
68.0 \\
68.0\end{array}$ & $\begin{array}{l}-.- \\
--- \\
55.0 \\
62.4 \\
85.5 \\
97.1\end{array}$ & $\begin{array}{r}9.8 \\
17.2 \\
2.3 \\
2.3 \\
8.5 \\
8.5\end{array}$ & $\begin{array}{r}184.7 \\
--. \\
-- \\
147.8 \\
165.2 \\
\\
85.3 \\
--- \\
--. \\
94.0 \\
105.6\end{array}$ & $\begin{array}{r}-- \\
340.3 \\
85.6 \\
93.5 \\
303.9 \\
321.3 \\
\\
-- \\
150.9 \\
75.4 \\
82.8 \\
162.0 \\
173.6\end{array}$ \\
\hline
\end{tabular}


Table 4-17. Levelized Costs for Investor-Owned Power Plants in Arizona

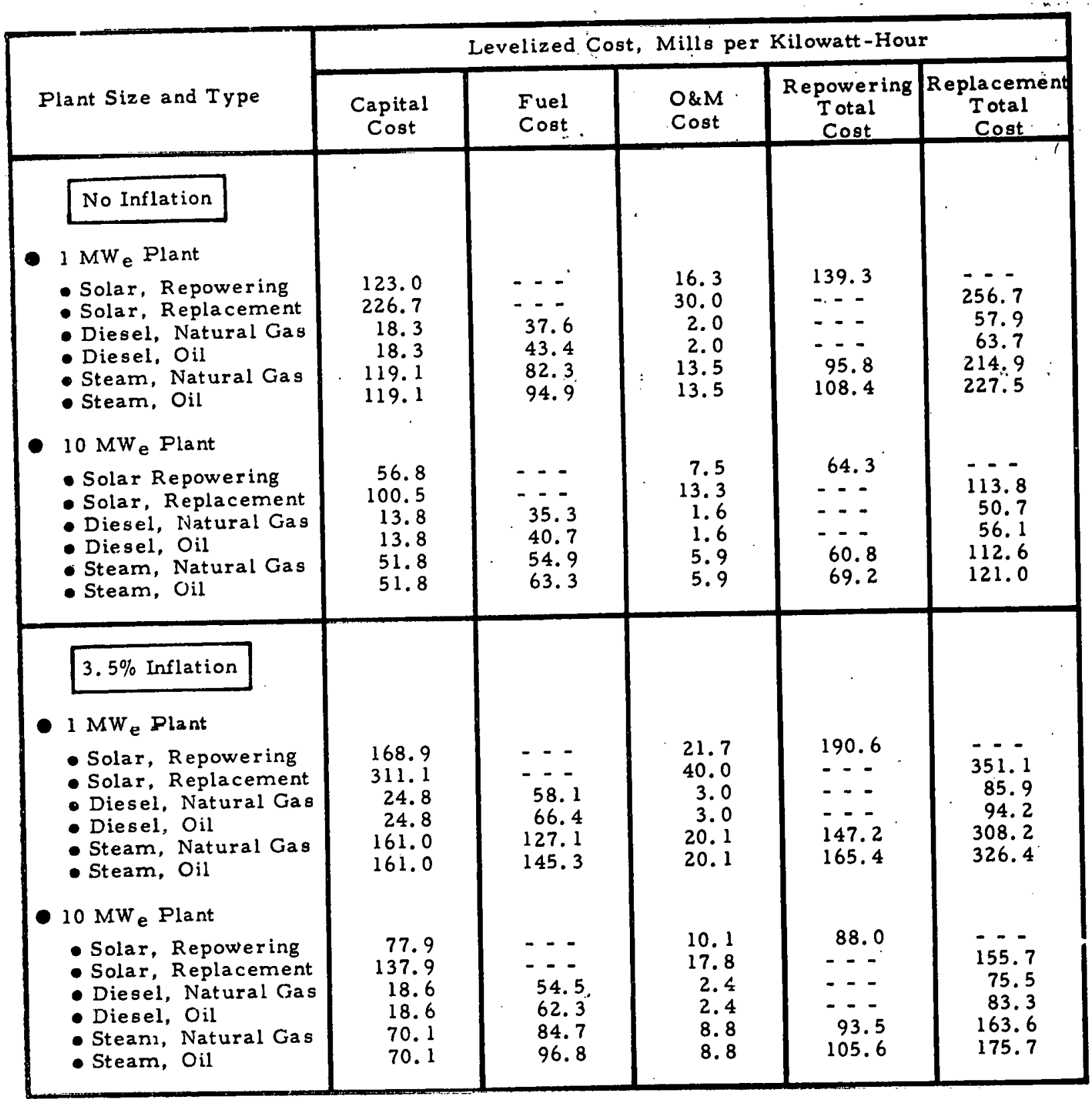


Table 4-18. Levelized Costs for Investor-Owned Power Plants in Nevada

\begin{tabular}{|c|c|c|c|c|c|}
\hline Plant Size and Type & $\begin{array}{c}\text { Capital } \\
\text { Cost }\end{array}$ & $\begin{array}{l}\text { Fuel } \\
\text { Co8t }\end{array}$ & $\begin{array}{c}\text { Millo } \\
\text { O\&M } \\
\text { Cost }\end{array}$ & $\begin{array}{l}\text { Kilowatt - Hou } \\
\text { Repowering } \\
\text { Total } \\
\text { Cogt }\end{array}$ & $\begin{array}{l}\text { Replacemen } \\
\text { Total } \\
\text { Cost }\end{array}$ \\
\hline $\begin{array}{l}\text { No Inflation, } \\
\text { I MWe Plant } \\
\text { - Solar, Repowering } \\
\text { - Solar, Replacement } \\
\text { - Dlesel, Natural Gas } \\
\text { - Diesel, Oll } \\
\text { - Steam, Natural Gas } \\
\text { - Steam, Oll } \\
\text { l, MWe Plant } \\
\text { - Solar Repowerlng } \\
\text { - Solar, Replacement } \\
\text { - Dlesel, Natural Gas } \\
\text { - Diesel, Oll } \\
\text { - Steam, Natural Gas } \\
\text { - Steam, Oll }\end{array}$ & $\begin{array}{r}59.2 \\
104.8 \\
14.3 \\
14.3 \\
54.0 \\
54.0\end{array}$ & $\begin{array}{r}--. \\
39.3 \\
44.5 \\
85.9 \\
97.4 \\
\\
-\ldots .- \\
-76.8 \\
41.7 \\
57.3 \\
64.9\end{array}$ & $\begin{array}{r}17.0 \\
31.3 \\
2.1 \\
2.1 \\
14.1 \\
14.1 \\
\\
\\
7.8 \\
13.9 \\
1.7 \\
1.7 \\
6.1 \\
6.1\end{array}$ & $\begin{array}{l}145.3 \\
-=- \\
=-- \\
100.0 \\
111.5 \\
67.0 \\
-=- \\
=-= \\
63.4 \\
71.0\end{array}$ & $\begin{array}{r}267.6 \\
60.5 \\
65.7 \\
224.2 \\
235.7 \\
\\
=-. \\
118.7 \\
52.8 \\
57.7 \\
117.4 \\
125.0\end{array}$ \\
\hline $\begin{array}{l}\text { 3.5\% Inflation } \\
\text { 1 MW. Plant } \\
\text { - Solar, Repowerlng } \\
\text { - Solar, Replacerient } \\
\text { - Dlesel, Natural Gas } \\
\text { - Dleael, Oll } \\
\text { - Steam, Natural Gas } \\
\text { - Steam, Oll } \\
\text { I0 MWe Plant } \\
\text { - Solar, Repowerlng } \\
\text { - Solar, Replacement } \\
\text { - Dlesel, Natural Gas } \\
\text { - Diesel, Oil } \\
\text { - Steam, Natural Gas } \\
\text { - Steam, Oil }\end{array}$ & $\begin{array}{r}81.3 \\
143.8 \\
19.4 \\
19.4 \\
73.1 \\
73.1\end{array}$ & $\begin{array}{l} \\
-\cdots- \\
--.- \\
56.8 \\
63.8 \\
88.4 \\
99.3\end{array}$ & $\begin{array}{r}10.4 \\
18.5 \\
2.5 \\
2.5 \\
9.1 \\
9.1\end{array}$ & $\begin{array}{l}198.7 \\
-=- \\
=-- \\
153.6 \\
170.9 \\
91.7 \\
-=- \\
-=- \\
-=- \\
97.5 \\
108.4\end{array}$ & $\begin{array}{r}-. . \\
366.1 \\
89.5 \\
97.0 \\
321.5 \\
338.8 \\
\\
--.= \\
162.3 \\
78.7 \\
85.7 \\
170.6 \\
181.5\end{array}$ \\
\hline
\end{tabular}


receiver-type solar thermal power: plants that municipally- and investor-owned $10 \mathrm{MW}$ plants are always cost-effective in the five "sun belt" states in both the repowering "and" replacement modes, whereas $1 \mathrm{MW}_{\mathrm{e}}$ municipally-owned solar thermal plants are cost-effective only in California and Texas in either operational, mode. Table 4-19 summarizes the results of the breakeven cost analysis for the two operational modes relative to oll-fired steam-electric plants and diesel generators in the absence of inflation. The solar thermal plants have no thermal storage and the busbar energy costs are based on hellostat costs of $\$ 70 / \mathrm{m}^{2}$.

The following sections discuss the effect of perturbing the variables on the results of the breakeven cost analysis. The following factors will be discussed: location of the plant (Insolation level), type of ownership, plant size, inflation, heliostat costs, and startup date.

\subsubsection{Effect of Insolation Level}

Figure 4-5 depicts the decrease in the cost-effectiveness of a solar thermal power plant as the solar insolation drops in the five "sun belt" states from $7.85 \mathrm{kWh} / \mathrm{m}^{2} /$ day in California to 6.63 $\mathrm{kWh} / \mathrm{m}^{2} /$ day in Nevada. The sensitivities of the busbar energy costs in the repowering and replacement operational modes are approximately 7.0 and $12.5 \mathrm{mills} \cdot \mathrm{m}^{2} \cdot \mathrm{day} /(\mathrm{kWh})^{2}$, respectively, for a municipally-owned $10 \mathrm{MW}$ plant. The ratio of the sensitivities in the repowering-to-the replacement mode is 0.56 for both municipal and investor-owned solar plants. This indicates that the cost-effectiveness of solar thermal power systems in the repowering mode in states with lower solar insolation will be affected only about six-tenths as much by decreases in the insolation as will the replacement mode. 
Table 4-19. Summary of Regults of Breakeven Cost Analysis

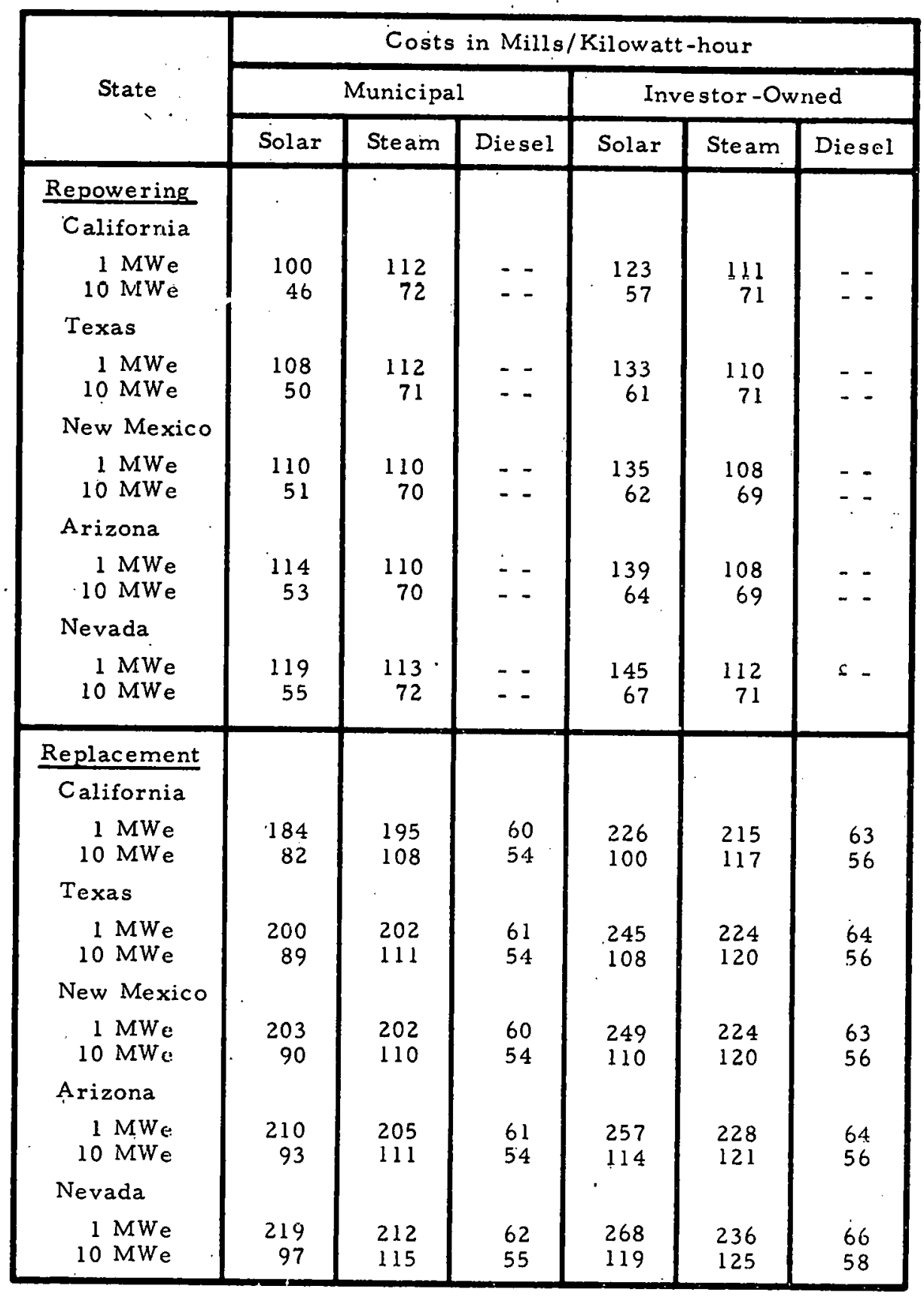



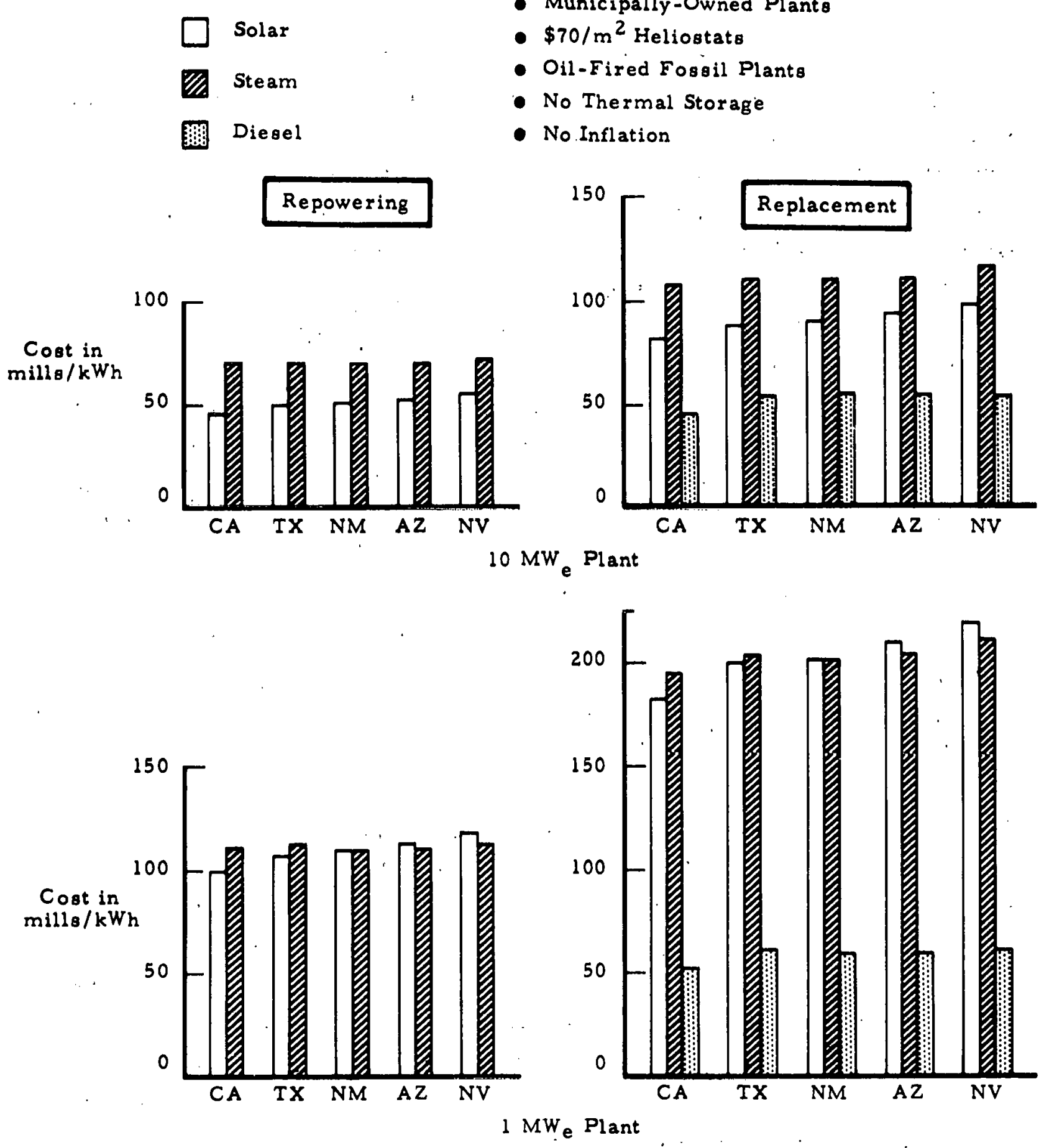

Figure 4-5. Effect of Location on Cost-Effectiveness
- Municipally-Owned Plants

- $\$ 70 / \mathrm{m}^{2}$ Heliostats

- Oil-Fired Fosail Plants

- No Thermal Storage

- No.Inflation 


\subsubsection{Effect of Type of Ownership}

It was pointed out previously in Section 4.4 .2 that, for a municipally-owned power plant of a given power level and type in a given state, the contribution of the levelized capital cost to the total busbar cost of energy is approximately 25 percent lower than for an equivalent investor-owned power plant. On the other hand, the cost of fuel for a conventional power plant is almost equal for the two types of ownership. Therefore, the levelized busbar cost of energy for a municipally-owned power plant will always be cheaper than for an investor-owned plant. Figure 4-6 shows the levelized busbar energy costs in California as a function of plant size and operational mode for the two types of ownership. It should be noted, in this figure, that the levelized fuel costs for the fossil-fueled steam plants almost exactly cancel out the difference in the levelized capital costs for the two types of ownerships in the repowering mode. The figure also shows the relative cost-effeotiveness of $1 \mathrm{MW} e$ and $10 \mathrm{MW} e$ solar thermal power plants in California in the repowering and replacement modes, relative to conventional power plants.

The debt interest rates used in the initial breakeven cost analysis, i.e., 2.5 and 3.5 percent, respectively, for municipal and investor-owned utfilties, result in $10 \mathrm{MW}$ solar thermal power plants that are twice as cost-effective in California for municipalities as for investor-owned systems in both the repowering and replacement modes. The $1 \mathrm{MW}_{\mathrm{e}}$ plants are cost-effective for municipal systems but not for investor-owned utilities. In Nevada, the "sun belt" state with the lowest insolation, $10 \mathrm{MW}$ municipally- and investor-owned solar thermal power plants are cost-effective in both operating modes; municipallyowned and investor-owned $1 \mathrm{MW}$ solar thermal power plants are not cost-effective in e1ther operating mode. 
- Heliostat Cost $\$ 70 / \mathrm{m}^{2}$

- Oil-Fired Fossil Plants

\begin{tabular}{|c|c|c|}
\hline \multirow{2}{*}{$\begin{array}{c}\text { Operational Mode } \\
\text { Plant Size }\end{array}$} & \multicolumn{2}{|c|}{ Cost-Effectiveness } \\
\cline { 2 - 3 } & Municipal & Investor \\
\hline Repowering & & - \\
$1 \mathrm{MW}$ & 1.12 & 0.90 \\
$10 \mathrm{MW}_{\mathrm{e}}$ & 1.54 & 1.25 \\
\hline Replacement & & \\
$1 \mathrm{MW}_{\mathrm{e}}$ & 1.06 & 0.95 \\
$10 \mathrm{MW}$ & .32 & 1.16 \\
\hline
\end{tabular}

Incremental Cost of Capital

Solar

Steam

Diesel

for Investor-Owned Jtility

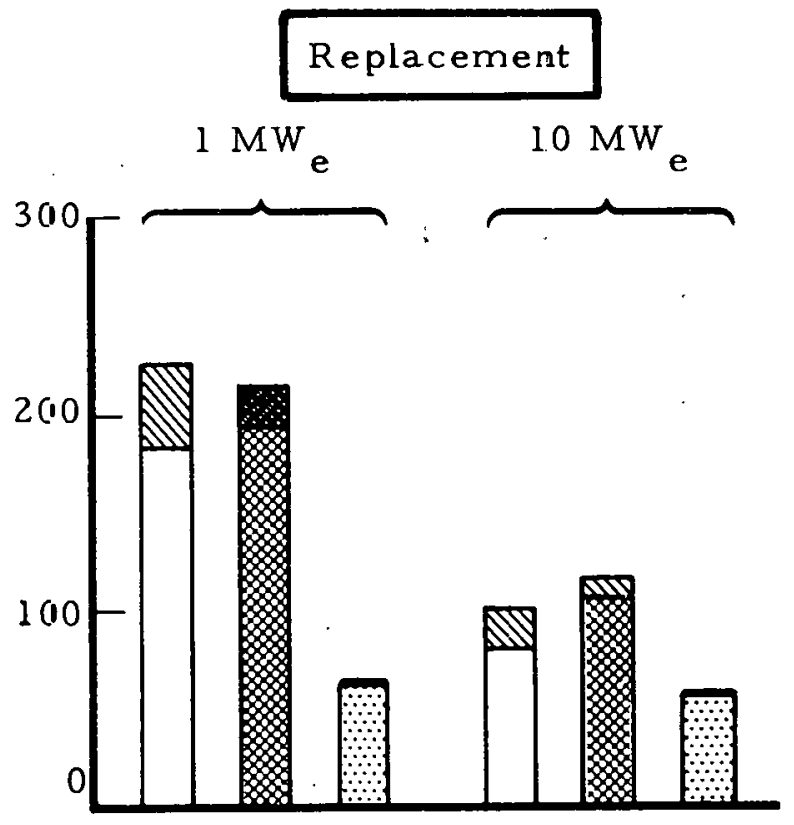

Figure 4-6. Levelizec Energy Costs and Cost-Effectiveness as a Function of Type of Ownership 
Although the owner of either a municipal or investor-owned utility system will reach the same decisions regarding equipment purchases, it is apparent that the lower cost of capital should permit the municipal utility to introduce a solar thermal power system earlier than an investor-owned company. It was shown earlier in this study for different values for the cost of capital than are currently in use, that cheaper capital permitted a municipal. $10 \mathrm{MW}$ solar plant to supply electrical power at about the same cost as an investor-owned $100 \mathrm{MW}_{\mathrm{e}}$ plant, thus overcoming the economy of scale associated with an order of magnitude difference in plant size. This effect is shown qualitatively in Figure $4-7$.

\subsubsection{Effect of Plant Size}

Plant size in the $1 \mathrm{MW}$ to $10 \mathrm{MW}$ range has a greater effect on the results of the breakeven cost analysis than any other variable examined to date. This effect should be smaller for a distributed collector-type solar thermal power system than for the central receiver-type examined in this study if the initial cost projections given in Reference 3 are substantiated in the future. Figure 4-8 shows the effect of plant size for the baseline cases in California in the absence of inflation, and with heliostat costs of $\$ 70 / \mathrm{m}^{2}$ for a municipally-owned plant with no thermal storage capacity; the steamelectric plant and diesel generator both use No. 2 fuel oil as the fuel.

The ratios of the busbar energy costs for $1 \mathrm{MW}$ and 10 MW solar thermal power plants in the repowering and replacement modes, respectively, are 2.17 and 2.26 , irrespective of type of ownership, the presence or absence of inflation, or the "sun belt" state in which the plant is located. Specifically, in California, the levelized busbar energy costs for $1 \mathrm{MW}_{e}$ and $10 \mathrm{MW}$ municipally-owned solar thermal power plants in the repowering mode are 100.1 and $46.2 \mathrm{mills} / \mathrm{kWh}$, using data from Table 4-9 in the absence of inflation. 
Normalized Cost

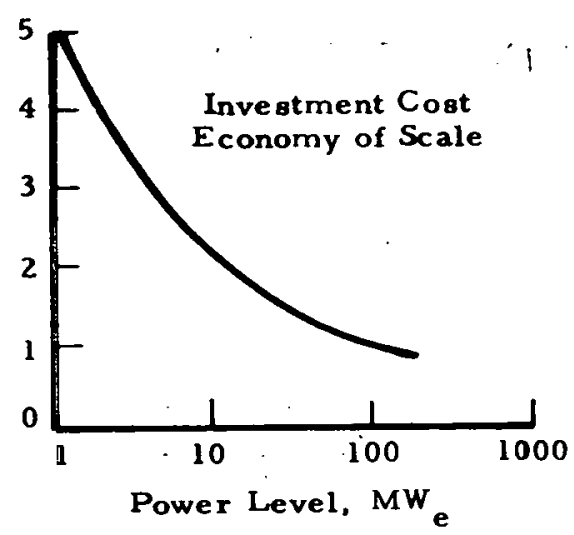

虫

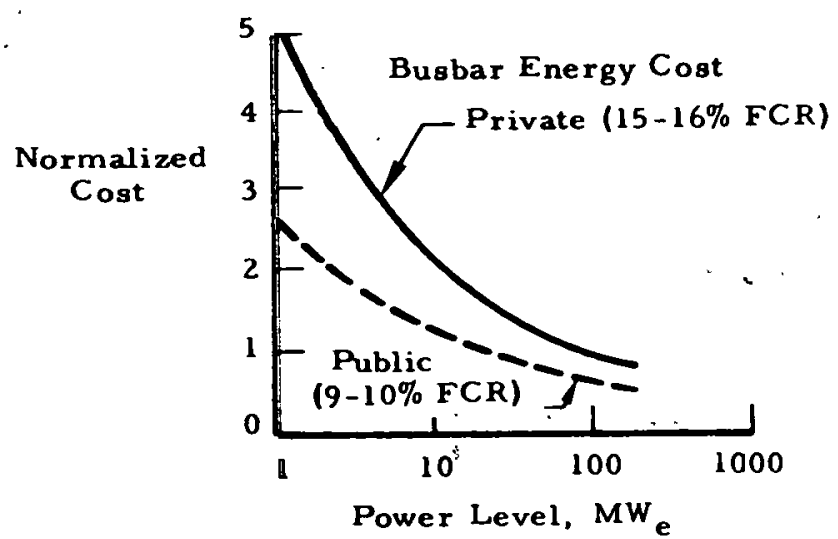

- Investment Per $\mathrm{kW}$ Increases For Small Unite

- Bugbar Energy Cost Increases For Small Unite

- Low Cost Financing Reduces Busbar Energy Costs

- Public Financing Advantage Approximates Small Unit Cost Penalty

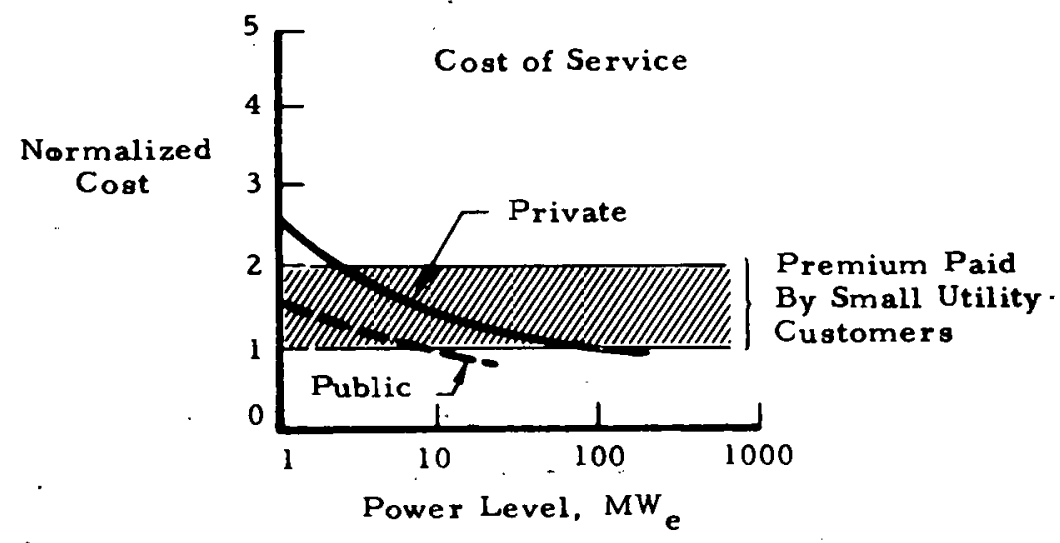

Figure 4-7. Effect of Type of Ownership on Cost of Service 


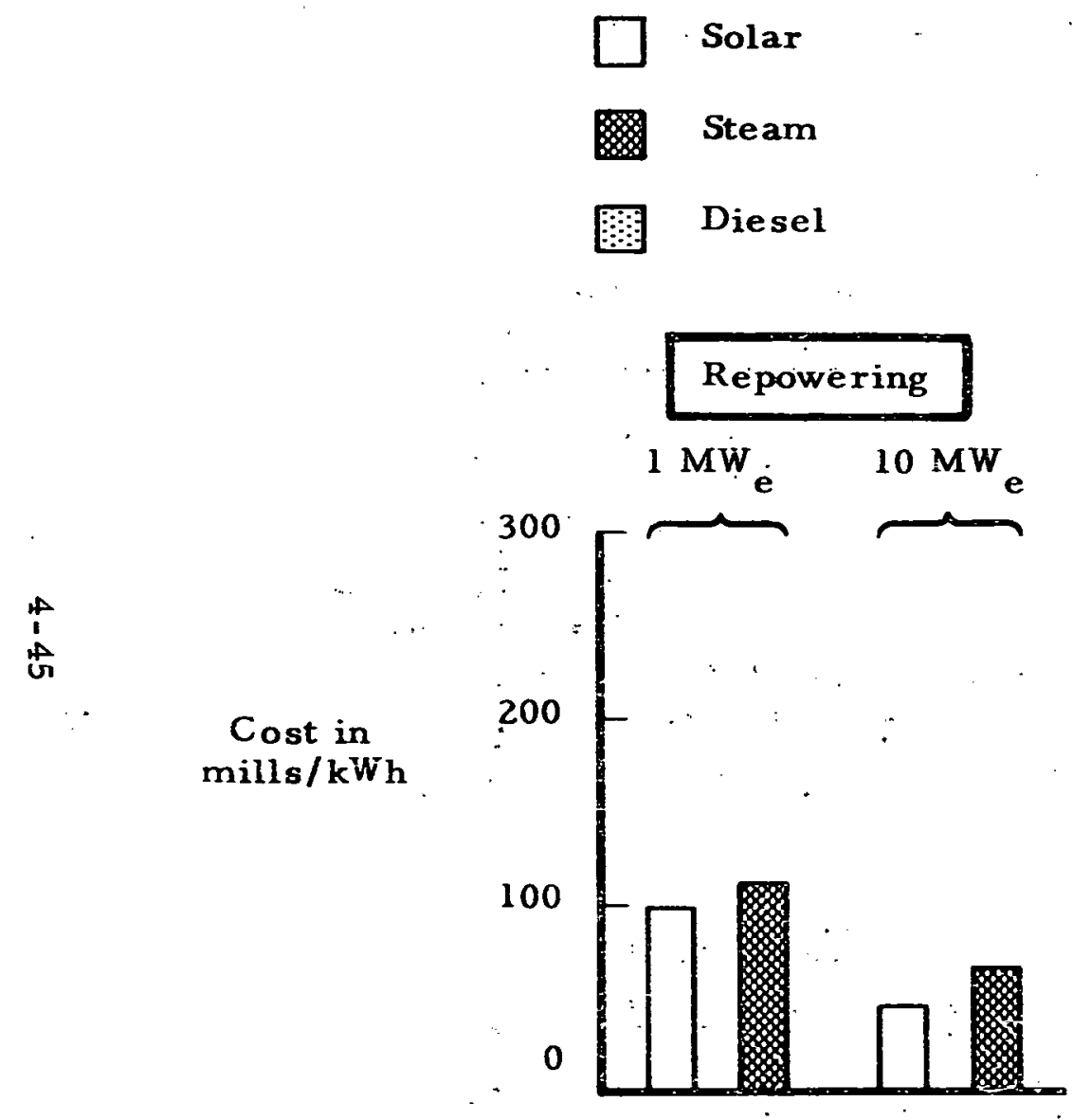

- Californià

- Municipally-Owned Plants

- $\$ 70 / \mathrm{m}^{2}$ Heliostats

- Oil-Fired Fossil Plants

- No Thermal Storage

- No Inflation

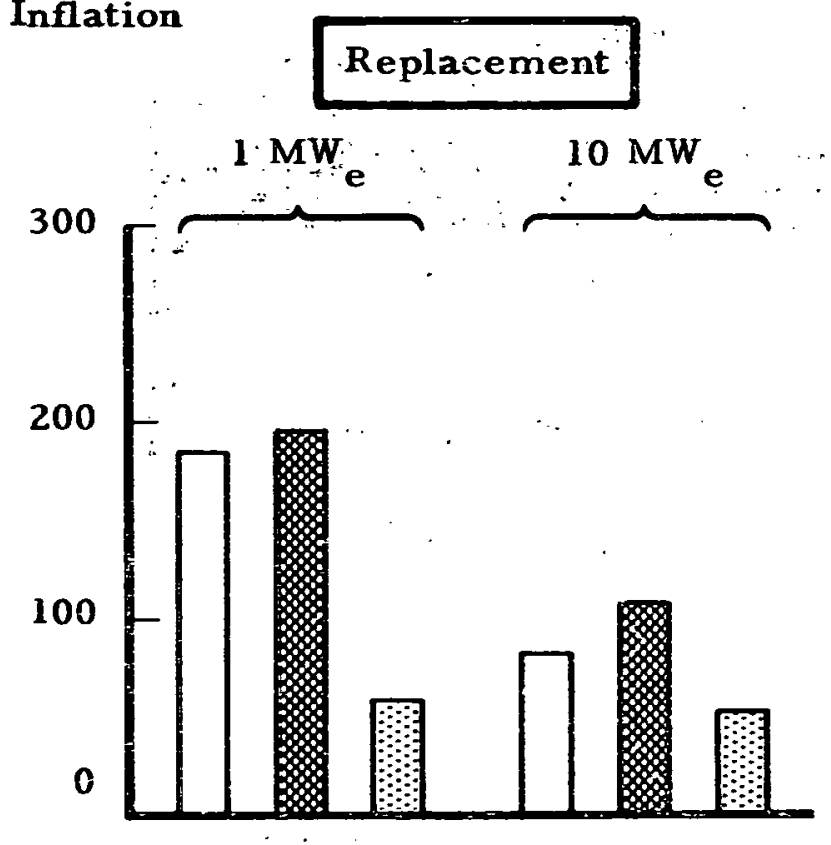

Figure 4-8. Effect of Plant Size on Levelized Energy Costs 


\subsubsection{Effect of Inflation}

As indicated in Section 4.2, the breakeven cost analysis was carried out for all the cases in the absence of inflation and with a 3.5 percent inflation rate. Figure. 4-9 shows the effect of inflation for municipally-owned $1 \mathrm{MW}$ and $10 \mathrm{MW}_{\mathrm{e}}$ solar thermal power plants in California. Inflation has a greater impact on the levelized busbar energy costs of a conventional power plant than on the energy costs of the solar plant because the fuel used by the former is subject to inflation throughout the 30-year plant life, whereas the initial construction costs of the two types of plants are not subject to inflation after the plants are installed. Although inflation results in a higher cost of capital, the attendant increase in the discount rate gives a present value for the cost of capital which is relatively unaffected by inflation.

In general, inflation has no effect on the relative cost-effectiveness of solar thermal and conventional power plants. However, for $1 \mathrm{MW}$ municipally-owned solar thermal power plants in both the repowering and replacement modes in New Mexico, Arizona, and Nevada, the 3.5 percent inflation rate is sufficient to make these plants cost-effective relative to oll-fired steam plants.

\subsubsection{Effect of Heliostat Costs}

The DOE cost goal of $\$ 70 / \mathrm{m}^{2}$ for advanced heliostats was used as the baseline cost for heliostats in the breakeven cost analysis. To determine the sensitivity of the analysis to changes in the heliostat cost, the cost was decreased to $\$ 50 / \mathrm{m}^{2}$ and doubled and tripled to $\$ 140 / \mathrm{m}^{2}$ and $\$ 210 / \mathrm{m}^{2}$, respectively. The analyses turned out to be far less sensitive to the heliostat cost than had been anticipated because this cost amounts to only about 20 and 36 percent of the solar thermal 


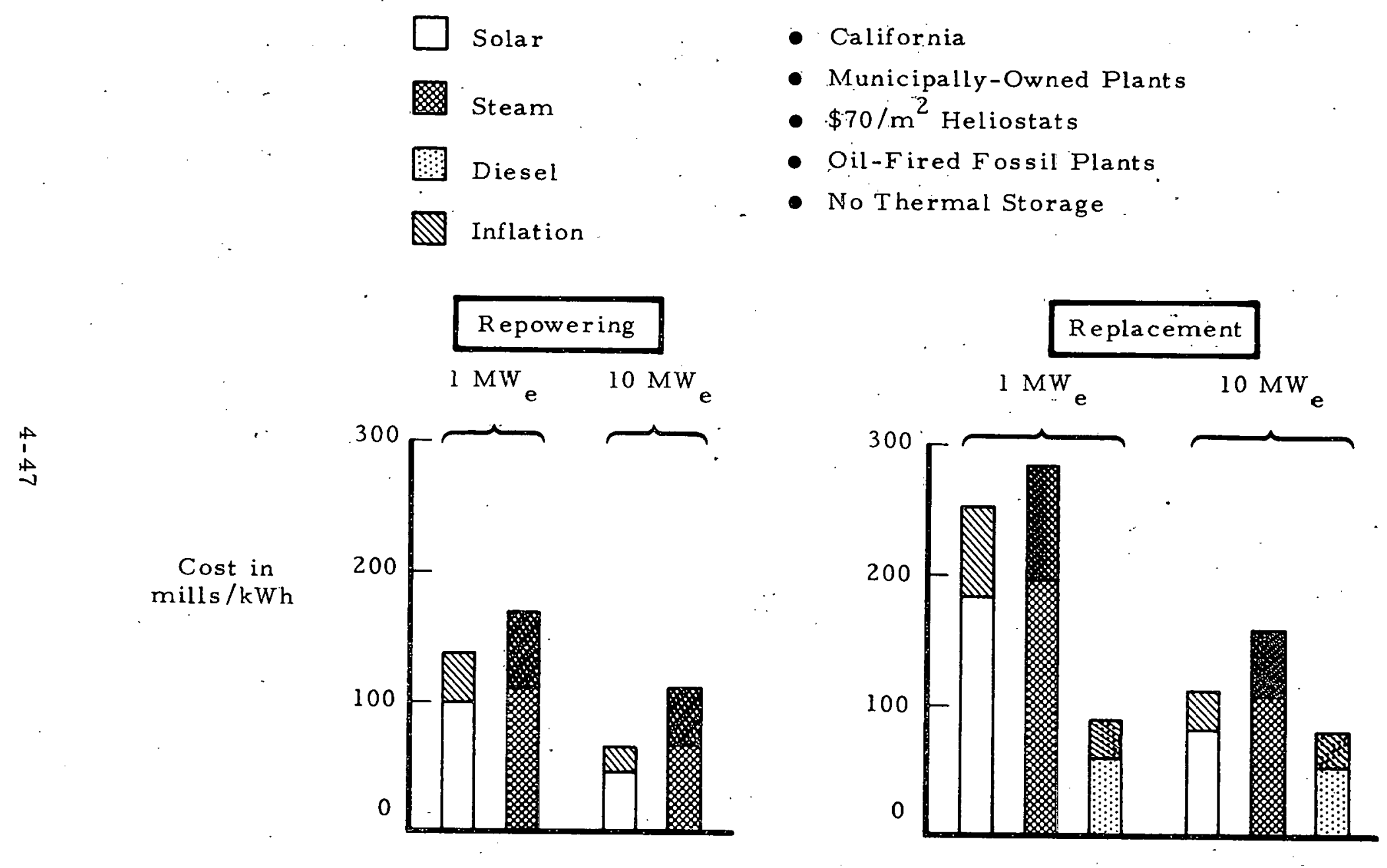

Figure 4-9. Effect of Inflation on Levelized Energy Costs 
power plant cost for $1 \mathrm{MW}_{e}$ and $10 \mathrm{MW}$ plants, respectively, in the repowering mode and to about 11 and 20 percent, respectively, in the replacement mode. The effect of the baseline and alternate heliostat costs on the levelized energy costs of solar thermal power plants is shown in Figure 4-10. The change in the levelized busbar energy cost in mills. $\mathrm{m}^{2} / \$ \cdot \mathrm{kWh}: 1 \mathrm{~s}$ given below in Table $4-20$.

Table 4-20.' Sensitivity of Level1zed: Busbar Energy Cost

To Hellostat Cost

$\therefore$\begin{tabular}{|c|c|c|}
\hline $\begin{array}{c}\text { Plant Size } \\
\left(\mathrm{MW}_{\mathrm{e}}\right)\end{array}$ & \multicolumn{2}{|c|}{ Sensitivity in mills $\cdot \mathrm{m}^{2} / \$ \cdot \mathrm{kWh}$} \\
\cline { 2 - 4 } & Repowering & Replacement \\
\hline 1 & 0.286 & 0.528 \\
10 & 0.132 & 0.234 \\
\hline
\end{tabular}

In California, both $1 \mathrm{MW}_{e}$ and $10 \mathrm{MW}$ municipally-owned solar thermal power plants are cost-effective in either the repowering or replacement modes. Hellostat costs could increase to approximately $\$ 103 / \mathrm{m}^{2}$ for a $1 \mathrm{MW}$ plant or to $\$ 164 / \mathrm{m}^{2}$ for: a $10 \mathrm{MW}$ plant before these solar plants would lose their cost-effectiveness. Investor-owned $1 \mathrm{MW}$ plants are not cost-effective in California and would require a decrease in heliostat costs to about $\$ 45 / \mathrm{m}^{2}$ before they would be cost-effective. Increases in hellostat costs to about $\$ 125 / \mathrm{m}^{2}$ could be absorbed before an investor-owned $10 \mathrm{MW}$ solar plant would lose its cost-effectiveness in California. On the other hand, in Nevada, heliostat costs could only increase to about $\$ 107 / \mathrm{m}^{2}$ before a municlpally-owned $10 \mathrm{MW}$ solar plant in the repowering mode would no longer be cost-effective. 


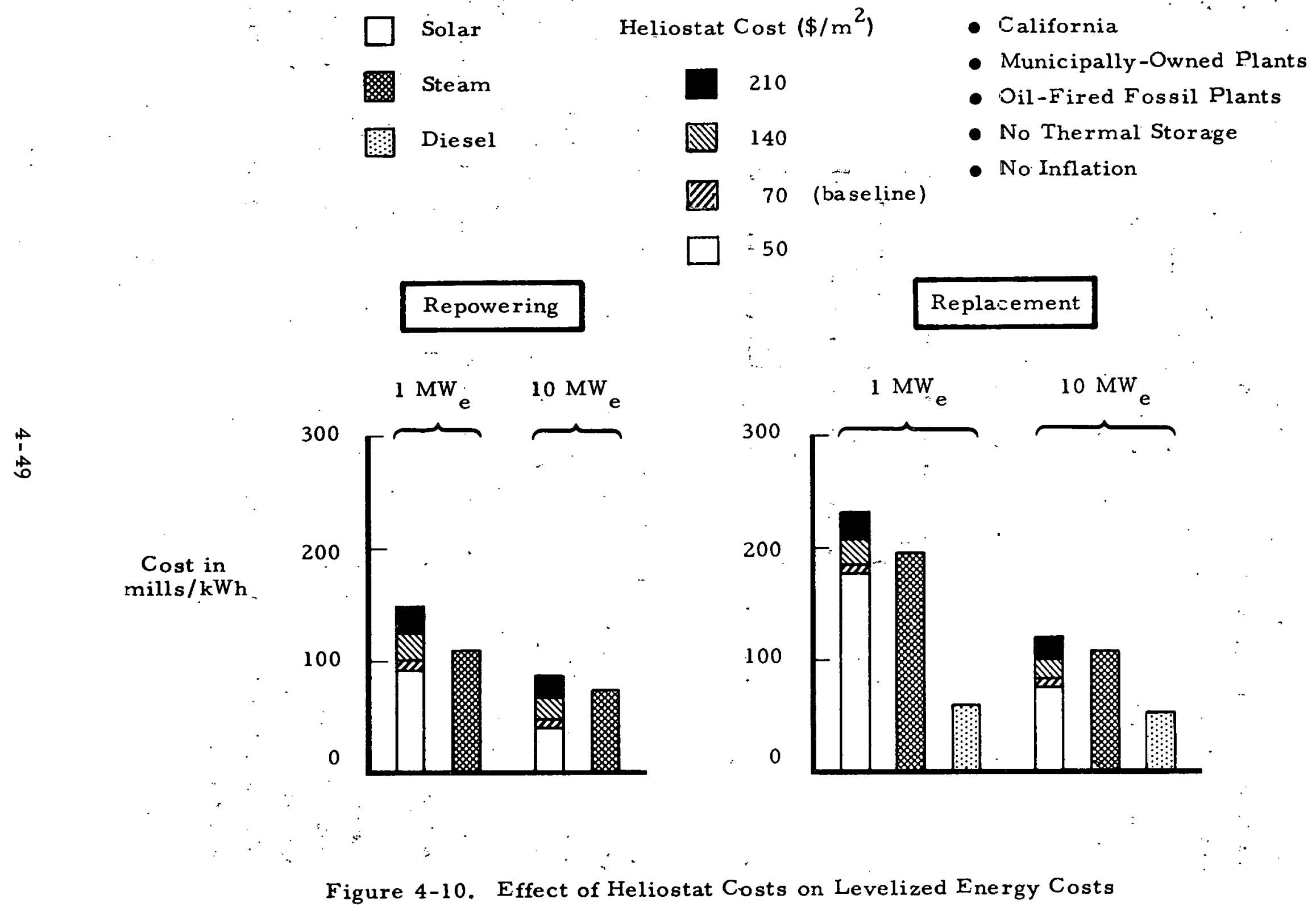




\subsubsection{Effect of Solar Plant Startup Date}

After the initial set of data from the breakeven cost analysis was reviewed, it appeared desirable to examine the impact of a later startup date (w1th higher fuel costs) on the cost-effectiveness of solar thermal power plants in Nevada, the "sun belt" state with the poorest insolation. The Sherman $\mathrm{H}$. Clark Associates fuel price projections through 2015 were extended to 2030, using the 2015 fuel prices for the additional 15 years. The constant value was used for consistency with the methodology used in the Solar Total Energy Systems Study (Reference 13). Table 4-21 shows the comparative levelized costs for No. 2 fuel oil in 1977 dollars for a 30-year fuel stream in municipally-owned $1 \mathrm{MW} e$ and $10 \mathrm{MW}$ steam-electric plants and diesel generators for plant startup dates of 1985 and 2000 , and in the absence of inflation.

Table 4-21. Effect of Plant Startup Date on Fuel 0il Costs

\begin{tabular}{|c|c|c|}
\hline \multirow{2}{*}{ Plant Type } & \multicolumn{2}{|c|}{ Fuel Cost (mills/kWh) } \\
\cline { 2 - 3 } & 1985 Startup & 2000 Startinp \\
\hline Die sel Generator & & \\
$1 \mathrm{MW}_{\mathrm{e}}$ & 45.1 & 50.1 \\
$10 \mathrm{MW}$ & 42.3 & 47.0 \\
Steam Electric & & \\
$1 \mathrm{MW}_{\mathrm{e}}$ & 98.8 & 109.6 \\
$10 \mathrm{MW}_{\mathrm{e}}$ & 65.8 & 73.0 \\
\hline
\end{tabular}

The delay of plant startup from 1985 to the year 2000 does not have any significant effect on the relative cost-effectiveness of a solar thermal power system in Nevada since a solar plant in the repowering mode will only be about 10 percent more cost-effective with 
the higher fuel prices. If the true price of fuel actually continues to increase after 2015, then the delay of the startup date would have a greater impact on the cost-effectiveness of solar thermal power plants.

\subsubsection{Observations on the Breakeven Cost Analysis}

The most important point to be made with respect to the initial set of breakeven cost analysis is that all the results should be viewed as qualitative even though numerical results are shown. This cautionary comment stems from the fact that both the cost and performance data on solar thermal and fossil-fueled steam plants are estimates rather than known quantities, especially at the $1 \mathrm{MW}$ level. With this restriction in mind, certain valid observations can be made regarding the results of the initial breakeven analyses reported here, especially with respect to providing guidance for future analyses to be performed in the follow-on study over the next year.

As pointed out in Section 4.4.3.3, economy of scale in the 1-10 MW $e$ range has the greatest effect of any of the varlables examined so far on this Study. However, at this time, the comments on this effect are valid only for central receiver-type solar thermal power systems since no analyses have been conducted for distributed collector-type solar power systems in The Aerospace Corporation Study, primarily because of the lack of sufficient data on distributed collectors.

The analyses conducted to date indicate that, for a 1985 startup, a municipally-owned $1 \mathrm{MW}$ central receiver is not costeffective relative to an oll-fired steam-electric plant in either the repowering or replacement operational modes, except in California and Texas. On the other hand, both municipally- and investor-owned $10 \mathrm{MW}_{\mathrm{e}}$ solar thermal power plants are cost-effective in all flve "sun belt" states in both the repowering and replacement modes. 
During the next year, work should be carried out to validate and/or improve the cost estimating relationships for both the central receiver- and distributed collector-type of solar thermal power plants in the 1-10 $\mathrm{MW}$ e power range. In addition, once improved cost data are available for both types of solar thermal power systems, analyses should be performed over the entire power range to determine the relative cost-effectiveness of the two types of systems as a function of power level since each type may be more effective than the other at different power levels.

The operational mode of the solar thermal power plant is the next most important factor indicated by the breakeven cost analysis. Without thermal storage, the only case examined to date in this Study, a solar plant in the repowering mode is always more cost-effective than one in the replacement mode, primarily because capital costs are significantly lower in the repowering case. On the basis of the analysis for the five southwestern "sun belt" states, the levelized busbar cost of energy for a solar thermal power plant in the repowering mode without thermal storage is only about half as sensitive to decreases in the solar insolation level as a plant in the replacement mode. During the coming year, the andysis will be extended to other states with lower solar insolation levels to determine the market potential for small solar thermal power systems in those states. The analysis will also examine the effect of different levels of thermal storage on the cost-effectiveness of solar thermal power systems.

On the basis of the Sherman H. Clark fuel price projections, natural gas and No. 2 fuel oll prices will not vary by more than a few percent from state-to-state in any given region of the United States in the post-1985 time period; therefore, reglonal fuel price variations should not have a significant effect on the results of the study. As a result, variations in the solar insolation from state-to-state or within 
a state are deemed to be more important in determining where small solar thermal power systems will be most cost-effective.

Although the delay from 1985 to the year 2000 in the Introduction of solar thermal power systems produced only a 11 peroent increase in the levelized cost of No. 2 fuel oil in Nevada both with and without inflation, it is to be expected that the market penetration by small solar thermal power systems should be quite sensitive to increases in petroleum-based fuel prices," especially in those areas where the fossil-fueled electrical plant is only marginally better than a solar thermal power system.

It will be important to investigate the relative costeffectiveness of small solar thermal and fossil-fueled steam-electric plants in states (and regions within states) with increasingly lower direct insolation levels than Nevada to determine at what insolation levels small solar thermal power plants can no longer compete with o1l-fired steam-electric plants in the 1985-2000 t1me period. This task will be one of the chief efforts during the follow-on study, at least insofar as utility system applications are concerned. 


\section{DEPARTMENT OF DEFENSE APPLICATIONS}

In February 1978, it was suggested that The Aerospace Corporation assist the Jet Propulsion Laboratory in trying to identify a second application for an experimental solar thermal power system. Department of Defense (DOD) electric utility systems for military bases appeared to reprcoent sunh's potential application and it was agreed that The Aerospace Corporation would look into this application area.

Contact was made with Office of the Director for Energy, Assistant for Technical Application, in the Department of Defense to identify the cognizant DOD personnel in the Departments of the Army, Navy, and Air Force, who are responsible for their service's utility systems operations. The points of contact in the three services are as follows :

$\begin{array}{ll}\text { Army } & \text { Utilities Operations Division } \\ \text { Navy } & \text { Navy Facilities Engineering Command } \\ \text { Air Force } & \text { Director of Civil Engineering }\end{array}$

Inquiries to these military services revealed that there are no Army or Air. Force bases in the continental United States which generate their own power, although all bases have emergency power-generating capabilities. Only Fort Greely, Alaska, generates its own power, worldwide, within the Army. All Air Force bases, worldwide, purchase their power if they have access to a commercial power grid. At some island locations, which also have Navy installations, the Air Force purchases its power from the Navy (e.g., Guam). The Navy generates its own power at seven island bases where there is insufficient or no commercially available power and also at a few Conus bases, for a total of 12 installations. The Navy installations use the steam for process 
heat as well as for electrical power. Comments from Army and Navy Department personnel indicate that these two services ceased their electric utility operations after World War II because they could purchase power more cheaply than they could generate 1t. On the basis of the information accumulated to date on DOD power generation at military bases, 1t does not appear that DOD military bases, per se, represent a generic class of applications for small solar thermal power systems.

Nevertheless, it seemed reasonable that remote mllitary bases, especially in the Pacific or Caribbean areas, might offer a cost-effective location for an experimental solar thermal power system. A check was made with the Air Foroe's Director of Civil Engineering at Bolling Air Force Base to determine if there were any, Air Force bases which generated their own power at a remote location in one of these two areas, where the solar insolation was expected to be of high quality. A computer listing of Air Force installations in these areas was obtalned, which indicated that several installations had generating capacity, but that the capacity was too small in most cases. The Northwest Guam Air Force Base (NGAFB) was selected for analysis as the site for a potential experimental solar thermal power system because it was one of the few locations with at least one megawatt of generating capacity and sufficient avallable land to install the necessary solar collectors. (Ramey Air Force Base, Puerto Rico, was the other primary contender). In addition, it was thought that the relative remoteness, of Guam would result in higher fuel costs at Guam than in Puerto Rico.

Discussions were held with personnel of the Deputy Chief of Staff for Engineering and Services of the Strategic Air Command. (SAC), the operating agency for the NGAFB, to obtain information about the Base. The $1820 \mathrm{~kW}$ of generating capacity at NGAFB is provided by four diesel generators, three rated at $440 \mathrm{~kW}$ and one with a capacity of $500 \mathrm{~kW}_{\mathrm{e}}$. Normally, only one diesel is operating at any time. In 
addition, there is a $20 \mathrm{MW}$ gas turbine available as a backup source of power. The Defense Fuel Management System provides the diesel fuel to NGAFB at a cost of $\$ 0.43$ per gallon, a much lower price than anticipated. The Navy has $162 \mathrm{MW}$ of generating capacity on Guam, but did not appear to be providing power to NGAFB at the time the study of this application was started. It now appears that the Navy does supply power to NGAFB with the diesels representing a source of emergency power.

SAC personnel pointed out that there is an adequate supply of unused land available for the installation of solar collectors at NGAFB. Figures 5-1 and 5-2, respectively, show the location of NGAFB on Guam and the general layout of the Base, which is largely unused at present. Qualitative information from SAC personnel, who had been to Guam recently, indicated that good quality insolation could be expected at NGAFB. Climatic data were obtained from the Air Force Environmental Technical Applications Center (ETAC) through SAC. These climatic data were taken at three-hour intervals from 1948 to 1970 in the form of "percent of sky cover" at Andersen Air Force Base, a few miles from NGAFB.

SOLAR INSOLATION DATA

The ETAC climatic data were reviewed by Aerospace Corporation personnel responsible for preparing solar insolation data for use in all the solar energy studies performed by The Aerospace Corporation. Data on Guam were also available from the National Oceanographic and Atmospheric Administration (NOAA) in the form of Annual Summaries containing sunshine data and sky cover values. However, no direct or global insolation measurement at Guam are known to exist.

The Aerospace Corporation derived estimates of the monthly direct solar insolation values for Guam using simple relationships 


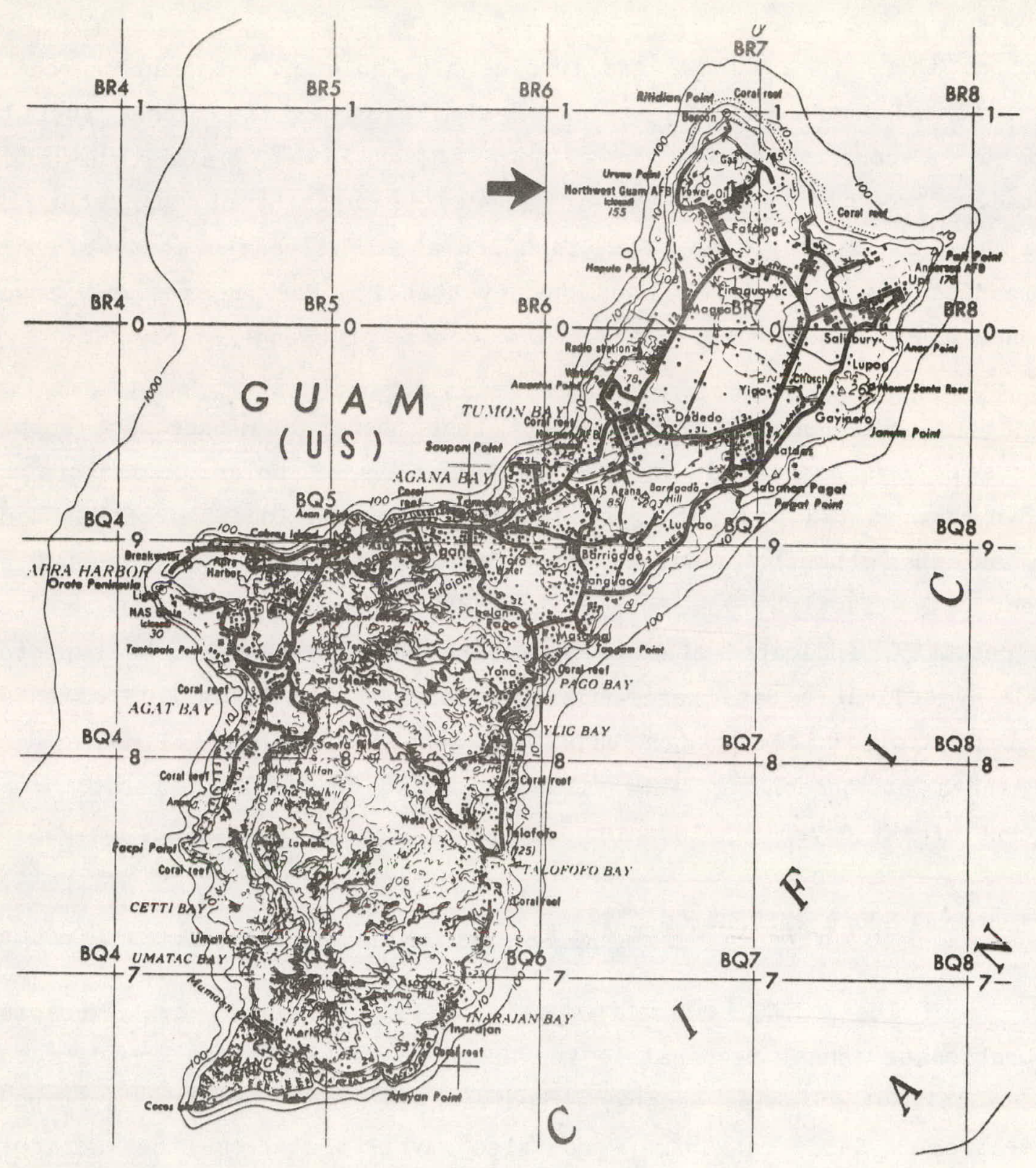

Figure 5-1. Location of Northwest Guam Air Force Base 


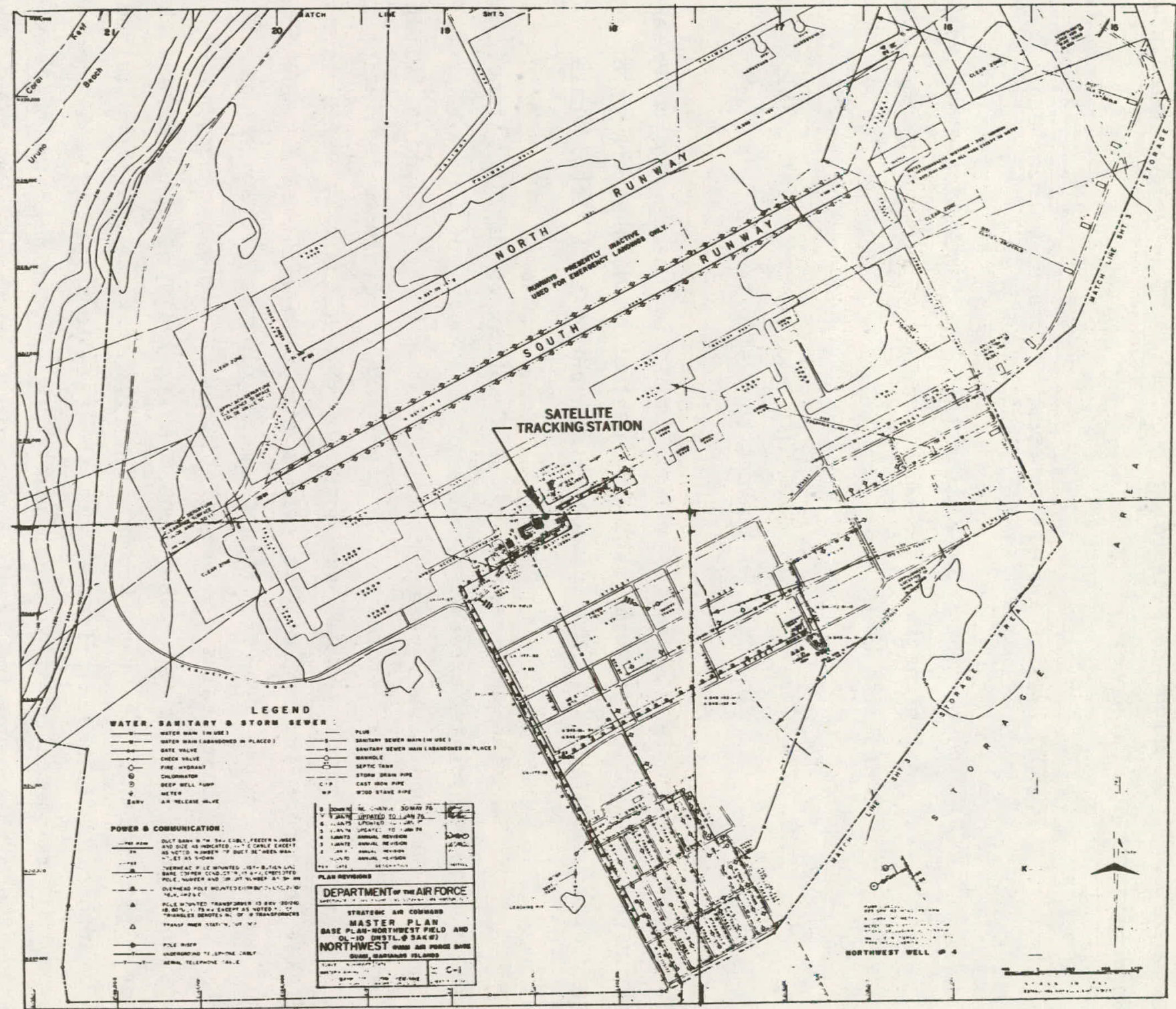

Figure 5-2. Northwest Guam Air Force Base 
between U.S. insolation and meteorological data. These values have large uncertainties arising from:

1. The lack of insolation observations at or near Guam;

2. The necessary assumption that the insolation-cloud cover relationship based upon contiguous U.S. data really do apply to Guam; and

3. The limited data base from which such relationships can be calculated in a short term effort.

Two distinct efforts to predict global insolation using sky cover and sunshine were applied to Guam, including evaluation of the work by others to derive insolation distributions or relationships on a global scale.

Sunshine data represent the fraction of daylight time that the direct insolation exceeds a value of the order of $210 \mathrm{~W} / \mathrm{m}^{2}$, based upon U.S. Weather Bureau measurements with the Foster Sunshine Switch. The sunshine data are related to the total amount of direct insolation in a very complex manner. Total sky cover is also a quantity which is not linked to direct insolation levels in a simple way. Total sky cover is an estimate made by a trained meteorologist from visual sky observations. It contains the normal biases of a human observer and is not an objective physical measurement. An analysis of sunshine and sky cover measurements for Guam, Brownsville (Texas), Honolulu, Wake Island, and Anchorage (Alaska) indicates that the relationships between the two types of measurements vary considerably with location, and that Guam shows the highest sunshine levels for a given amount of sky cover. The data strongly indicate that the relationships between the two types of measurements should be used with caution. 
Two techniques" are avallable to estimate direct insolation, given a set of sunshine and sky cover data. The first uses a simple correlation between global insolation and sunshine:

$$
Q / Q_{0}=a+b \cdot \text { sunshine, }
$$

where $Q$ is the mean dally global insolation and $Q_{0}$ is the extraterrestrial global insolation, which is used by Lof et al. (Reference 14). The second relationship for global insolation is given by Reed (Reference 15) as:

$$
Q / Q_{0}=1-0.62 \cdot C+0.019 \propto,
$$

where $C$ is the total sky cover and $\propto$ is the solar altitude in degrees and serves to correct for cloud projection factor variations at different times of the year or different latitudes. Neither of the two approaches give a relationship for direct insolation.

Lof's and Reed's methods were evaluated by applying them to locations where they can be tested with reliable insolation values. For slmplicity, Brownsville, Texas, and Miami, Florida, were chosen. Lof's sunshine 'method works well for Brownsville, estimating the direct insolation value to 1.5 percent. However, since Brownsville data were used to estimate the $a$ and $b$ in the linear relationship and since the values for $a$ and $b$ are given in Reference 14, the agreement is not surprising. Reed's method gives very large errors, 48 and 43 percent, respectively, for Miami and Brownsville global insolation values.

Sky cover and sunshine data from the NOAA Annual' Summaries can be combined with the SOLMET augmented data base (Reference 16)' to derive correlations with direct and global insolation. These correlalations were derived for Miami and Brownsville and then applied to Guam. 
Considerable variation exists between the sky cover and sunshine values, yielding mean annual direct values of 2.26 and $4.05 \mathrm{kWh} / \mathrm{m}^{2} /$ day, respectively, based on sky cover and sunshine values. Lof's method gives a value of $4.80 \mathrm{kWh} / \mathrm{m}^{2} /$ day.

There is no absolute way to choose between the four estimation techniques on the basis of available data. The sunshineinsolation relationship, based upon the Brownsville data, is judged to be best. Reed's method fails to give reasonable values for locations where it can be tested and where it would reasonably be expected to work. Lof's method may work, but lacks a firm empirical basis for its linear regression variables $a$ and $b$ over much of the global surface. Brownsville-Miami-derived sky cover-insolation relationships predict insolation levels which seem too low, the value of $2.26 \mathrm{kWh} / \mathrm{m}^{2} /$ day estimated for Guam, being about 20 percent lower than the annual average at Seattle. The most plausible set of estimates, the Brownsville insolation-sunshine correlations, predict an annual average direct insolation for Guam which is very nearly the same as for Miami.

Table 5-1 and Figure 5-3 present the recommended insolation values for Guam, baocd on the Browneville sunshine sorrelations with direct and global insolation. These values were chosen as the best estimates for the following reasons:

1. They are based upon values of direct insolation obtained using a model which is regarded to be quite accurate (Reference 16);

2. They do not have the projection factor uncertainties associated with the cloud cover correlation model;

3. They do not contain the assumption that cloud characteristics are similar for Brownsville and Guam; 
Table 5-1. Recommended Design Values for Guam Insolation

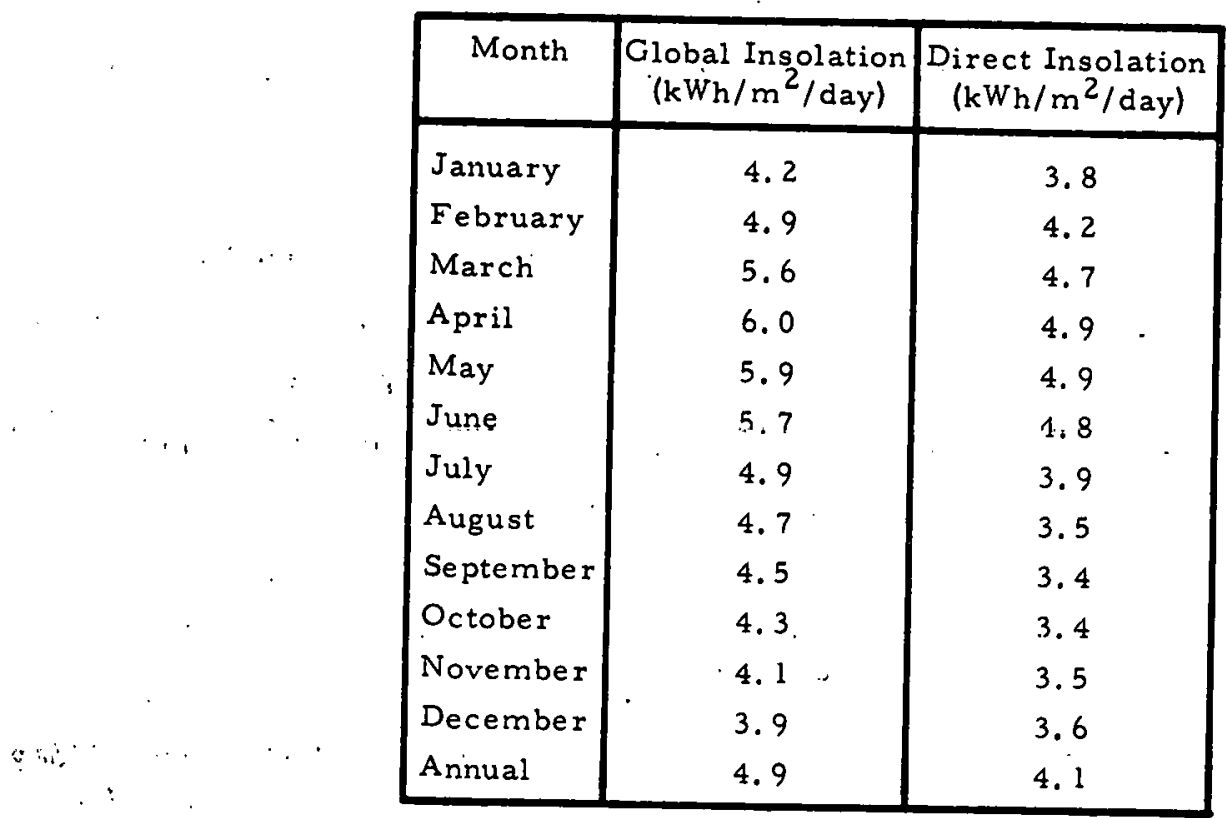

Uncertainties of at least plus or minus 20 percent should be assumed for these estimates.

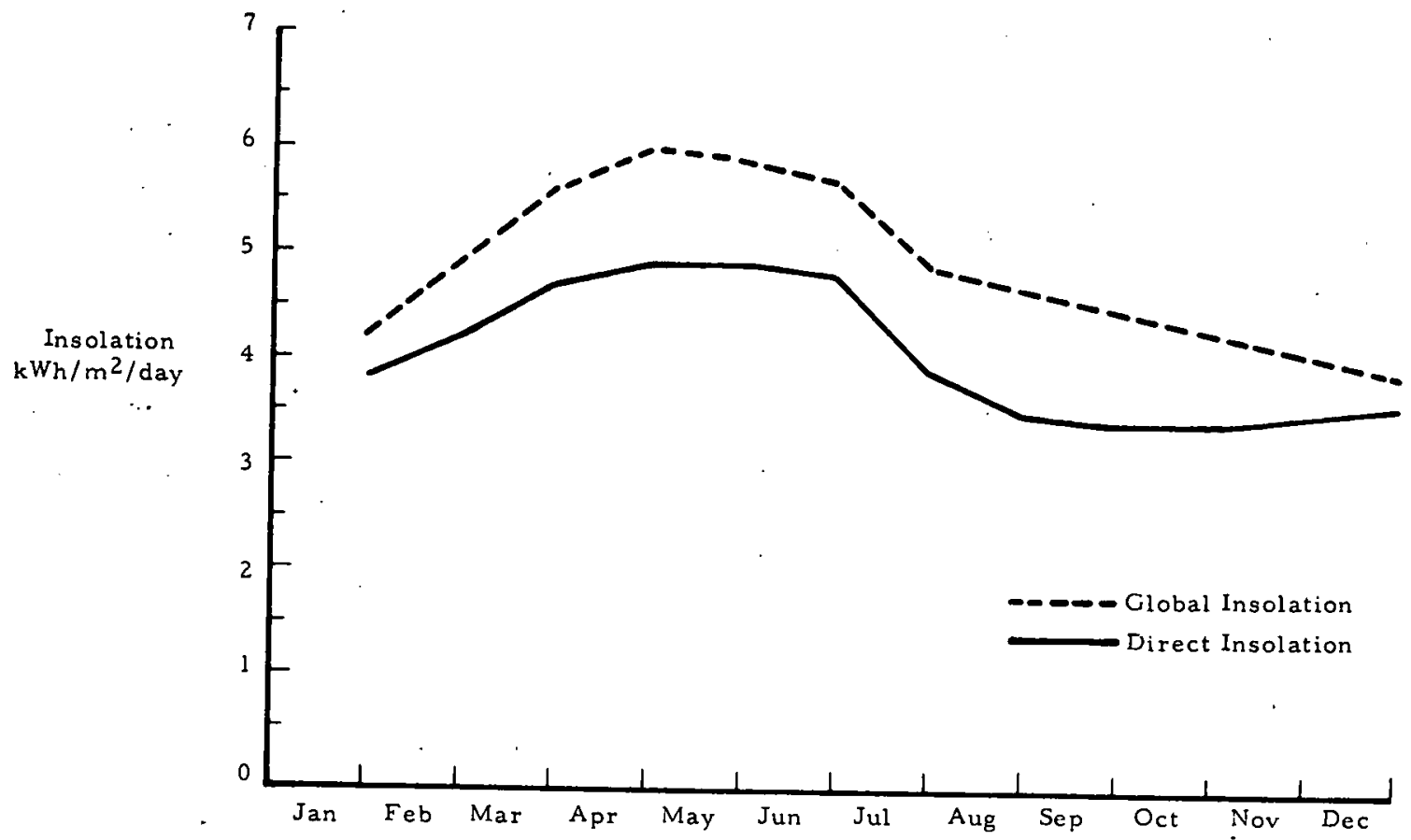

Figure 5-3. Direct and Global Insolation Estimates for Guam 
4. They do not require conversion from global to direct insolation; and

5. They do not seem to be excessively low.

An uncertainty of at least \pm 20 percent should be used with the Guam insolation values reported here.

If a decision were made at a later date to give serious consideration to an experimental solar thermal power system at Guam, work should be conducted to examine cloud cover and sunshine correlations in more deta1l, using the large data base which exists for the United States.

\subsection{OPERATIONAL CONSIDERATIONS}

An undefined portion of the power produced by the Northwest Guam Alr Force Base diesel generators $1 s$ used by an A1r Force satellite traoking station located at the Base (see Figure 5-2). This station tracks' satellites, which w11l normally pass within sight of the station In a north-south direction in orbits which can be anywhere from the eastern to the western horizon. Tracking can occur at any hour of the day or night and each pass of the satell1te must be tracked. Power is provided by one of the four diesel generators located at NGAFB, with a 20 $\mathrm{MW}_{e}$ gas turbine belng available for backup power.

If the NGAFB were selected as a site for an experimental small solar thermal power system, the simplest approach would be to Install the solar system with no or minimal storage, continuing to use the diesel generators for power whenever the insolation level dropped below an acceptable value. Since a diesel generator can be turned on and off very eas1ly, the jolnt use of the solar and diesel systems would provide a simple experimental source of solar thermal power. The solar 
collectors. would have to be located on a north-south line with respect to the station antennas in order to prevent "shadowing" of the antennas when they are tracking satellites close to the eastern or western horizons, where the contact time is very short. The collectors should be located south of the tracking antennas to preclude the antennas from shadowing the collectors from the sun. Concern had been expressed by some Aerospace Corporation personnel that a potential multipath interference problem with the tracking antennas would be generated if the solar collectors were located anywhere in the general vicinity of the tracking antennas. The problem would arise as the result of electromagnetic radiation from the satellite being reflected with slightly different phasing by each of the solar collectors due to the different relative positions of the collectors, the satellite, and the antennas. The resulting radiation collected by the antennas would then be distorted as a result of the incoherent, scattered radiation. Subsequent discussions with Aerospace Corporation specialists in satellite tracking operations indicated that other satellite tracking stations are operating with multiple antennas without any interference' problems and that no interference problems should be expected to arise as a result of co-locating the solar collectors in the vicinity of the tracking station. These specialists did, however, identify the need to locate the solar collector field in the north-south direction.

An approximate idea of the size of the solar collector field can be established as follows. Assume that the small solar thermal power system is to have a generating capacity of $500 \mathrm{~kW}$, the capacity of the largest of the four diesel generators at NGAFB. Assume that the collectors wilj. be parabolic dishes with either a steam or electric transport system. Using JPL data (Reference 3) on these types of solar thermal power systems, the overall system efficiency should range from about 19 to 23 percent for dish-steam and dish-Stirling systems. JPL technology efforts related to small solar thermal power systems are 
examining point focusing collectors with diameters in the 10-meter range. For purposes of providing parametric data on the size of the collector field, system efficiency will be varied from 16 to 24 percent and collector diameter varied from 30 to 36 feet to include the actual design values expected of these two variables. The annualized average dally direct insolation of $4.06 \mathrm{kWh} / \mathrm{m}^{2} /$ day on Guam is equivalent to an average flux of $0.338 \mathrm{~kW} / \mathrm{m}^{2} / \mathrm{hr}$. Table $5-2$ shows the generating capacity of an individual parabolic dish collector with system efficiencies equivalent to near-term and far-term power conversion systems of interest for this study. The table also indicates the number of collectors required to generate $500 \mathrm{~kW}_{\mathrm{e}}$ with the different performance characteristics.

Table 5-2. Collector Generating Capacity as a Function of Efficiency and Collector Diameter

\begin{tabular}{|c|c|c|r|r|r|r|}
\hline \multirow{2}{*}{$\begin{array}{c}\text { Systern } \\
\text { Efficiency }\end{array}$} & \multicolumn{3}{|c|}{ Generating Capacity $(\mathrm{kWe})$} & \multicolumn{3}{c|}{ No. of Units/500 kWe } \\
\cline { 2 - 7 } & \multicolumn{3}{|c|}{ Diameter } & \multicolumn{3}{c|}{ Diameter } \\
\cline { 2 - 7 } & $30 \mathrm{Ft}$ & 10 Meters & $36 \mathrm{Ft}$ & $30 \mathrm{Ft}$ & 10 Meters & $36 \mathrm{Ft}$ \\
\hline 0.16 & 3.55 & 4.24 & 5.11 & 141 & 118 & 99 \\
0.18 & 3.99 & 4.77 & 5.75 & 126 & 105 & 87 \\
0.20 & 4.43 & 5.30 & 6.39 & 113 & 95 & 79 \\
0.22 & 4.88 & 5.84 & 7.03 & 103 & 86 & 72 \\
0.24 & 5.32 & 6.37 & 7.67 & 94 & 79 & 66 \\
\hline
\end{tabular}

If an overall solar thermal power system efficiency of 0.20 , which is a relatively high performance system, is selected for the experimental system, a single parabolic dish with a 10 -meter diameter will be capable of generating $5.30 \mathrm{~kW}_{\mathrm{e}}$. Ninety-five of the collectors will be required to achieve a generating capacity of $500 \mathrm{~kW}_{e} \cdot$ With a separation 
distance of 50 feet, center-to-center, between parabolic dishes, a 12 by 8 collector field geometry would extend approximately 550 feet in a north-south direction and 350 feet in an east-west direction. No attempt has been made to optimize the collector field geometry by minimizing the cost of the installation. The 50 foot separation distance appears more than adequate to prevent shadowing of one collector by an adjacent collector since, at a latitude of $13^{\circ} \mathrm{N}$, no collector will be depressed more than 36 degrees from the vertical.

There are two tracking antennas at the satellite tracking station. The primary antenna is 60 feet in diameter, and is mounted on a 15 foot high pedestal inside of a radome. The second antenna, which is approximately 47 feet in diameter, is located slightly to the northwest of the primary antenna. The location of the tracking station is shown in Figure 5.-2. Since the solar collectors would be located primarily on a north-south line with respect to the antennas, the northern edge of the collector field could be as close as 200 feet from the antennas-without reducing the satellite contact time by more than 10 percent for satellites passing directly overhead. Contact times for satellites passing east or west of the station would be unaffected by the collector field.

The area to the south of the satellite tracking station has reverted to its natural state (jungle) since the map shown in Figure 5-2 was prepared. Thus, installation of a solar thermal power station at NGAFB would require clearing the area south of the tracking station in order to have a clear field of view from the solar collectors to the sun.

\section{$5.3 \quad$ FUTURE ACTIVITY}

Because the insolation at Guam turned out to be..poorer than anticipated when the study of the feasibility of an experimental. DOD 
solar thermal power plant was initiated, work is now underway to accumulate sufficient data to determine the direct solar insolation at Ramey Air Force Base in Puerto Rico and at Guantanamo Navy Base in Cuba. Both bases have their own generating plants, although the Ramey units are not the primary power for the base. In the case of Guantanamo, the base generator does provide primary power for the base. Should the insolation data appear promising, the work on this task would be completed with a determination of the siting feasibility of a solar thermal power plant at the $\operatorname{base}(s)$. 


\section{ALASKA EXPERIMENT}

This section discusses the results of a brief study into the feasibility of conducting an Alaskan solar thermal power system experiment. The original impetus leading to the study is described, climatological information is reviewed, and some guide lines on solar applications in Al.aska are disoussed.

\section{$6.1 \quad$ BACKGROUND}

Alaska is not normally considered in disoussions relating to solar energy. The state tends to be regarded as cold and remote, with poor to non-existent insolation. During the early part of this study, The Aerospace Corporation examined potential applications for solar-powered eleotrioal generation systems. The a priori assumption was made that the southern and southwestern areas of the U.S. would prove to be the optimum looations for solar applications. However, developments during that evaluation, which are desoribed next, led to the unantiolpated examination of Alaska as a potent1al market.

In considering potential users of small solar thermal electrical plants, one group stood out almost immediately, namely, small electrically-1solated communities generating their own electrical power. Hundreds of these communities, operating small inefficlent plants 30 to 35 years old (many requiring now-unavallable natural gas), were in need of replacement units. These communities also had the option of an interconnection with major power grids and the purchase of power from larger, modern, and more efficient generating stations.

An investigation into electrically isolated communities in the 48 contiguous states (for which data were avallable) 1dentified 244 such communities in 1968. However, unpublished data revealed that the 
number had fallen to 70 by early 1976, a decline which is expected to continue for three reasons: (1) it is the policy of the Federal Power Commission (now the Federal Energy Regulatory Commission); (2). the 48 states are sufficiently developed that interconnection is economically feasible and; (3) small replacement units could be expensive, less efficient, and require politically undesirable bond issues.

6.2

\section{ALASKA AND ITS CONSTRAINTS}

From the above discussion, it can be seen that electrically isolated communities are essentially non-existent in the continental U.S. but this is not true in Alaska. Alaska is comparable in size to the combined states of Arizona, New Mexico, Texas, and Oklahoma, having an area of 586;000 square miles, a population of only 400,000, and latitudes ranging from 52 to 71 degrees North.

The characteristics of the insolation in Alaska are considerably different from the insolation in the southwestern U.S., but not necessarily inconsistent with solar applications. Figure 6-1 compares the number of hours of daylight in Albuquerque with that of mid-Alaska (Fairbanks) and the extreme north at Barrow. Note that the

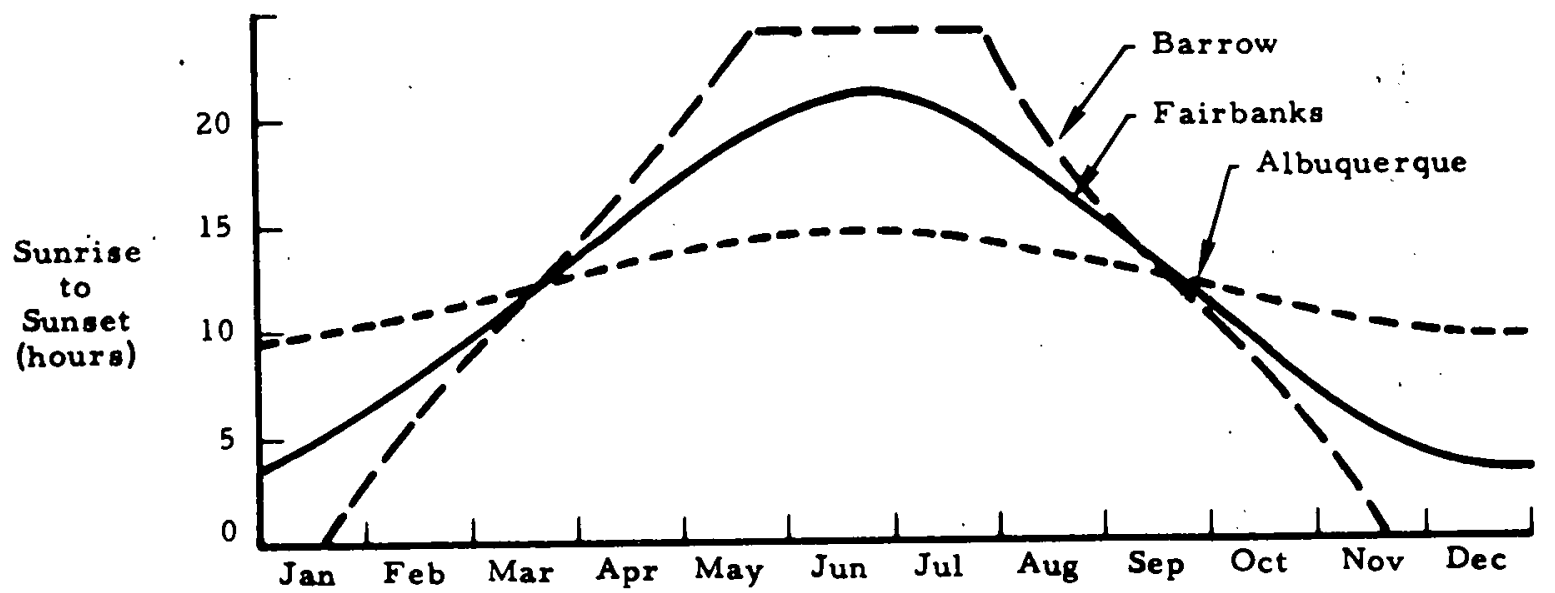

Figure 6-1. Hours of Daylight 
summer months in. Alaska experience substantially longer days than in Albuquerque and look promising for solar use. During the winter months, however, daylight hours, in Alaska are reduced to very brief periods. Therefore, any Alaskan applications would be restricted to late Spring, Summer and early. Fall.

The potential solar. sites in Alaska are constrained by several considerations, primarily. weather...A substantial amount of the population is concentrated along the central portion of the southern coast south of Anchorage, and in the southeastern tail of Alaska extending from Juneau to Ketchikan. Hydroelectric plants are particularly attractive in these regions, however, and the southern coast experiences considerable cloudiness throughout the year.

The western coast from Kotzebue south to Bethel and the Alaska Peninsula extending out along the Aleutian chain also are overcast and cloudy much of the year. Several sites in this region are being considered for wind power, however.

The extreme north, around Barrow, has a plentiful supply of natural gas for power generation. And, in the center of the state, around Fairbanks, large power plants currently exist which would not benefit substantially from solar augmentation.

The seasonal demand curves also tend to argue against summer solar power, particularly in those regions such as Anchorage and Fairbanks which have large baseload plants in place. Peak loads at most sites occur during the winter months when insolation is low and people spend more time indoors. Therefore, any community large enough to support a plant sufficient to meet winter needs economically will have a surplus capacity during the summer months. 
6.2.1 Rural Interior Alaska

Having excluded the coastal and densely populated areas of Alaska from consideration, there remain dozens of small, widely separated, and isolated communities across the center of the state which cannot benefit from interconnection with large utilities, because of the low demand and long distances involved. These towns pay extremely high prices for electrical power, currentiy ranging from $\$ 0.32$ to $\$ 0.50 / \mathrm{kWh}$. Th1s compares w1th $\$ 0.024$ in Anchorage and $\$ 0.043$ in Juneau and Falrbanks. It is these remote communities which offer the greatest potential for solar use, primarliy in augmenting or replacing diesel generation during the summer months.

The high cost of power in these isolated communities is caused primarily by two factors. First, these towns, with populations of from 100 to 3,000 people, commonly use small inefficient diesel generators for power generation. Second, the fuel for these generators must be shipped during the ice-free season along the coast and on interior rivers. Sometimes, fuel supplies are even delivered by air.

One such community, described in Reference 17, is Napikiak, which consists of 38 houses, 223 people and 23 small generators averaging 3: $\mathrm{kW}_{\mathrm{e}}$ in size. Another is Akiachak, with 320 people, 51 households and f'ilve generators serving 38 of the residences for varying portions of the dlay.

The largest user of power in the typical community is the school, foliowed closely by residences. Together; they consume about 79 percent of the power generated. The residential use rate per home is quite small, averaging about $1,500 \mathrm{kWh}$, which is the amount required to provide only light and refrigeration in each residence. By comparison, the statewide average is about $9,000 \mathrm{kWh}$. Therefore, solar power could 
be used to elther upgrade the town's service, or to allow the diesels to go to standby for backup to the solar system during the well-1lluminated portion of the year.

The largest single electrical supplier to rural areas is the Alaska Village Electric Cooperative (AVEC). AVEC provides power to 48 scattered communities with populations from 100 to 600 . AVEC data Indicate an increasing power use per oustomer, with consumption constrained primarily by the avallable power supply. An AVEC survey estimates that 125 communities presently exist with populations of over 25 people (about 15,000 people total) without an adequate electrical power system.

\subsubsection{Insolation In Central Alaska}

Insolation data are avallable from the U.S. Department of Commerce for a few coastal olties in Alaska, and for Fairbanks in the central interior. Because of cloud cover and other considerations, the central interior appears to be the most viable area for solar applications. Therefore, the Falrbanks data were reduced and are presented in Figures 6-2 and 6-3, with the Albuquerque data included to facilitate comparison.

The estimated upper limit direct normal insolation (DNI) data are given in Figure 6-2. The DNI data, at solar noon, show a broad flat period of several months during which the Falrbanks maximum $(1,054$ watts $/ \mathrm{m}^{2}$ ) closely approximates that of Albuquerque. The lower value is due to the lower sun angle (about 41 degrees maximum) at the higher lat1tudes. Attenuation is thus increased by the sun's longer path length through the atmosphere.

Probably the most meaningful measure of insolation is the integrated value of the DNI over an entire day, as presented in 


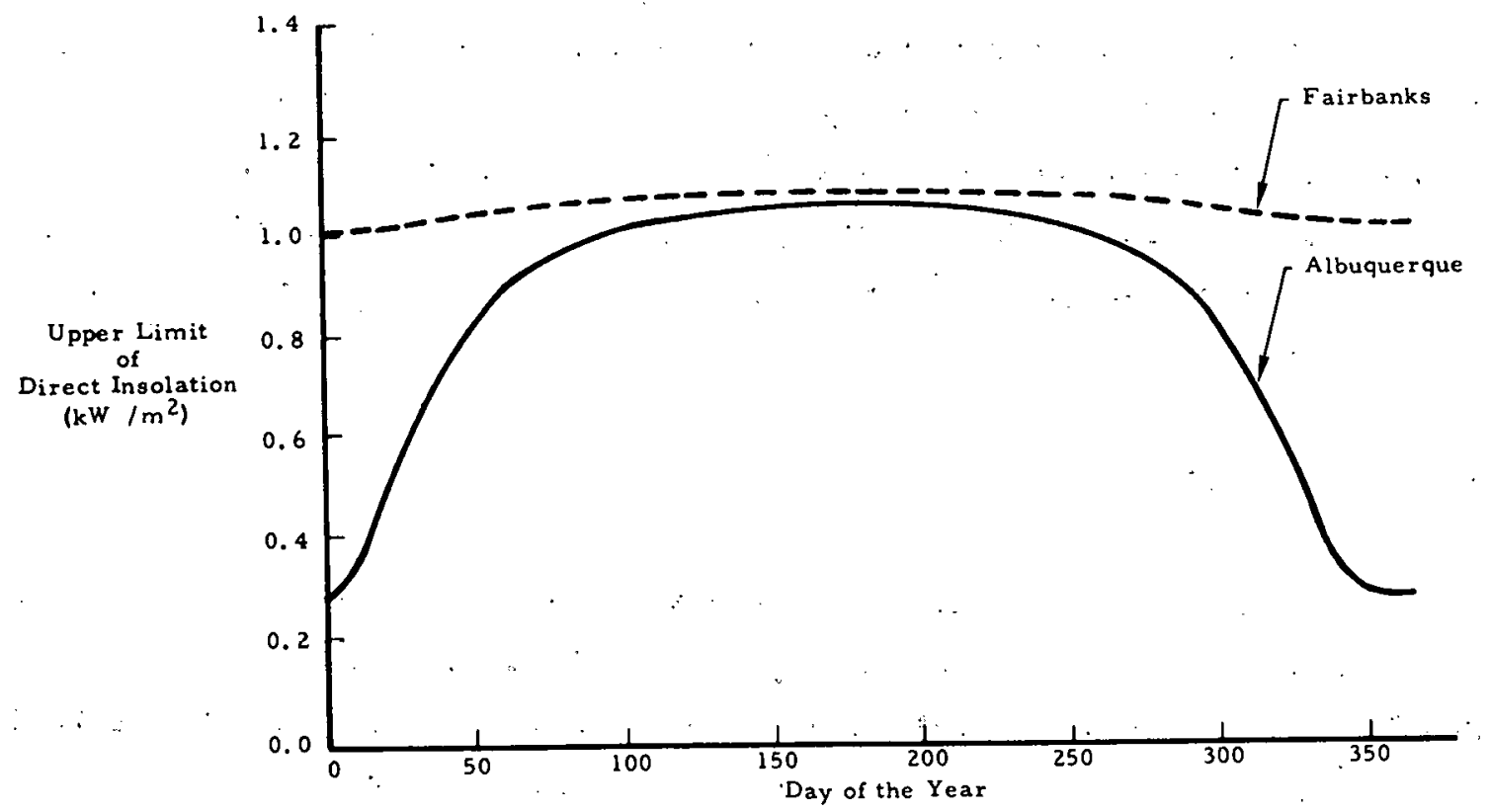

Figure 6-2. Fairbanks and Albuquerque Direct Insolation Upper Limits

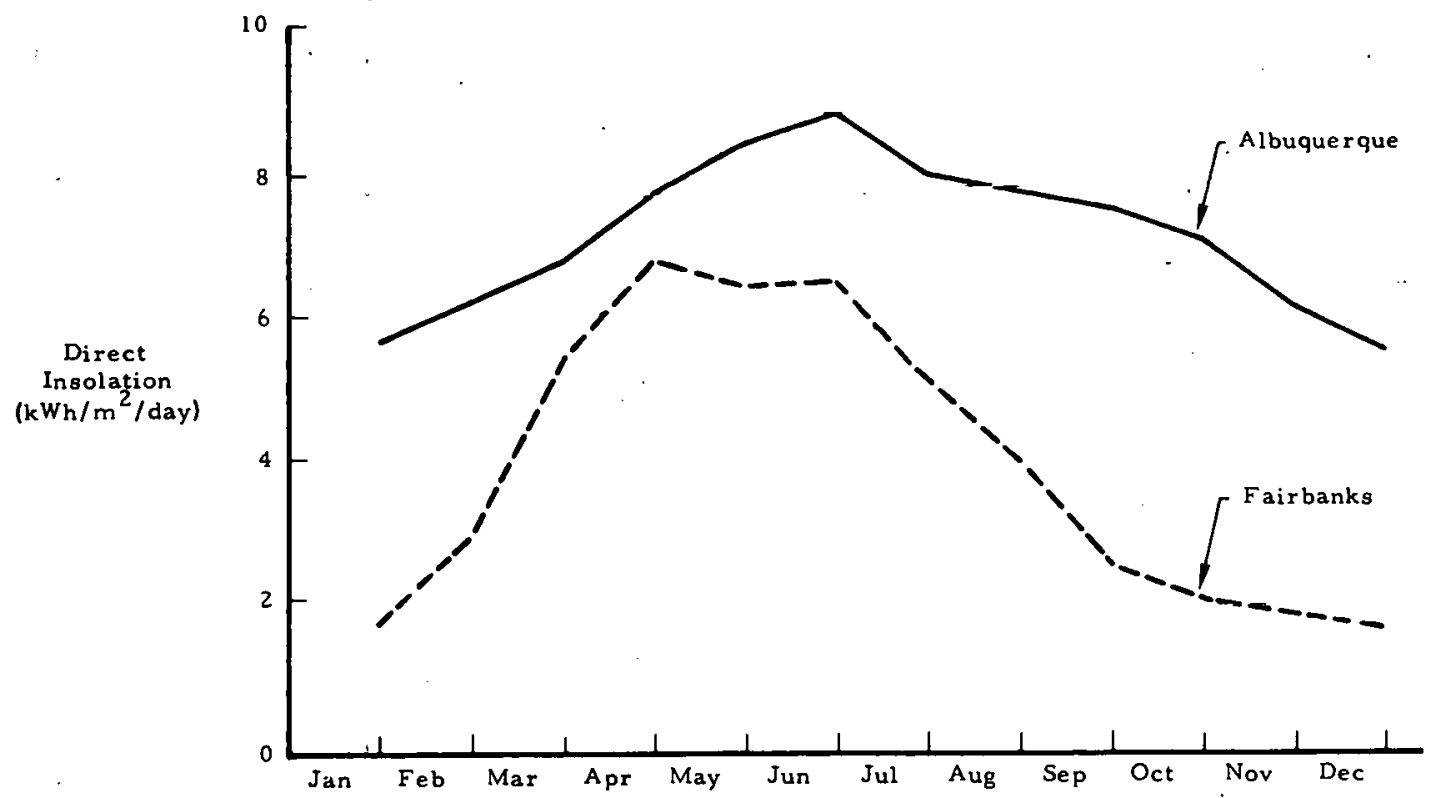

Figure 6-3. Comparison of Albuquerque and Fairbanks Direct Insolation 
Figure 6-3. The data consist of 25-year averages of actual insolation, both at Falrbanks and Albuquerque, for the first day of each month. The Fairbanks daily direct energy value, which includes the effects of atmospheric attenuation and cloud cover, compares favorably with Albuquerque from about March through August. This is the time of year which is suggested as potentially being most viable for solar applications.

\section{$6.3 \quad$ SUMMARY}

If DOE so desired, it appears that an experimental Alaskan solar thermal power plant of several kilowatts capacity could be installed and operated in one of the isolated communities in the central interior of the state. The most. likely location would appear to be either east or west of Fairbanks, perhaps along the Yukon River.

The function of the solar thermal power plant would be to augment or replace the diesel generation requirements during the summer months, thus conserving costly diesel fuel for use during the winter. An alternative application would be the generation of incremental electrical power for use by local industry during the summer months, when productive activity is at a maximum. 


\section{REMOTE APPLICATIONS}

The examination of remote applications, like the examination of DOD applications, stemmed from an attempt to assist JPL in searching for potential applications for their experimental systems. Contacts were made with the Mining and Resources Division of the State of California, the Arlzona Department of Mineral Resources, the Safford (Arizona) Division of Phelps Dodge, and Community Publio Service Company (New Mexico Division) to obtain information about mining operations in the southwestern United States. After acquiring the Information on mining operations, it appeared that, at best, lumbering operations would not represent a very widespread application for small solar thermal power systems because the weather (insolation) is generaliy poorer in the reglons of the western United States where lumbering is carried out. It Is possible, although not too likely because of the lower insolation values in the eastern part of the United States, that there oould be areas in the eastern United States in which solar thermal power systems might be cost-effective.

The development of a commercial mining operation in the southwest appears to follow the general pattern disoussed in this paragraph. As soon as a new mining olaim is worked to determine its commercial potential, a diesel generator is brought in to provide power for the early mining activities. If the mine appears to have commerolal potential, arrangements are made with the local ut1lity system to bring in a transmission 11ne. In Arizona, most new mines will be within 25 miles of a major power line and, in the case of copper mines, the terrain is senerally desert in nature with low $(<1500 \mathrm{ft})$ mountains. It is not diffioult to string transmission ilnes through this type of terrain. In Arizone, the mining company will. negotlate a price for a blook of power which inoludes the amortization of the transmission line cost. In New Mex100, the copper mines are also located relatively close ( $<25 \mathrm{mlles}$ ) 
from a transmission ilne so that it is not difficult to bring in power to a new mine. However, the New Mexico Public Utility Commission requires the mine owner to pay for the transmission line before any power can be brought in. The mining company then negotiates a rate with the utility which reflects the fact that the utility does not incur any major cost in providing power to the mine.

Mining companies try to recover the capital investment in the mine within 6.5 years. To do this, they w1ll operate two shifts a day in the mine and three shifts per day in the smelter. The third mine shift is used for maintenance. The largest cost of a mine during its first few years is interest on the investment. A mine will normally exploit its high grade ore during this period to increase its cash flow: A major mining company will not open a large open pit copper mine unless there appears to be at least a 25-year supply of ore. In view of the limited number of new copper mines under development at any one time, the mining industry's philosophy of amortizing its capital investment quickly, and its around-the-clock operations, it did not seem productive to pursue mining applications any further. 


\section{REFERENCES}

1. . Interim Report on Small Power Systems Study.. Aerospace Technical Report ATR-77(7693-05)-1, The Aerospace Corporation, El Segundo; California (15 January 1978): (DOE Contract EY-76-C-03-1.101).

2. Central Receiver. Solar Thermal Power System, Phase I, VII, Books 1 and 2, Prellminary Report, MDC G 6776, McDonnell Douglas Astronautics Company - West, Huntington Beach, California (May 1977).

3. Projection of Distributed-Collector Solar Thermal Electric Power Plant Economics to Years 1990-2000, Jet Propulsion Laboratory Report DOE/JPL-1060-77/1, Jet Propulsion Laboratory, Pasadena, California (December 1977).

4.:- Electrical World Directory of Electric Utilities, 1976-197.7, 85th Edition, McGraw-H1ll, Inc., New York (1977).

5. . Inventory of Power Plants in the United States, NTIS Report No. PB-269 867, Federal. Energy Administration, Washington, D.C. (June 1977).

6. On the Nature and Distribution of Solar Radiation, Report HCP/T 2552-01; Watt Engineering Ltd., Cedaredge, Colorado (March 1978) (DOE Contract EX-76-C-01-2552).

7. Solar Total Energy Systems Final Technical Summary Report, Volume II, Energy. Use and Price Forecasts, Aerospace Technical Report ATR-78(7692-01)-1, Volume II, The Aerospace Corporation, El Segundo; California (31 March 1978).

8. Steam-Electric Plant Construction Cost and Annual Production Expenses, 24 th Annual Supplement, Federal Power Commission, Washington, D.C. (1971).

9. The Handy-Whitman Index of Public Utility Construction Costs, Bulletins No. 101 and 106, Whitman, Requardt and Associates, Baltimore, Maryland (January 1975 and July 1977).

10. Synthetic Electric Utilities Systems for Evaluating Advanced Technologies, EPRI Report EM-285, . Power Technologies, Inc., Schenectady, N.Y. (February 1977).

11. Performance, Value, and Cost of Solar Thermal Electric Central Receiver Plants Outside of the Southwest, Aerospace Technical Report ATR-78(7689-04)-1, The Aerospace Corporation, El Segundo, California (16 May 1978). 
12. The Cost of Energy from Utility-Owned Solar Electric Systems, A Required Revenue Methodology for ERDA/EPRI Evaluations, ERDA/JPL Report 1012-76/3, .. Jet Propulsion Laboratory, Pasadena, California (June 1976).

13. . Solar Total Energy. Systems Final Technical Summary Report, Volume I, Solar Total Energy Systems Market Penetration, Aerospace Technical Report ATR-78(7692-01)-1, Volume I, The Aerospace Corporation, El Segundo, Cal1fornia (31 March 1978).

14. G.0. Lof, J.A. Duffie, and C.0. Smith, "World Distribution of Solar Radiation", Solar Energy, 10, 27 (1966).

15. R.K. Reed, An Evaluation of Cloud Factors for Estimating Insolation Over the Ocean, NOAA Teohnical Memorandum ERL PMEL-8, National Ooeanographio and Atmospher1o Administration, Rockville, Maryland (September 1976).

16. C.M. Rąndall and M.E. Wh1tson, Jr., Hourly Insolation and Meteorologioal Data Bases Including Improved Direct Insolation Estimates, Aerospace Teohnical Report ATh-78(7592)-1, The Aerospace Corporation, El Sègundo, California (December 1977).

17. Eleotrlo Power in Alaska,. 1976-1995,. A Report for the House Finanoe Committee, Second Session, Ninth Leglslature, State of Alaska, Institute of Soolal and Economio Research, Un1versity of Alaska (August 1976). 